\title{
Shallow water Actiniaria and Corallimorpharia (Cnidaria: Anthozoa) from King George Island, Antarctica
}

\author{
N.P. Sanamyan ${ }^{1}$, K.E. Sanamyan ${ }^{1}$, D. Schories ${ }^{2,3}$ \\ ${ }^{I}$ Kamchatka Branch of Pacific Geographical Institute, Far-Eastern Branch of the Russian Academy \\ of Sciences, Partizanskaya 6, Petropavlovsk-Kamchatsky, 683000, Russia. E-mail: \\ actiniaria@sanamyan.com \\ ${ }^{2}$ Instituto de Ciencias Marinas y Limnológicas, Facultad de Ciencias, Universidad Austral de Chile, \\ Valdivia, Chile. \\ ${ }^{3}$ Faculty of Agricultural and Environmental Sciences, University of Rostock, Justus-von-Liebig- \\ Weg 6, 18059 Rostock, Germany.E-mail:dirk.schories@uni-rostock.de
}

ABSTRACT: Antarctic sea anemones, with few exceptions, are known mainly from dredged or trawled samples while the shallow water anemone fauna of this region is poorly known. In the present paper, we present records of 10 species of sea anemones collected and photographed in situ on diver accessible depths (down to $40 \mathrm{~m}$ ) on King George Island. Three species, Edwardsia inachi sp.n., Armactinia antarctica gen.n. sp.n. and Corallimorphus karinae sp.n. are described as new. The remaining species are briefly described and discussed. Descriptions include new data on nematocysts and shape of spermatozoa.

How to cite this article: Sanamyan N.P., Sanamyan K.E., Schories D. 2015. Shallow water Actiniaria and Corallimorpharia (Cnidaria: Anthozoa) from King George Island, Antarctica // Invert. Zool. Vol.12. No.1. P.1-51.

KEY WORDS: sea anemones, actinians, Actiniaria, Corallimorpharia, Antarctic.

\section{Мелководные Actiniaria и Corallimorpharia (Cnidaria: Anthozoa) из района острова Короля Георга, Антарктика}

\section{Н.П. Санамян ${ }^{1}$, К.Э. Санамян ${ }^{1}$, Д. Шорес ${ }^{2,3}$}

\footnotetext{
${ }^{1}$ Камчатский филиал Тихоокеанского института географии ДВО РАН, ул. Партизанская 6, Петропавловск-Камчатский 683000 Россия, e-mail: actiniaria@sanamyan.com

${ }^{2}$ Институт морских и лимнологических наук, факультет естественных наук, Южный чилийский университет, Вальдивия, Чили.

${ }_{3}^{3}$ Факультет сельского хозяйства и наук об окружающей среде, Университет Ростока, Justus-von-Liebig-Weg 6, 18059 Росток, Германия, e-mail: dirk.schories@uni-rostock.de
}

РЕЗЮМЕ: Антарктические морские анемоны, за немногими исключениями, известны в основном по образцам, собранным с помощью драг и тралов, а мелководная фауна морских анемон этого региона плохо известна. В настоящей статье мы даем информацию о 10 видах морских анемон, собранных и сфотографированных in situ на доступных дайверам глубинах (до 40 м) в районе острова Короля Георга. Три вида, Edwardsia inachi sp.n., Armactinia antarctica gen.n. sp.n. и Corallimorphus karinae sp.n. описаны как новые. Оставшиеся виды кратко описаны и обсуждены. Описания включают новые данные по нематоцистам и форме сперматозоидов.

Как цитировать эту статью: Sanamyan N.P., Sanamyan K.E., Schories D. 2015. Shallow water Actiniaria and Corallimorpharia (Cnidaria: Anthozoa) from King George Island, Antarctica // Invert. Zool. Vol.12. No.1. P.1-51.

КЛЮЧЕВЫЕ СЛОВА: морские анемоны, актинии, Actiniaria, Corallimorpharia, Антарктика. 


\section{Introduction}

Antarctic sea anemones have a long history of investigation. Almost all previous works on sea anemones from the Antarctic (e.g. Stephenson, 1918; Carlgren, 1927, 1939; Dunn, 1983; Fautin, 1984; Rodríguez, López-González, 2013) were based on trawled or dredged specimens. We present the first account of 10 species of Antarctic sea anemones based on shallow water samples obtained by SCUBA divers and accompanied with underwater photographs of undisturbed living specimens in their natural environment. In recent years high quality photographs of sea anemones in their natural environment become a very important part of species descriptions and significantly improved our understanding of these creatures (see Sanamyan et al., 2013). Despite the long history of investigation our knowledge of many species of Antarctic sea anemones has significant gaps, the taxonomic position and synonymy of many species is not well established and even morphological information provided by different authors on the same species may differ in significant details. Our knowledge on the species diversity, at least in shallow water, also appears to be incomplete - among 10 species identified in the present material three are described as new species, one of which belongs to a new genus.

\section{Material and methods}

Several actiniarian samples from Fildes (Maxwell) Bay, King George Island, South Shetland Islands, were taken in the frame of a monitoring project financed by the Chilean Antarctic Institute (Instituto Antárctico Chileno, INACH). The project used a diver-towed Underwater GPS coupled with image analyses to assess the species distribution along a depth gradient with an error range inferior to $10 \mathrm{~m}$ (Schories, Niedzwiedz, 2012). All samples of sea anemones were taken by scuba divers and stored in individual bags under water to facilitate analysis of the quantitative images taken along predefined GPS routes down to $40 \mathrm{~m}$ depth. GPS routes included sheltered and exposed sites with a large variety of substrate types. Inclination varied from moderate slope to vertical. Only locations directly in front of glaciers were not sampled.
Samples were collected at King George Island (KGI) $\left(62^{\circ} 02^{\prime} \mathrm{S}, 58^{\circ} 21^{\prime} \mathrm{W}\right)$, South Shetland islands, situated at $c a .120 \mathrm{~km}$ off the northern coast of the Antarctic Peninsula (Fig. 1). Actiniarians were sampled at five stations at Fildes Bay (FB), a $16 \mathrm{~km}$ long bay, opened in south-east direction, and lying between King George and Nelson Islands. The Chilean Antarctic research base Escudero, from where diving operations were realized, is located at the innermost, eastern part of the bay. The sampling stations can be shortly described as follows:

1) Nebles Point (PNS, $62^{\circ} 11^{\prime} 18^{\prime \prime} \mathrm{S}, 58^{\circ} 52^{\prime}$ $20^{\prime \prime} \mathrm{W}$ ): vertical rock down to $15 \mathrm{~m}$, pebbles and boulders in the deepest parts;

2) Escudero (ESC, $62^{\circ} 12^{\prime} 05^{\prime \prime} \mathrm{S}, 58^{\circ} 57^{\prime} 37^{\prime \prime}$ $\mathrm{W})$ : pebbles and boulders down to $8 \mathrm{~m}$ depth, then slight slope down to $25 \mathrm{~m}$, dominated by soft bottom;

3) SHOA rock ( $\mathrm{SHO}, 62^{\circ} 12^{\prime} 12^{\prime \prime} \mathrm{S}, 58^{\circ} 56^{\prime} 37^{\prime \prime}$ $\mathrm{W})$ : small, vertical rock, down to $8 \mathrm{~m}$ depth, then with moderate slope down to $40 \mathrm{~m}$, bottom with pebbles and rocks, becoming mainly soft below $40 \mathrm{~m}$;

4) Ardley Island (ARD, $62^{\circ} 12^{\prime} 35^{\prime \prime} \mathrm{S}, 58^{\circ} 55^{\prime}$ $\left.33^{\prime \prime} \mathrm{W}\right)$ : bottom dominated by cobbles and boulders, moderate slope;

5) Ras Tu (RAS, 62 $13^{\prime} 17^{\prime \prime} \mathrm{S}, 58^{\circ} 53^{\prime} 13^{\prime \prime}$ W): solitary, nearly vertical rock with more than $80 \mathrm{~m}$ depth, about $4.4 \mathrm{~km}$ SE from Escudero.

Macroalgae were dominant down to $30 \mathrm{~m}$ at all stations except Escudero.

The specimens were fixed with formaldehyde; some were transferred to $70 \%$ ethanol for long term storage. For the methods used to prepare histological sections and method to stain and examine cnidae on sections see Sanamyan et al. (2013). Cnidae terminology follows Sanamyan et al. (2012). Cnidae were measured according the method of Hand (1954). The reasons why we prefer this method are described by Sanamyan \& Sanamyan (2012). Type material is stored in the Zoological Institute (ZIN), St. Petersbourg and Kamchatka Branch of the Pacific Geographical Institute (KBPGI). Additional material was received from American Museum of Natural History (AMNH), and Museum of Zoology, University of Bergen (ZMBN). 


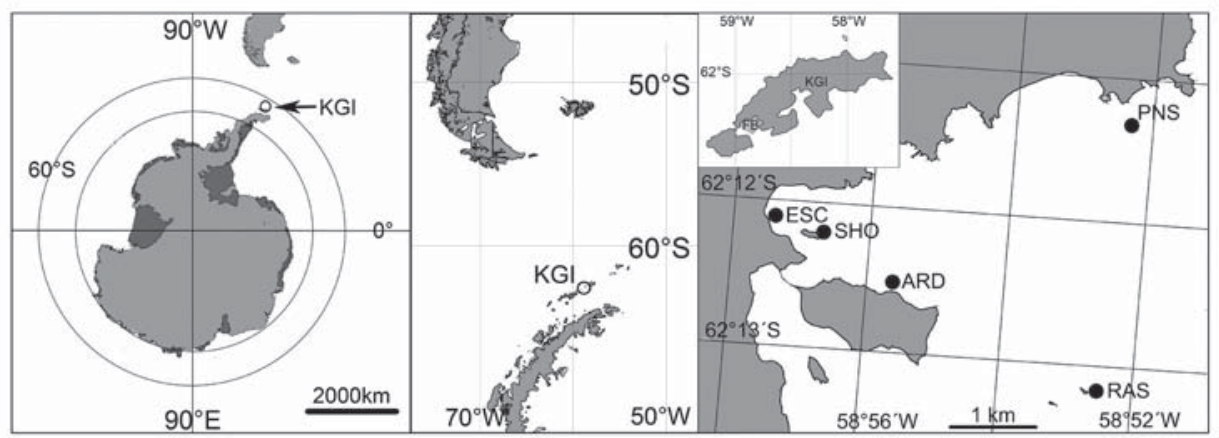

Fig. 1. Map of study area with the position of sampling stations (for abbreviations see text).

Рис. 1. Карта исследованного региона с обозначением станций, где производился отбор проб (обозначения см. в тексте).

\section{Descriptions}

\section{Order Actiniaria}

Family Edwardsiidae Andres, 1881

\section{Edwardsia inachi sp.n.}

Table 1; Figs. 2-5, 31A.

Material examined. Holotype: ZIN 11330, ESC, 2011 02-18-(02), 10 m. Paratypes: ZIN 11331, ESC, 2011-0218-(02), 10 m, 2 specimens; ZIN 11332, ESC, 2011-0121-(02), 7 m, 1 specimen; KBPGI 428/1, ESC, 2010-0208-(38), 8 m, 1 specimen; KBPGI 429/2, ESC, 2011-0123-(01), 10 m, 2 specimens; KBPGI 430/3, ESC, 2011-0123-(02), 10 m, 1 specimen; KBPGI 431/4, ESC, 2011-0123-(09), 10 m, 1 specimen.

Description. External anatomy. The specimens are in a good condition and perfectly preserved, although the distal part of the body of some is contracted and the tentacles are not always visible. Preserved specimens are large, cylindrical, range $48-80 \mathrm{~mm}$ length and 7-12 $\mathrm{mm}$ in diameter and have a rather "robust" appearance. Some of them are straight, other curved due to unequal contraction of strong musculature (Fig. 2C).

The column is divisible into five regions: physa, proximal scapus, distal scapus, scapulus and capitulum. The physa is small, its diameter usually significantly smaller than the diameter of the column (Fig. 2E), non ampullaceous, flattened or, in some specimens, invaginated and not visible externally. It has no nemathybomes or periderm and has one central perforation (Figs. 3D, E).

The scapus is divisible into two distinct zones. The longer (40-62 $\mathrm{mm})$ and more robust proximal part of the scapus is densely covered with large crowded papillae (Fig. 2F) containing nemathybomes. The papillae are arranged into eight wide bands corresponding to eight macrocoels, these bands are separated by thin bare lines corresponding to mesenterial insertions (Figs. 2C, E). The smaller $(9-22 \mathrm{~mm}$ ) distal part of the scapus has no papillae but is covered by a thin periderm (Fig. 2D).

The scapulus is $2-11 \mathrm{~mm}$ depending on the degree of contraction. In most preserved specimens it is invaginated and not visible externally. The scapulus is not covered by periderm and has eight prominent mesogloeal thickenings (Fig. 2D). The capitulum is a very short thin-walled region located between the bases of the tentacles and the scapulus (Fig. 2D).

The number of the tentacles usually varies from 28 to 36 (but only 23 counted in one specimen). The length of the tentacles in preserved specimens is up to $4 \mathrm{~mm}$, in living specimens the tentacles are up to three or four times longer than the diameter of the oral disc (Figs. 2A, B). They are capable to invaginate into itself as fingers of glove.

The colour of the preserved specimens is dirty brown or grayish. In living specimens (Figs. 2A, B) the tentacles are colourless without any pigment marks. Oral disc is dark, grayish-brown, with whitish radial lines corresponding to the insertions of the mesenteries. The capitulum is white with translucent mesenterial insertions.

Internal anatomy and histology. The ectoderm of the body is about $10-50 \mu \mathrm{m}$ thick, the mesogloea is about $50 \mu \mathrm{m}$, the endoderm 

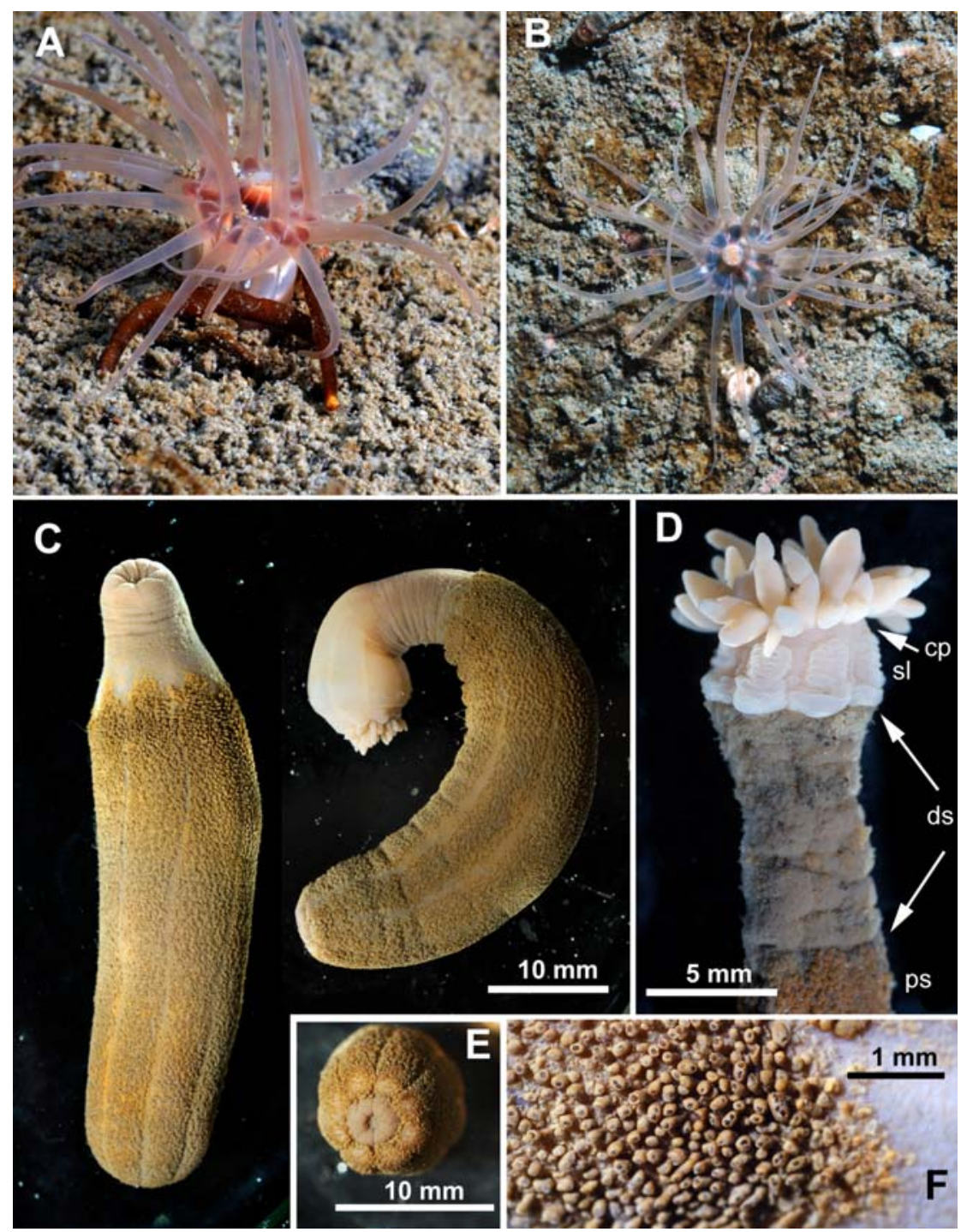

Fig. 2. Edwardsia inachi sp.n. A-B - living specimens with expanded crown of tentacles; C - preserved specimens, note bare (lacking papillae) distal part of the scapus; D - distal end of preserved specimen (KBPGI 431/4) showing distal part of the scapus (covered by grayish periderm but without papillae), pale scapulus with prominent mesogloeal thickenings and a short capitulum just below the bases of the tentacles; E - aboral end of the body to show small physa; F - enlarged view of mesogloeal papillae, note dark cuticular caps on the top of many papillae.

Abbreviations: $\mathrm{cp}$ - capitulum; ds - distal scapus; $\mathrm{ps}$ - proximal scapus; sl — scapulus.

Рис. 2. Edwardsia inachi sp.n. А-B - живые экземпляры с расправленными щупальцами; С фиксированные экземпляры, видна лишенная папилл дистальная часть скапуса; D - дистальный конец фиксированного экземпляра (KBPGI 431/4), видна дистальная часть скапуса (лишенная папилл и покрытая серой перидермой), светлый скапулюс с мезоглеальными утолщениями и короткий капитулюм непосредственно под основаниями щупалец; $\mathrm{E}-$ аборальный конец тела с маленькой физой; F - мезоглеальные папиллы крупным планом, видна темная кутикулярная "шапочка" на концах многих папилл.

Обозначения: cp - капитулюм; ds - дистальный скапус; ps - проксимальный скапус; sl — скапулюс. 
Table 1. Size ranges (length $\times$ width, in microns) and distribution of cnidae of Edwardsia inachi sp.n. (measured in two specimens). Letters in brackets correspond to letters in Fig. 5.

Таблица 1. Размеры (длина $×$ ширина, в микронах) и распределение стрекательных капсул Edwardsia inachi sp.n. (по двум экземплярам). Буквы в скобках соответствуют буквам на рис. 5.

\begin{tabular}{|l|c|c|}
\hline Body region & Cnidae & Size ranges $(\mu \mathrm{m})$ \\
\hline Physa & (A) basitrichs (common) & $26-32 \times 2.5-4$ \\
\hline Nemathybomes & (B) basitrichs & $27-45 \times 3.5-5.5$ \\
\hline Distal scapus & (C) basitrichs (common) & $23-28 \times 3-3.5$ \\
\hline Scapulus & (D) basitrichs (numerous) & $17-26 \times 2.5-3$ \\
\hline \multirow{3}{*}{ Tentacles } & (E) gracile spirocysts (numerous) & $15-36 \times 2-3.5$ \\
& (F) robust spirocysts (numerous) & $20-40 \times 3.5-5.5$ \\
\hline \multirow{3}{*}{ Actinopharynx } & (G) basitrichs (numerous) & $25-35 \times 2-2.5$ \\
& (H) basitrichs (common) & $21-28 \times 2.5-3$ \\
\hline \multirow{2}{*}{ Filaments } & (I) basitrichs (numerous) & $31-47 \times 3.5-4.5$ \\
& (J) p-mastigophores A (few) & $27-29 \times 5-6$ \\
\hline
\end{tabular}

100-200 $\mu \mathrm{m}$. The structure of the ectoderm of the physa and scapus is similar. On histological sections the physa can be distinguished only by the absence of the periderm and nemathybomes (Fig. 3D). The mesogloeal papillae on the scapus are 200-300 $\mu \mathrm{m}$ long and about $100 \mu \mathrm{m}$ diameter. They are covered by firm cuticle which forms a dark cap on the top (Fig. 2F). As revealed on histological sections the cuticle is multistratified, composed of numerous thin sheets closely adhered to each other and forming a thick solid layer on the sides and the top of each papilla (Fig. 3F). Each papilla contains a long nemathybome which occupies almost the whole space inside the papilla and contains about 30 nematocysts concentrated on the top. In the ectoderm of the distal smooth part of the scapus (which lacks mesogloeal papillae) all nematocysts are arranged in round compact structures 50$66 \mu \mathrm{m}$ diameter resembling nemathybomes but not immersed into mesogloea (Fig. 3G). The distance between these structures is about the same as the distance between the papillae in the proximal part of the scapus (about 200 $\mu \mathrm{m})$. Nematocysts in these structures are smaller and less numerous (about 20) than nematocysts in the nemathybomes in papillae (see Table 1, Fig. 5).

The columnal circular endodermal muscles are very strong. Radial muscles of oral disc and longitudinal muscles of the tentacles are ectodermal (Fig. 3H).

The actinopharynx is rather short, with one discernible siphonoglyph. Eight macrocnemes are present along the whole length of the body and small microcnemes in the capitulum only, at the bases of the tentacles. The arrangement of microcnemes in two sectioned specimens with 28 and 30 tentacles is shown on Fig. 4.

Retractor muscles are large, with a large pennon and with about $30-35$ muscle processes, most of which are branched (Figs. 3A, B). Parietal muscles are well developed, oval or rhomboid on transverse sections, with many branched lamellae which are shorter on inner and outer parts (Fig. 3C). Parietal muscle fibers are expanded on the body wall.

Among three specimens sectioned in the reproductive region, two were male and one had both male and female gametes. The diameter of eggs is $600-700 \mu \mathrm{m}$. The spermatozoa are tip headed, radially symmetrical, with large mitochondrial complex, the head is about $4 \times 2 \mu \mathrm{m}$ (Fig. 31A). The trilobate filaments are rather short and located on the macrocnemes just below the actinopharynx. The unilobate filaments run along the whole rest length of the macrocnemes.

Cnidom. Robust and gracile spirocysts, basitrichs, p-mastigophores A (see Fig. 5 and Table 1 for size ranges and distribution). Nemathybomes contain one type of nematocysts. 


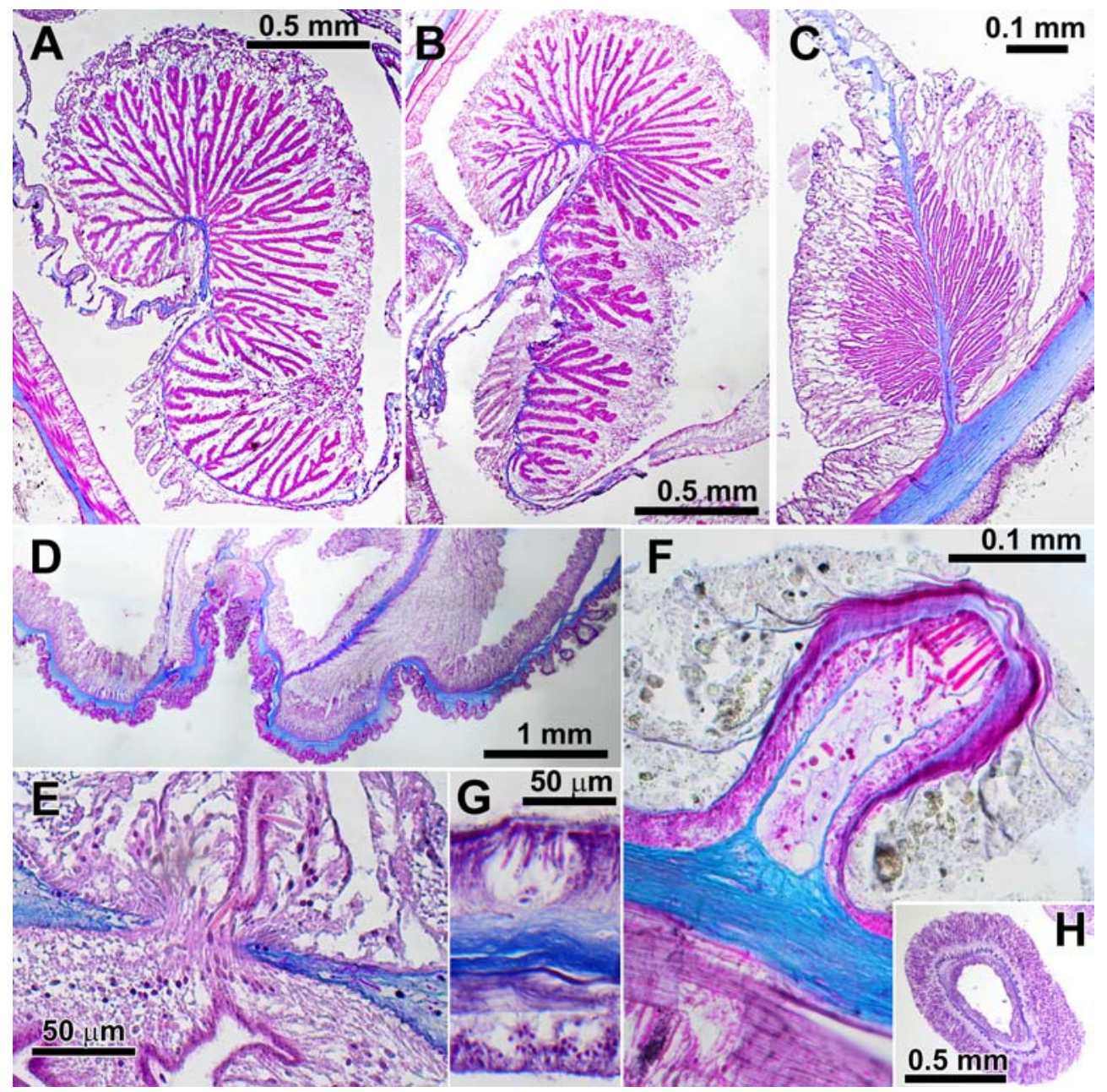

Fig. 3. Edwardsia inachi sp.n., histological sections. A-B - general appearance of two retractors on transverse sections; $\mathrm{C}$ - parietal muscle; D - longitudinal section through aboral end of the body; E enlarged photo of the same section to show aperture in the center of the physa; F - mesogloeal papilla on the scapus containing nemathybome, note thick deeply stained cuticular covering and thin sheets coming off from the sides of papilla; $\mathrm{G}$ - a cluster of nematocysts in the ectoderm of the distal end of the scapus resembling nemathybome, note the absence of mesogloeal covering around it; $\mathrm{H}$ - transverse section of the tentacle showing ectodermal longitudinal muscles.

Рис. 3. Edwardsia inachi sp.n., гистологические срезы. А-В - общий вид двух ретракторов на поперечных срезах; C - париетальный мускул; D - продольный срез через аборальный конец тела; $\mathrm{E}$ - увеличенная фотография этого же региона, видно отверстие в центре физы; F - мезоглеальная папилла на скапусе, содержащая нематибому, видно толстое сильноокрашенное кутикулярное покрытие и тонкие листки кутикулы, отходящие от боковых сторон папиллы; $\mathrm{G}$ - группа нематоцист в эктодерме дистального конца скапуса, напоминающая нематибому, но не погруженная в мезоглею; H - поперечный срез через щупальце, показывающий продольную эктодермальную мускулатуру.

Distribution and habitat. The species is known only from King George Island, Antarctica. It was exclusively found burrowed in muddy sediments with only oral disc and the tentacles exposed on surface. By disturbance the animal retreated com- pletely several centimeters into the sediment. Samples were taken between 7-10 $\mathrm{m}$ depth, but the species was present down to $15 \mathrm{~m}$. Species density was low $\left(<1\right.$ ind. $\left.25 \mathrm{~m}^{2}\right)$, but individuals were frequently seen by the divers. 

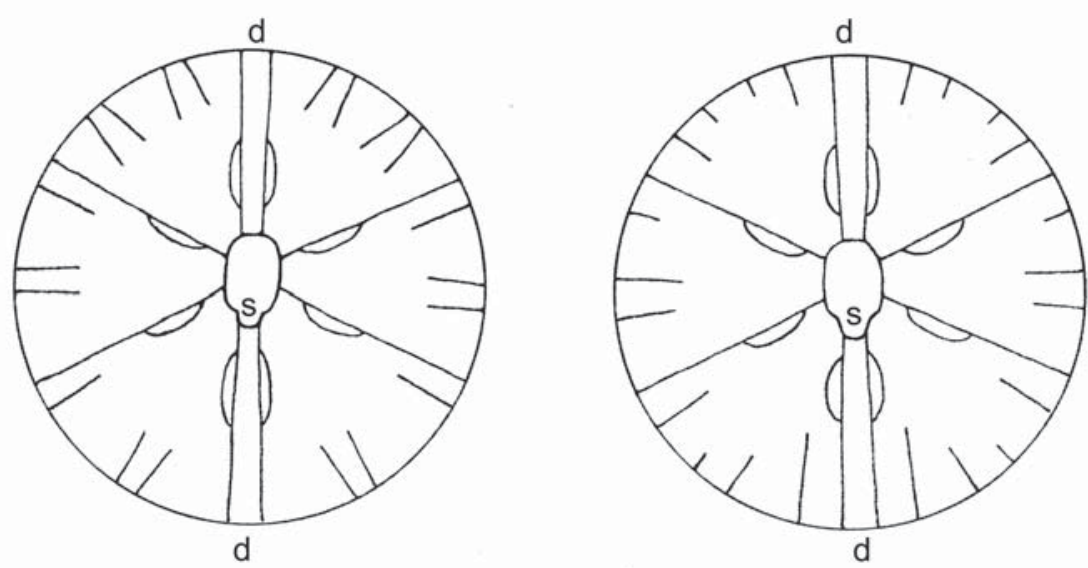

Fig. 4. Edwardsia inachi sp.n., arrangement of mesenteries in two specimens.

Abbreviations: d - directives; s - siphonoglyph.

Рис. 4. Edwardsia inachi sp.n., организация мезентериев в двух экземплярах.

Обозначения: d - направляющие пары мезентериев; s - сифоноглиф глотки.

Etymology. The species is named after the Chilean Antarctic Institute (Instituto Antárctico Chileno, INACH).

Remarks. Three genera of the family Edwardsiidae possess nemathybomes: Edwardsia de Quatrefages, 1842, Scolanthus Gosse, 1853 and Edwardsianthus England, 1987. Edwardsianthus currently contains only two species and characterized by the absence of the microcnemes in the first cycle of the mesenteries (England, 1987). The two remaining genera, $E d-$ wardsia and Scolanthus, are very similar to each other, Scolanthus differs from Edwardsia only by the absence of the physa. However, some Edwardsia species have very small physa making proper generic assignment difficult. The present species has non ampullaceous but rather clear physa and therefore is assigned to $E d$ wardsia rather than to Scolanthus.

The genus Edwardsia currently comprises about 50 valid species but only two species were known previously from the Antarctic: E. meridionalis Williams, 1981 and a species reported by Carlgren (1927) as E. intermedia McMurrich, 1893.

Edwardsia meridionalis differs clearly from $E$. inachi sp.n. by many features including the presence of only 16 tentacles, minute non protruding nemathybomes and very weak retractors (Williams, 1981).

The original description of Edwardsia intermedia is based on one poorly preserved spec- imen from Chile, the subsequent records include specimens from Subantarctic and Antarctic locations (Carlgren, 1899, 1927, 1959). According to the original description the periderm of this species is almost smooth, the species probably has no prominent mesogloeal tubercles which are characteristic for $E$. inachi sp.n., and "the tentacles are almost certainly not more than sixteen" (McMurrich, 1893: 137) and thus it cannot be conspecific with $E$. inachi sp.n. The identity of the specimens reported by Carlgren $(1899,1927,1959)$ is not quite clear and was discussed in details by Williams (1981). According to Williams (1981) some (but not all) of Carlgren's specimens, which have 16 tentacles, may be conspecific with his E. meridionalis. On the other hand some of the specimens reported by Carlgren (1927) have up to 28 tentacles that may suggest a possible relation with $E$. inachi sp.n.

High number of tentacles and numerous prominent mesogloeal papillae containing nemathybomes distinguish the present species from all other described Edwardsia species. Only four Edwardsia species have more than 20 tentacles:

Edwardsia neozelanica Farquhar, 1898 is a poorly known species which according to original description may have 16-24 tentacles but usually has 16 (Farquhar, 1898). According to Carlgren (1924) (who described it as E. tricolor Stuckey, 1908) it has two types of nematocysts 


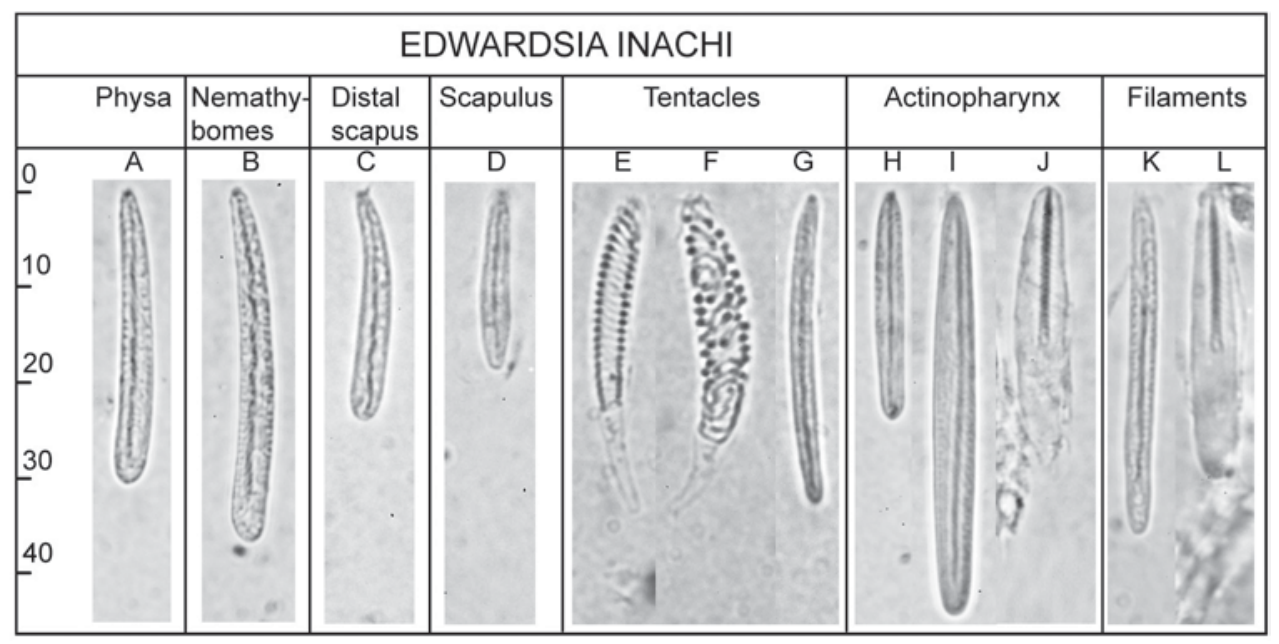

Fig. 5. Edwardsia inachi sp.n., cnidom (see Table 1 for size ranges).

Рис. 5. Edwardsia inachi sp.n., книдом (размеры указаны в табл. 1).

in the nemathybomes and thus differs from $E$. inachi sp.n.

Edwardsia finmarchica Carlgren, 1921 is a northern species known only from the original description from Norway (Carlgren, 1921). According to the original description some specimens may have up to 26 tentacles, but the nemathybomes in this species are very small and it is obviously different from E. inachi sp.n.

Edwardsia timida de Quatrefages, 1842 is another species known from the northern coasts of Europe which may have numerous (up to 36) tentacles. Unlike the present species nemathybomes in E. timida are small, not visible in live and contain two types of nematocysts (Manuel, 1988).

Edwardsia sipunculoides (Stimpson, 1853) originally described from the Atlantic coast of North America but also reported from the NE Pacific (see Torrey, 1902). According to Verrill (1922) the number of tentacles may vary from 24 to 36. Although it is not clear if all existing descriptions of E. sipunculoides belong to the same species, none of these descriptions mention mesogloeal papillae on the column, and according to Carlgren (1931) it has two types of nematocysts in the nemathybomes.

In addition at least some nemathybomes of Scolanthus ingolfi (Carlgren, 1921) are very prominent and located in mesogloeal papillae (see Carlgren, 1921, Fig. 68), but otherwise this species is not related to E. inachi sp.n. (in particular because it has only 16 tentacles).
Family Isanthidae Carlgren, 1938

\section{Armactinia gen.n.}

Column divisible into small base, scapus and scapulus. Scapus with tenaculi and cuticle. Single small mesogloeal sphincter situated close to base of tentacles. Tentacles more than 12 . Longitudinal muscles of tentacles and radial muscles of oral disc ectodermal. Six pairs of fertile macrocnemes with strong retractors and filaments, other mesenteries are microcnemes. Two pairs of directives attached to two siphonoglyphs. More mesenteries proximally than distally. Bilaterally symmetrical blunt headed spermatozoa. Cnidom: spirocysts, basitrichs, $\mathrm{p}$ mastigophores B1.

Type species: Armactinia antarctica sp.n.

Etymology. From Latin 'arma' armor.

\section{Armactinia antarctica sp.n.}

Table 2; Figs. 6-9, 31L.

Material examined. Holotype: ZIN 11333, ARD, 201002-13-(62), 35 m, (male, Fig. 6D). Paratype: KBPGI 432/ 1, RAS, 2011-02-21-(24), $32 \mathrm{~m}$, one specimen (female, Fig. 6C).

Additional material examined.

Cactosoma abyssorum: holotype, ZMBN 9797.

Eltaninactis infundibulum: AMNH-4261, Antarctica, West Deception Island, $61^{\circ} 58.50^{\prime} \mathrm{S}, 60^{\circ} 18.70^{\prime} \mathrm{W}, 804$ $930 \mathrm{~m}$, four specimens.

Eltaninactis psammophora: holotype, KBPGI 182/1, North Kurile Islands, 439-509 m. 
Halcampoides sp.: KBPGI 438/1, 439/2 and 440/3, East Kamchatka, 7.5-22 m, four specimens.

Isoparactis fabiani: KBPGI 294/1, Chile, Melinka, one specimen.

Isoparactis fionae: KBPGI 436/1, Chile, Punta Arenas, $4 \mathrm{~m}, 10$ specimens.

Neohalcampa sheikoi: KBPGI 181/5, North Kurile Islands, 430-504 m, two specimens.

Paraisanthus tamarae: holotype, KBPGI 134/1, Commander Islands, 0.5 m; KBPGI 146/13, Commander Islands, $16 \mathrm{~m}$, several specimens.

Peachia quinquecapitata: KBPGI 437/1, Sea of Okhotsk, $100 \mathrm{~m}$, one specimen.

Phellia crassa: syntypes, ZMBN 585, five specimens and ZMBN 2351, three specimens.

Urticina eques: KBPGI 406/3, Barents Sea, one specimen.

Description. External anatomy. The holotype (Fig. 6D) is $42 \mathrm{~mm}$ long and $27 \mathrm{~mm}$ in greatest diameter, and strongly contracted with oral and aboral parts deeply invaginated into the body. The paratype (Fig. $6 \mathrm{C}$ ) is $38 \mathrm{~mm}$ long, its diameter attains $20 \mathrm{~mm}$ in the middle of the body while the diameters of both oral and aboral extremities of the body are smaller, 16 and $11 \mathrm{~mm}$ respectively.

Base deeply invaginated in both specimens, especially in holotype (Fig. 6F), in which it forms a cavity resembling those seen in some other anemones living on soft bottom (e.g. some species of Actinauge), but here the cavity most probably is an artifact of contraction and not permanent. Sand grains and remnants of cuticle are attached to the lateral sides of this cavity, and few sand grains and patches of cuticle appear adherent on the roof of the cavity (i.e. to the central part of the base). In paratype the invaginated base is practically bare, with only a few sand grains attached and several loose patches of cuticle (Fig. 6E). The column is divided into scapus and scapulus. The scapus is covered by well developed thick ochre-coloured or yellowish cuticle. In paratype the cuticle forms thick overlapping scale-like concentrically wrinkled structures (Fig. 6C) to which gravel particles are firmly attached. The scapus of holotype is completely covered with gravel forming a solid and very firm crust (Fig. 6D). If the loose superficial layers cuticle are removed it becomes evident that sand grains are attached to tenaculi - short cylindrical elevations of mesogloea covered by a thick cuticular cap (Fig. $7 \mathrm{G})$. The scapulus is rather short and free from any attached foreign particles and cuticle. It has no scapular ridges, in preserved specimens transversely sulcated.
Both specimens have 24 tentacles which are hexamerously arranged in three cycles. They are rather short (in both living and preserved specimens) and pointed, with perforated tips (Fig. 7D), either uniformly coloured to the same orange-brownish colour as the oral disc, or are paler than the oral disc and have paler, almost whitish tips (Figs. 6A, B).

Internal anatomy and histology. The ectoderm of the scapus is about $150-300 \mu \mathrm{m}$, the endoderm 150-200 $\mu \mathrm{m}$ and the mesogloea 200 $500 \mu \mathrm{m}$ in the scapus and up to $800-900 \mu \mathrm{m}$ in the scapulus.

The compact mesogloeal marginal sphincter muscle is reticular, small and is located near the bases of the tentacles, its length in longitudinal sections through the distal part of the column is $900 \mu \mathrm{m}$, width is up to $280 \mu \mathrm{m}$ in distal part (Figs. 7D, E). Radial muscles of the oral disc and longitudinal muscles of the tentacles are ectodermal (Fig. 7F). Longitudinal muscles are better developed on the oral side of the tentacles.

The actinopharynx has numerous internal longitudinal folds and two shallow but discernible siphonoglyphs (Fig. 6G).

The mesenteries are arranged hexamerously in two cycles along the most length of the column (Fig. 6G, H): the six pairs of the first cycle are macrocnemes, of which two pairs are directives, and the six pairs of the second cycle are microcnemes. All microcnemes are imperfect, sterile and have no filaments and retractors (Fig. 7B). All macrocnemes, including directives, are perfect and fertile. Both oral and marginal stomata are present, their diameter varies from 0.3 to $2 \mathrm{~mm}$. Their retractors are very strong, circumscribed, pinnate, branched, with three to five large lobes on transverse sections on the level of actinopharynx (Figs. 6G, 7A). Very small mesenteries belonging to the third cycle are present only at the base, they are recognizable only in microscopic slides through this region (Fig. 7C). Well developed parietal muscles of macrocnemes form a very short fold on the side opposite to retractor. Muscles of the microcnemes are strong and resemble parietal part of macrocnemes (Fig. 7B). It is not quite clear if the specimens have true basilar muscles. The nature of the muscles running along the insertion of the mesenteries at the base is transitional. At the basal portion of 

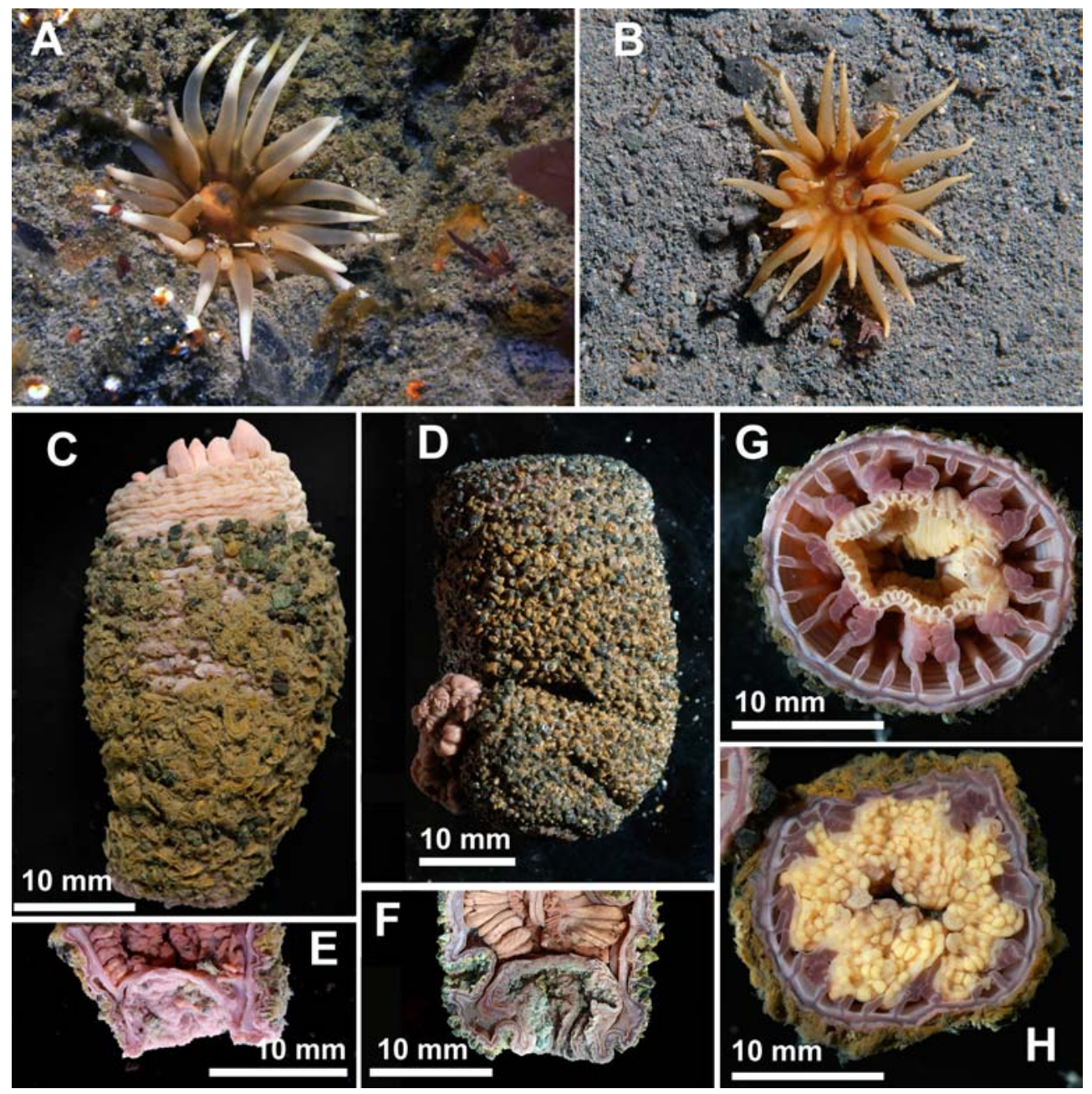

Fig. 6. Armactinia antarctica gen.n. sp.n., A-B - living specimens with expanded crown of tentacles; C$\mathrm{D}$ - the same specimens preserved in formalin; $\mathrm{E}-\mathrm{F}$ - longitudinal sections through aboral end of the body of both specimens; $\mathrm{G}-\mathrm{H}$ - transverse sections on the level of actinopharynx and below it. B, D and F holotype.

Рис. 6. Armactinia antarctica gen.n. sp.n., A-B - живые экземпляры с расправленными щупальцами; $\mathrm{C}-\mathrm{D}$ - те же экземпляры, фиксированные; E-F — продольные срезы через аборальный конец тела обоих экземпляров; $\mathrm{G}-\mathrm{H}$ - поперечный срез на уровне актинофаринкса и ниже него. $\mathrm{B}, \mathrm{D}$ и $\mathrm{F}-$ голотип.

the body the outer (running closer to the body wall) longitudinal muscle fibers of parietal muscles run along the insertion of the mesentery to the body wall, while the inner fibers run more obliquely and hit the base (and the outer muscle fibers) diagonally. The structure of these muscles is very similar to that described by Carlgren (1921: 125) for Cactosoma abyssorum. One cinclide was found in longitudinal sections of the most proximal part of scapus (Fig. 8A, B). Cinlides are not recognizable externally on preserved specimens, so their number and distribution cannot be identified. The acontia are absent. The sexes are separated. The diameter of the eggs is about $500 \mu \mathrm{m}$. The spermatozoa (Fig. 31L) resemble those of Actiniidae (Fig. $31 \mathrm{M}, \mathrm{N}$ ), they are bilaterally symmetrical with compact mitochondrial complex and have more 


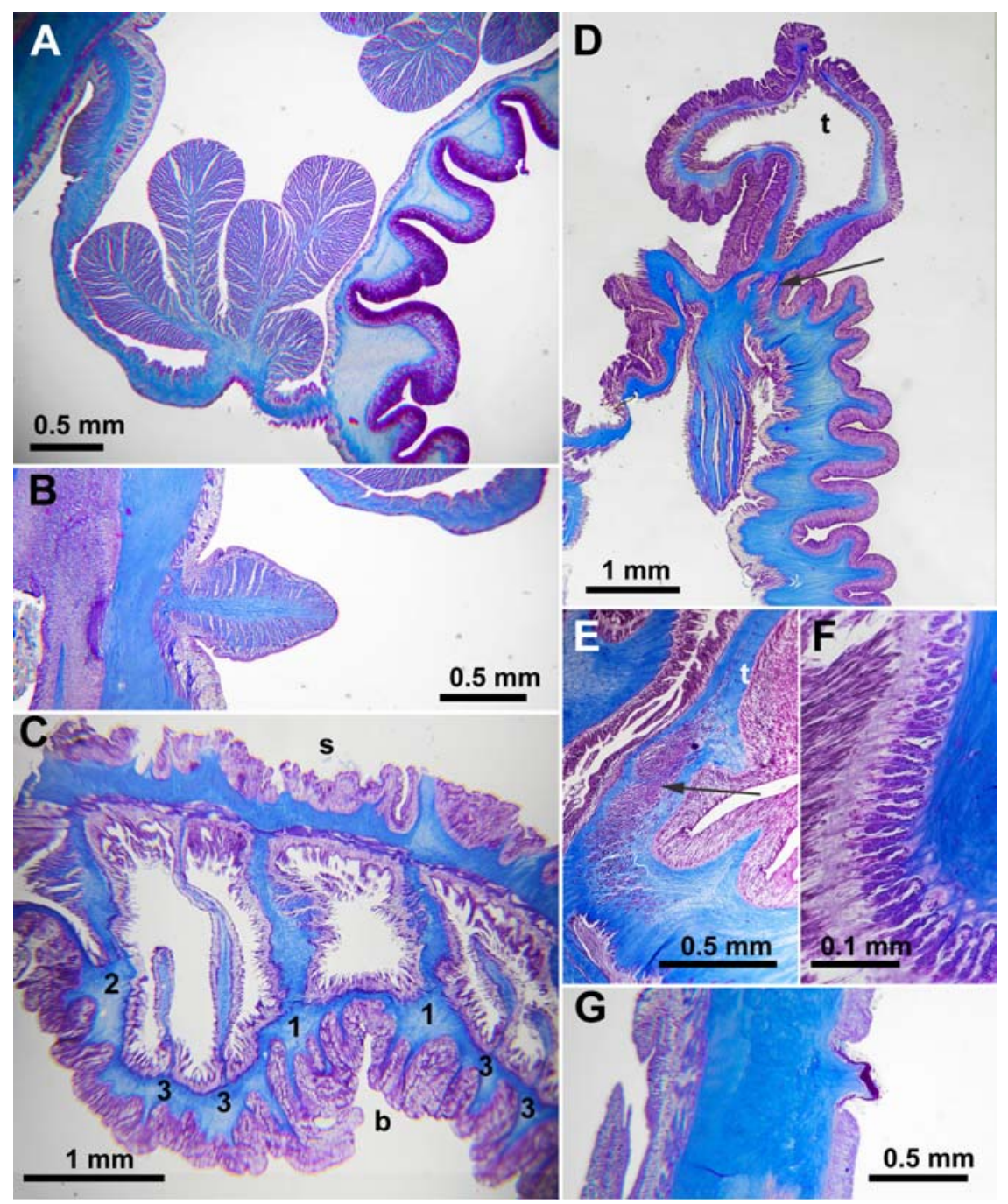

Fig. 7. Armactinia antarctica gen.n. sp.n., histological sections. A - transverse section showing a part of actinopharynx and a mesentery of the first order with large retractor; B - transverse section showing the mesentery of the second order; $\mathrm{C}$ - transverse section of the proximal part of the body through the wall of scapus and the base showing additional mesenteries of the third order; D - longitudinal section through the scapulus and tentacle, arrow indicates position of the sphincter; E - longitudinal section through distal end of the scapulus and base of the tentacle to show mesogloeal marginal sphincter (arrow), note how the sphincter extends to the base of the tentacle; F - ectodermal radial muscles of the oral disc; $\mathrm{G}$ - tenaculi. Abbreviations: $\mathrm{b}$ - base; $\mathrm{s}$ - scapus; $\mathrm{t}$ - tentacle; numbers $(1,2,3)$ indicate cycle of mesenteries.

Рис. 7. Armactinia antarctica gen.n. sp.n., гистологические срезы. А - поперечный срез, показывающий часть актинофаринкса и мезентерий первого цикла с большим ретрактором; В - поперечный срез через мезентерий второго цикла; $\mathrm{C}$ - поперечный срез проксимальной части тела через стенки скапуса и базы, показывающий дополнительные мезентерии третьего цикла; D - продольный срез через скапулюс и щупальце, стрелкой показано положение сфинктера; E - продольный срез через дистальный конец скапулюса и основание щупальца, виден маргинальный мезоглеальный сфинктер (стрелка), видно, что сфинктер проникает в основание щупальца; F — эктодермальные радиальные мускулы орального диска; $\mathrm{G}$ - тенакуля.

Обозначения: $\mathrm{b}$ - база; $\mathrm{s}$ — скапус; $\mathrm{t}$ — щупальце; цифрами $(1,2,3)$ обозначены номера циклов мезентериев. 
Table 2. Size ranges (length $\times$ width, in microns) and distribution of cnidae of Armactinia antarctica gen.n., sp.n. (measured in two specimens). Letters in brackets correspond to letters in Fig. 9.

Таблица 2. Размеры (длина $\times$ ширина, в микронах) и распределение стрекательных капсул Armactinia antarctica gen.n., sp.n. (по двум экземплярам). Буквы в скобках соответствуют буквам на рис. 9.

\begin{tabular}{|l|c|c|}
\hline Body region & Cnidae & Size ranges $(\mu \mathrm{m})$ \\
\hline \multirow{2}{*}{ Pedal disc } & (A) basitrichs (few) & $9-13 \times 1.5-2$ \\
& (B) basitrichs (common) & $16-22 \times 2-2.5$ \\
\hline \multirow{3}{*}{ Scapus } & (C) basitrichs (rare) & $8-11 \times 1.5$ \\
& (D) basitrichs (common) & $17-22 \times 2$ \\
\hline Scapulus & (E) p-mastigophores B1 (common) & $15-18 \times 3-4$ \\
\hline \multirow{2}{*}{ Tentacles } & (F) basitrichs (numerous) & $18-23 \times 2-2.5$ \\
\hline \multirow{2}{*}{ Actinopharynx } & (G) gracile spirocysts (numerous) & $23-45 \times 2-3$ \\
& (H) basitrichs (few) & $20-30 \times 2-2.5$ \\
\hline \multirow{2}{*}{ Filaments } & (I) basitrichs (common) & $24-29 \times 2-3$ \\
& (J) p-mastigophores B1 (numerous) & $25-32 \times 4-5$ \\
\hline
\end{tabular}

or less blunt (not pointed) head. The size of the head is about $3.5 \times 1.5 \mu \mathrm{m}$.

Cnidom. Gracile spirocysts, basitrichs, pmastigophores B1 (see Fig. 8E, 9 and Table 2 for size ranges and distribution).

Habitat. This species is burrowed in sand with only oral disc and the tentacles exposed on surface. The sediment layer, covering a solid rock at RAS, was coarse with pebbles in between. The divers did not observe that the collected specimen attached directly to the rock. Only two specimens were found during more than 50 dives.

Remarks. Comparison with similar species.

In the general shape of the body, the presence of cuticle, usually 24 tentacles, one cycle of macrocnemes, one or two cycles of microcnemes and in the absence of acontia Armactinia antarctica gen.n. sp.n. resembles the species assigned to genera Eltaninactis (Isanthidae) and Cactosoma (Halcampidae). Although currently assigned to different families these two genera are very similar. In Eltaninactis the basilar muscles are "weak in some individuals and imperceptible in others" (Dunn, 1983: 58) or "well-developed" (Rodríguez, López-González, 2013: 70) and in Cactosoma the exterior parts of the parietal muscles at the base were occasionally interpreted as basilar muscles and it was once suggested that it has true pedal disc (Carlgren, 1902; see also comments in Carlgren,
1921). As it seems, the nature of the base and the muscles running along the insertions of mesenteries do not constitute a difference between Eltaninactis and Cactosoma and the features of the body musculature and the base of both genera appear to be transitional. Dunn (1983: 58) come to the same conclusion regarding Eltaninactis: "in some respects this species appears transitional". When discussed its musculature she wrote that the muscles along both faces of each mesentery at its junction with the body wall appear in section to constitute parietal musculature, although its bundles are arranged diagonally (but not longitudinally as in typical parietal musculature), and, at the same time, they are not parietobasilar muscles. On her figure (Dunn, 1983, Fig. 67) the parietal muscle of $E$. infundibulum has a pronounced flap on the face of mesentery opposite to retractor, a feature not very common for typical parietal musculature. The type species of the genus Cactosoma, C. abyssorum Danielssen, 1890 has a very similar flap (see Carlgren, 1921, Fig. 151), again suggesting that these genera are related.

Due to similarity between Cactosoma and Eltaninactis we compare the present species with the members of both genera.

The genus Cactosoma currently comprises four species.

Cactosoma chilense (McMurrich, 1904) is known from one small and slender $(3 \mathrm{~mm}$ in 


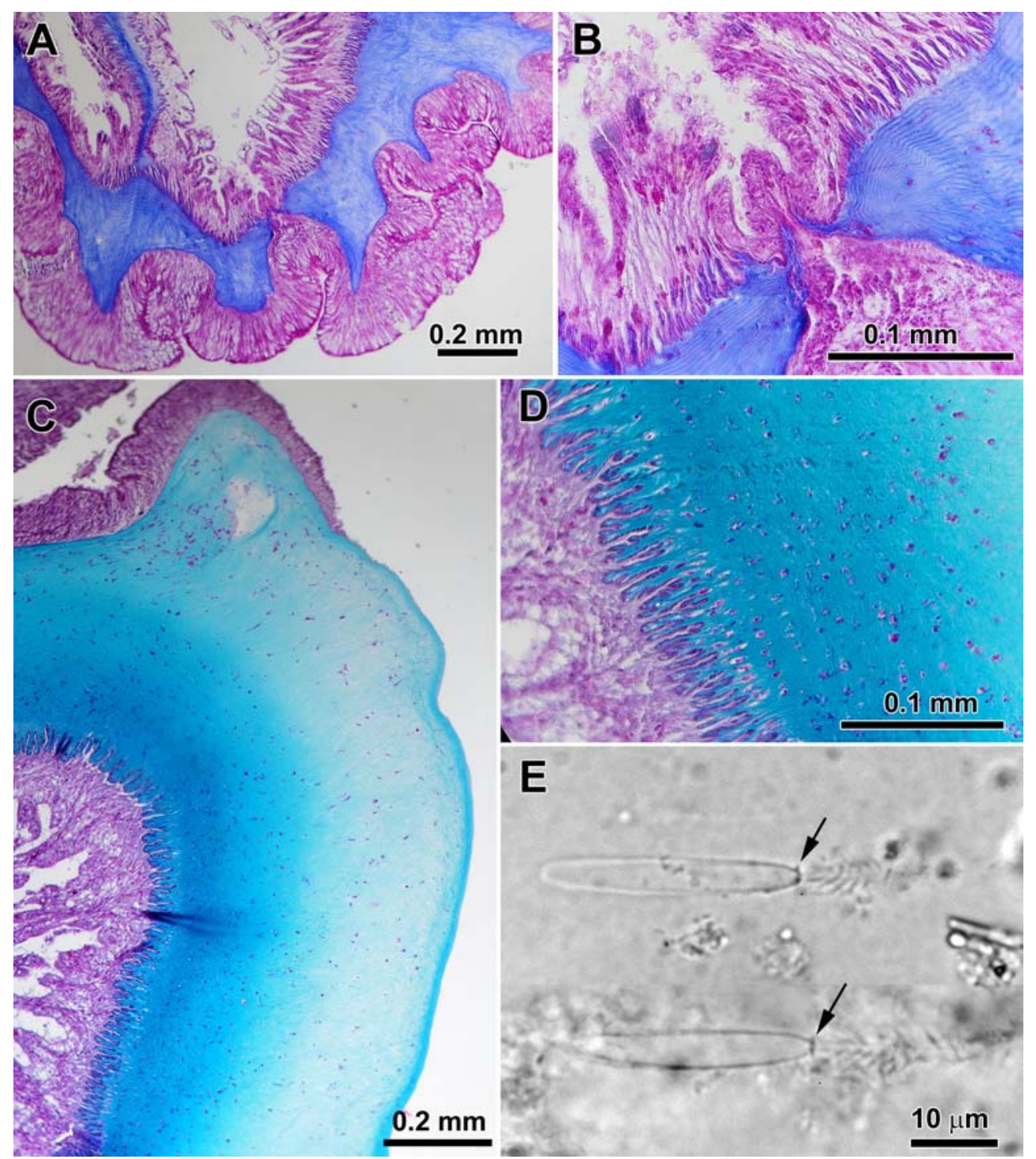

Fig. 8. Armactinia antarctica gen.n. sp.n. (A-B, E) and Eltaninactis infundibulum Dunn, 1983 (C-D). A longitudinal section through the limbus showing a cinclide; $\mathrm{B}$ - the same section, enlarged; C longitudinal section of the distal scapulus; D - detail of $\mathrm{C}$ at higher magnification showing sparse muscle fibres in mesogloea; E - fired p-mastigophores B1 from the actinopharynx, note the presence of the apical flaps (arrow).

Рис. 8. Armactinia antarctica gen.n. sp.n. (А-B, E) и Eltaninactis infundibulum Dunn, 1983 (C-D). A продольный срез через лимбус, видна цинклида; В — тот же срез, увеличено; C — продольный срез через дистальный скапулюс; D - увеличенный участок этого же региона, видны разбросанные одиночные мускульные фибриллы в мезоглее; Е - выстреленные р-мастигофоры В1 из актинофаринкса, стрелками указаны апикальные клапаны.

diameter), but adult (it had gonads on all macrocnemes) specimen from Chile. The shape of retractors differ distinctly from those of the present species (see McMurrich, 1904).
Cactosoma asperum (Stephenson, 1918) is known from single specimen from McMurdo Sound. The retractors and parietal muscles on transverse sections are similar to those of the 


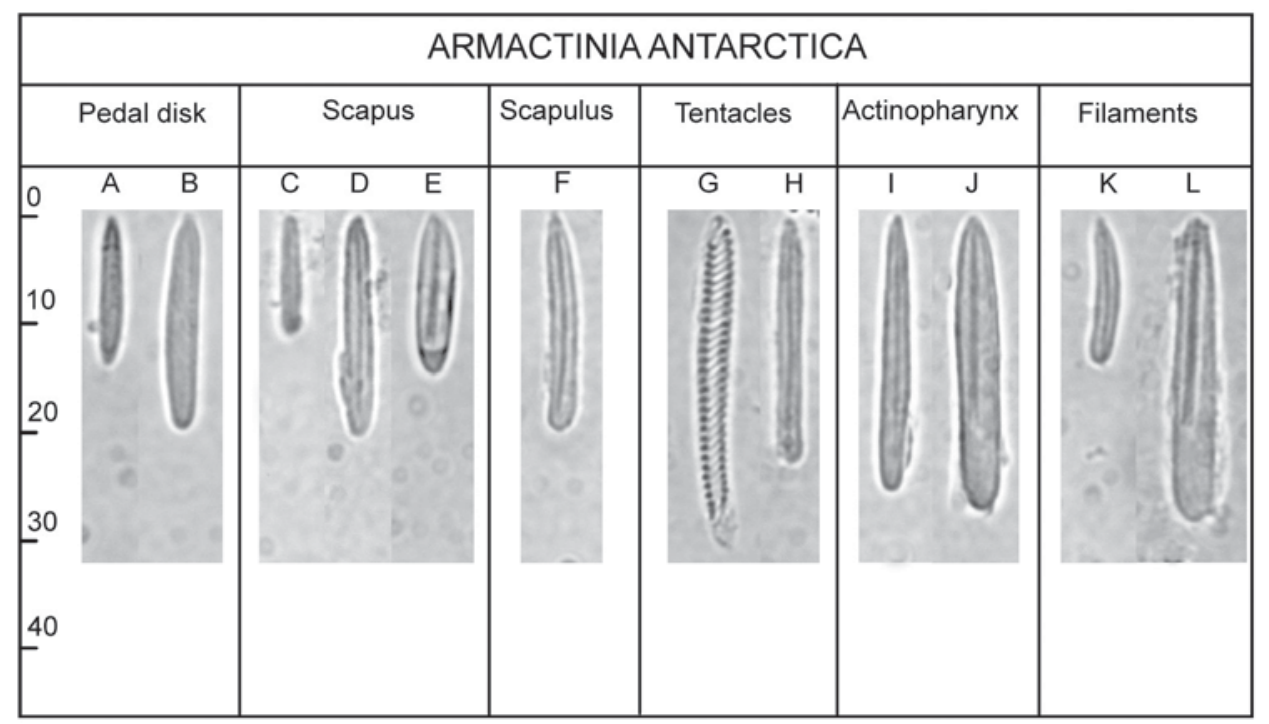

Fig. 9. Armactinia antarctica gen.n. sp.n., cnidom (see Table 2 for size ranges).

Рис. 9. Armactinia antarctica gen.n. sp.n., книдом (размеры указаны в табл. 2).

present species, in particular the parietal muscles, have a well developed flap (see Stephenson, 1918, Pl. 3, Fig. 2). Some points of the original description suggest that the species may be octomerous (eight ridges on "capitulum" (actually the scapulus) and 16 longitudinal ridges along the body), but this cannot be demonstrated clearly since Stephenson (1918) failed to access exact arrangement of the mesenteries. According to the original description it has up to 30 tentacles and 32 mesenteries, 13 of which are macrocnemes and thus cannot be conspecific with the present species (which has fewer tentacles).

The rest two species are geographically separated from the present species.

Cactosoma arenarium Carlgren, 1931 is a warm water species from California, it has an odd type of p-mastigophores in filaments.

Cactosoma abyssorum, the type species of the genus, is based on one specimen described from Norwegian Sea. Carlgren's (1921) subsequent description of $C$. abyssorum is based partly on Danielssen's (1890) specimen (the holotype) and partly on specimens of Phellia crassa Danielssen, 1890, which he considered conspecific with C. abyssorum.

The genus Eltaninactis currently comprises two species.

Eltaninactis infundibulum Dunn, 1983, the type species of the genus is known from Antarc- tic and has many features similar with those of the present species. Both species share the number of the tentacles (24), one cycle of macrocnemes with strong retractors and well developed parietal muscles and two cycles of microcnemes (the youngest of which is present only proximally), as well as a strong cuticle on the scapus. Despite significant similarity the present species cannot be conspecific with E. infundibulum which has a wide base, rather different from the small base of the present species, and, according to our data, has no sphincter muscle. According to Dunn (1983: 57) in E. infundibulum the sphincter consists of a "few muscle bundles scattered between upper scapus and base of tentacles hugging endodermal side of mesogloea; width at most a quarter that of scapulus wall". On the photograph reproduced by Dunn (1983, Fig. 68) the sphincter muscle is difficult to recognize. Rodríguez, López-González (2013) also reported that the sphincter is mesogloeal and very weak. We examined several specimens of this species (courtesy of Dr. E. Rodríguez). The mesogloea of the column of the most closely examined specimen (AMNH-4261) contains fine, sparse, widely separated from each other muscle fibres which are somewhat more numerous at endodermal side of the mesogloea in the region of scapulus, but it is hard to say that they form a marginal sphincter mus- 
cle (Fig. 8C, D). In contrast, in the present species the compact sphincter occupies almost the whole width of the mesogloea and muscle bundles are crowded and not as spaced as in $E$. infundibulum. We failed to find oral or marginal stomata in E. infundibulum which are present in $A$. antarctica sp.n. In addition, we found spirocysts (common) in the scapulus of E. infundibulum which are absent in this region in the present species. The length of the shaft in unfired pmastigophores in E. infundibulum is about half of the length of the capsule, while in the present species it is longer, three quarters or longer. The scarce p-mastigophores with longer shaft reported for E. infundibulum by Rodríguez, López-González (2013, Fig. 38 J and N) are immature capsules of the nematocysts showed by these authors on Fig. 38 I and L respectively. Pmastigophores with shorter and longer shaft reported by Rodríguez, López-González (2013) in the actinopharynx (Fig. $38 \mathrm{I}$ and J) and filaments (Fig. $38 \mathrm{~L}$ and N) have the same number of turns of spine-rows on the shaft. The sizes of immature capsules are usually slightly larger that those of matured capsules (our data). The shaft in unfired capsules shortens during maturation of cnidae, this fact is established in literature for $\mathrm{p}$-mastogophores (in particular for Metriduim, see Östman et al., 2010).

Eltaninactis psammophora Sanamyan, 2001 from NW Pacific is similar to A. antarctica sp.n. in many features including the general spindleshaped body form (in preservative), the shape of the sphincter, but the retractors are different, it has fewer tentacles and six very prominent scapular ridges (see Sanamyan, 2001, Fig. 6). Sanamyan (2001) recognized a relationship of her species with Cactosoma, but it was assigned to Eltaninactis due to the presence of basilar muscles and on the fact that the species has a scapulus, while Carlgren (eg. Carlgren, 1921, 1949) refers to the upper region of the body in Cactosoma as a capitulum. Carlgren in his earlier works (e.g. Carlgren, 1921) used the term capitulum instead of the scapulus for many species (e.g. for Edwardsia), and Cactosoma has a scapulus, but not a capitulum (as is evident from the original description, see Danielsen's, 1890, Tabl. VI, Fig. 5, and our type revision). The assignment of this species in Eltaninactis is dubious, the nature of the sphincter muscle suggests closer similarity with Cactosoma than to Eltaninactis.

Generic and familiar assignment.

Armactinia gen.n. differs from Eltaninactis by the presence of compact mesogloeal sphincter muscle located at the bases of the tentacles, which resembles the sphincter of Cactosoma, (see Carlgren, 1921), while in type species of Eltaninactis several spaced muscle fibers do not form a definite sphincter, and Armactinia gen.n. differs from both genera in the shape of spermatozoa.

The fact that the shape of spermatozoa may be a feature of high importance for delimiting large groups of anemones was established in the works of Schmidt (e.g. Schmidt, 1972a; 1974). This feature, although was not widely used by other authors, seem to be reliable: during the present study we examined several species and confirmed that the related taxa have similar shape of spermatozoa and the shape of the spermatozoa is probably more or less the same in the related genera (see Fig. 31).

The shape of the head of the spermatozoa in E. infundibulum (specimen AMNH-4261) is typical for many mesomyarian anemones (radially symmetrical, tip headed, Fig. 31 B-H), while in the present species spermatozoa resemble those of endomyarian anemones (Fig. $31 \mathrm{M}-$ N). (Schmidt, 1972a and 1974 used the term "round headed" which is not quite correct, the head is rather "bilaterally symmetrical" than round, the round headed spermatozoa have, for example, Peachia, Corallimorphus and Dactylanthus, see Fig. $31 \mathrm{O}-\mathrm{Q})$.

The holotype of C. abyssorum (ZMBN 9797) currently consists of a small portion of distal end of the body. We failed to study spermatozoa and nematocysts of this specimen, the tissues are firm and opaque and we found only spirocysts $(24-46 \times 3-4 \mu \mathrm{m})$ and several basitrichs (15-19 $\times 2-3 \mu \mathrm{m})$. However, we were able to study the shape of spermatozoa in the type material of $P$. crassa (ZMBN 585 and 2351, labeled as syntypes by D.G. Fautin), a species synonymized by Carlgren (1921) with C. abyssorum. We examined in details two dissected specimens, one with attached sand grains and spindle shaped body, another low, with wide base and without sand on column (they probably belong to two different species). One of these specimens (the one with sand on column) was figured and identified by Carlgren (1902) as Phelliomorpha 
crassa (Danielssen, 1890). The specimen examined by Carlgren (1902) was a male and had radially symmetrical tip headed spermatozoa resembling spermatozoa of Eltaninactis but not bilaterally symmetrical blunt headed spermatozoa of the present species.

Thus the present species does not appear to be closely related to Eltaninactis and Cactoso$m a$ and cannot be assigned to these genera and we establish a new genus Armactinia gen.n. for it.

On the other hand the genera Cactosoma and Eltaninactis are similar in almost all important morphological features (including the shape of spermatozoa) and their placement in separate families is problematic. However, in the present work we refrain to change familiar placement of Eltaninactis pending detailed study of the species currently assigned to Halcampidae.

The cnidom of Armactinia gen.n. with only p-mastigophores B (thick walled and with apical flaps, Fig. 8E) and without p-mastigophores A and its bilaterally symmetrical spermatozoa render its position closer to members of Isanthidae rather than to Halcampidae. Several species of Isanthidae we examined (Isoparactis fabiani (Häussermann, Försterra, 2008), I. fionae Lauretta et al., 2013 and Paraisanthus tamarae Sanamyan et Sanamyan, 1998) have pmastigophores B and bilaterally symmetrical spermatozoa with very compact mitochondrial complex (about $1 \mu \mathrm{m}$ diameter) although the tip of the head is more pointed than in Armactinia gen.n. (see Fig. $31 \mathrm{I}-\mathrm{L}$ ). Spermatozoa of these species are very different from those of other anemones with mesogloeal sphincter for which this character is known (including Actinostolidae and Sagartiidae, see Fig. 31B, C). In the present work we place Armactinia gen.n. within Isanthidae, a family currently comprising several genera with mesogloeal sphincter, mesenteries divisible on macro- and microcnemes, and originally described as having no acontia, although they were subsequently found in some species (see Lauretta et al., 2013).

Family Hormathiidae Carlgren, 1932

Hormathia lacunifera (Stephenson, 1918) Table 3; Figs. 10-11, 31H.

Lilliella lacunifera Stephenson, 1918: 33.

Hormathia lacunifera: Carlgren, Stephenson, 1929: 24. Dunn, 1983: 50 (and synonymy). Rodríguez, LópezGonzález, 2013: 77 (and synonymy).
Material examined. PNS, 2010-02-16, $30 \mathrm{~m}$, one specimen (female); 2011-02-12-(07), $40 \mathrm{~m}$, one specimen (female); 2011-02-12-(21), $40 \mathrm{~m}$, one specimen (sterile). RAS, 2010-02-18, $32 \mathrm{~m}$, two specimens (male and female).

Description. External and internal anatomy and histology. The smallest (sterile) specimen is $10 \mathrm{~mm}$ in height and $14 \mathrm{~mm}$ diameter, other specimens are fertile and are $31-45 \mathrm{~mm}$ high and 33-41 $\mathrm{mm}$ diameter. The scapus of living specimens is covered by thin dark brown cuticle. The scapulus is very short, involuted on preserved specimens (Fig. 10C). Ectoderm of scapus, scapulus and oral disc is bright yelloworange, the tentacles are pale (Figs. 10A, B). The marginal mesogloeal sphincter is large, alveolar, 1/4 of its length is in the scapulus and $3 / 4$ in the scapus. On longitudinal sections through the distal part of column it appears longitudinally or transversely stratified. The sphincter is widest distally (in the scapulus and distal part of the scapus) and narrows in proximal direction. It is clearly separated from the endodermal columnar muscles by a layer of mesogloea. In largest specimen $(45 \mathrm{~mm})$ the length of the sphincter is $16 \mathrm{~mm}$, width up to 1.8 $\mathrm{mm}$ (Fig. 10E). In all specimens mesenteries are arranged hexamerously in four cycles $(6+6+$ $12+24$ pairs, but $6+6+12+26$ in one specimen). Mesenteries of the first cycle are perfect and sterile, all other mesenteries fertile (Fig. 10D). Oral and marginal stomata not present. On the mesenteries of the second cycle gonads are developed only distally in a narrow zone where trilobate filaments are located, while on the mesenteries of the third and the fourth cycles the gonads present along most length of column.

Cnidom. Gracile and robust spirocysts, basitrichs, p-mastigophores A, p-mastigophores B1 (see Fig. 11 and Table 3 for size ranges and distribution).

The smallest sterile specimen has unusual thick holotrichs in cnidoglandular tracts of unilobate and trilobate filaments which also occasionally occurred in the endoderm of mesenteries, column and tentacles and in the ectoderm of scapulus and tentacles (their presence in these tissues was confirmed on histological sections) (Fig. $11 \mathrm{O}$ ). These holotrichs were not present in other examined specimens and are not known for other Hormathia species. This specimen has an additional type of basitrichs (Fig. 11L) not 

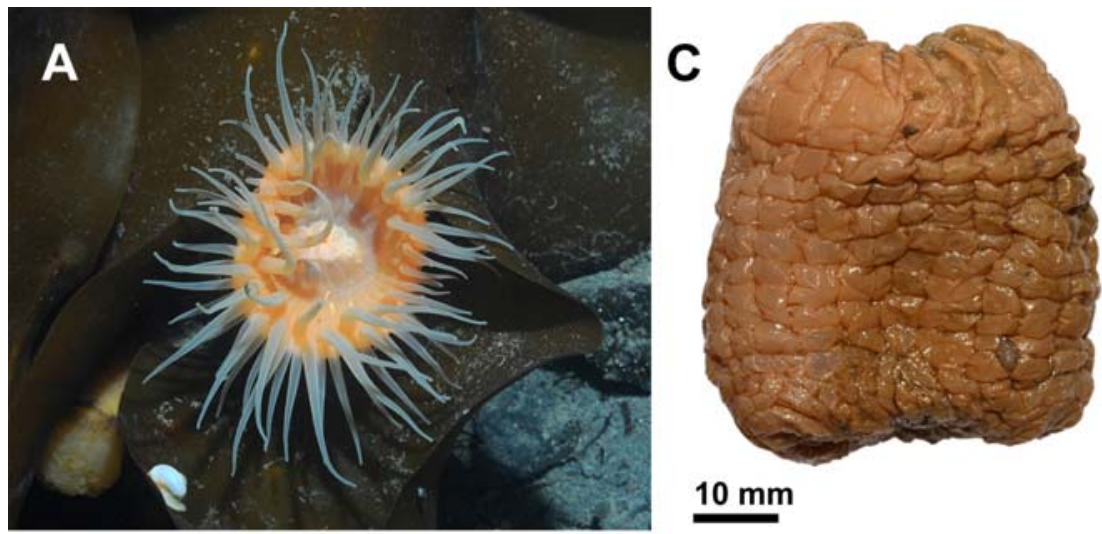

\section{$10 \mathrm{~mm}$}
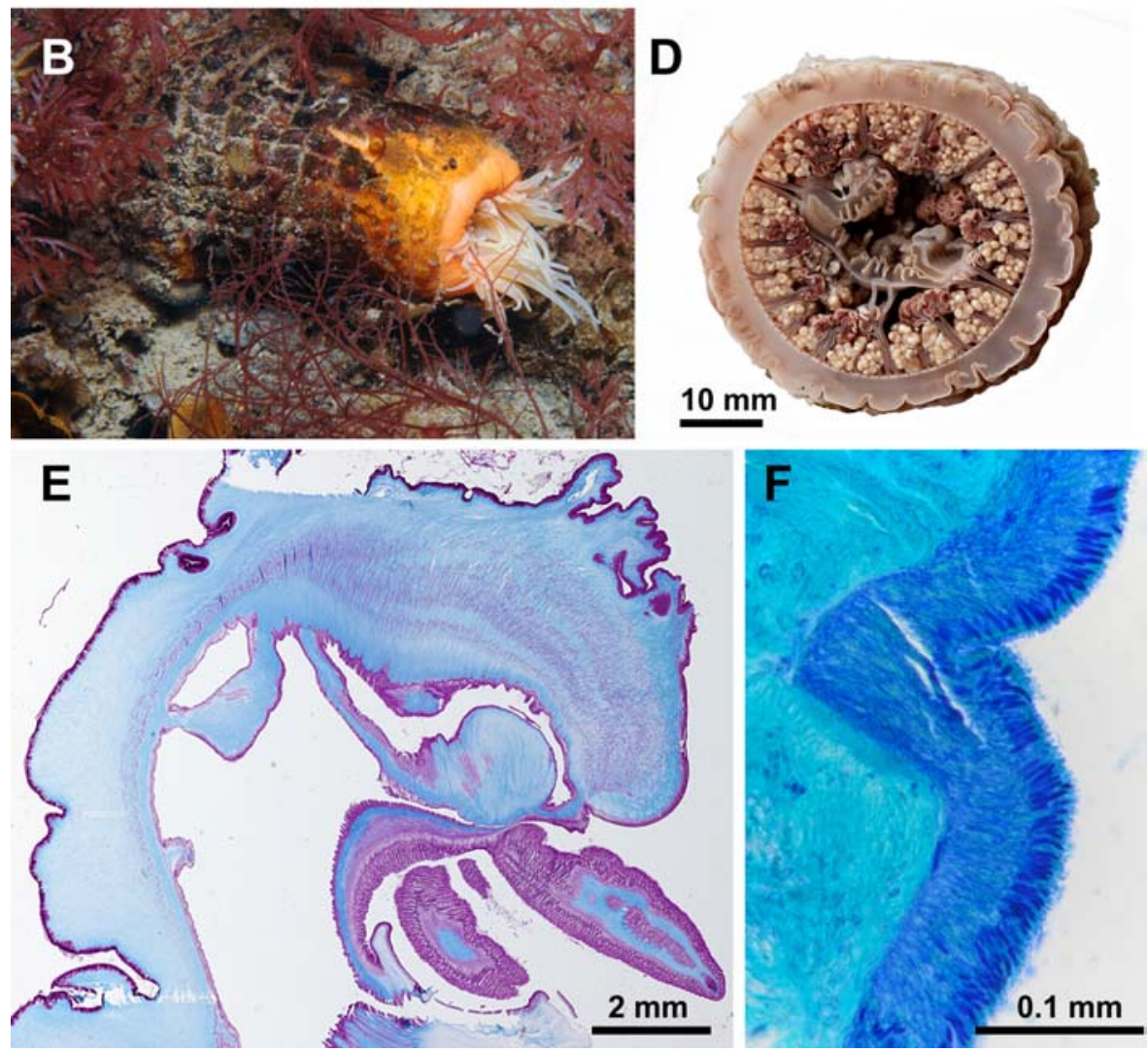

Fig. 10. Hormathia lacunifera (Stephenson, 1918). A — living specimen from RAS from the top; B - living specimen from PNS, side view, note dark cuticle and short bare scapulus; $\mathrm{C}$ - the specimen from PNS preserved in formalin; D - the same specimen sectioned transversely, note regular hexamerous organization of four cycles of mesenteries; E - longitudinal section though distal column to show appearance of mesogloeal sphincter; F - crowded basitrichs in the ectoderm of the scapulus.

Рис. 10. Hormathia lacunifera (Stephenson, 1918). А - живой экземпляр из RAS, вид сверху; В живой экземпляр из PNS, вид сбоку, видна темная кутикула и голый скапулюс; C - экземпляр из PNS, фиксированный; D - тот же экземпляр, поперечный срез, видна правильная гексамерная организация мезентериев; E - продольный срез через дистальную часть колюмна, показывающий внешний вид сфинктера; F — густо расположенные базитрихи в эктодерме скапулюса. 
Table 3. Size ranges (length $\times$ width, in microns) and distribution of cnidae of Hormathia lacunifera. Letters in brackets correspond to letters in Fig. 11. "N" - ratio of number of specimens in which each cnidae was found to number of specimens examined.

Таблица 3. Размеры (длина $\times$ ширина, в микронах) и распределение стрекательных капсул Hormathia lacunifera. Буквы в скобках соответствуют буквам на рис. 11. "N" - отношение экземпляров, в которых данный тип книд был найден, к количеству исследованных экземпляров.

\begin{tabular}{|l|c|c|c|}
\hline Body region & Cnidae & Size ranges $(\mu \mathrm{m})$ & $\mathrm{N}$ \\
\hline Pedal disc & (A) basitrichs (few) & $17-26 \times 2.5-3$ & $5 / 5$ \\
\hline Scapus & (B) basitrichs (few) & $15-25 \times 2.5-3.5$ & $4 / 4$ \\
\hline Scapulus & (C) basitrichs (numerous) & $17-30 \times 2-3.5$ & $5 / 5$ \\
\hline \multirow{4}{*}{ Tentacles } & (D) gracile spirocysts (numerous) & $25-41 \times 2-4$ & $3 / 3$ \\
& (E) robust spirocysts (numerous) & $19-50 \times 3.5-6$ & $3 / 3$ \\
& (F) basitrichs (numerous) & $20-30 \times 2-3$ & $3 / 3$ \\
\hline \multirow{4}{*}{ Actinopharynx } & (G) basitrichs (rare) & $15-23 \times 1.5-2.5$ & $5 / 5$ \\
& (H) basitrichs (common) & $25-44 \times 3-4$ & $5 / 5$ \\
& (I) p-mastigophores A (common) & $23-38 \times 4-7$ & $5 / 5$ \\
Filaments & (J) p-mastigophores B1 (rare) & $20-29 \times 3.5-4.5$ & $5 / 5$ \\
& (K) basitrichs (few) & $13-20 \times 1.5-2.5$ & $5 / 5$ \\
& (L) basitrichs (rare) & $25-29 \times 2.5-3$ & $1 / 5$ \\
& (M) basitrichs (common) & $35-50 \times 4-5$ & $5 / 5$ \\
\hline \multirow{2}{*}{ Acontia } & (N) p-mastigophores B1 (common) & $18-27 \times 3.5-5$ & $5 / 5$ \\
& (O) holotrichs (common) & $38-47 \times 12-16$ & $1 / 5$ \\
\hline
\end{tabular}

present in other examined specimens. Otherwise the cnidom of this small specimen agreed with the cnidom of other four specimens.

Most p-mastigophores in the actinopharynx are thin walled p-mastigophores A. Thick walled p-mastigophores B1 are very rare in the actinopharynx but common in the filaments.

Only one sort of basitrichs (Fig. 11F) is present in the ectoderm of the tentacles. Rare basitrichs of smaller size $(13-15 \times 1.5-2 \mu \mathrm{m})$ are present in the endoderm of the tentacles. Occasional spirocysts occur in the ectoderm of the actinopharynx and cnidoglandular tracts of the filaments (confirmed on histological sections). Basitrichs on the limbus are of the same sort as in pedal disc and scapus but they are more numerous here. Basitrichs in the scapulus form a dense layer of crowded capsules (Fig. 10F). Small basitrichs in filaments (Fig. 11K) are rare in the cnidoclandular tracts but common in the digestive region near cnidoglandular tracts. They also sporadically occur in the endoderm of other parts of the body. Only one sort of p-mastigo- phores is present in the filaments. Rodríguez, López-González (2013, Fig.45 O, P, Table 17) reported two sorts of p-mastigophores in filaments, but these capsules belong to one sort, one capsule (Fig. 45P) is an immature stage of the second (Fig. $45 \mathrm{O}$ ).

Spermatozoa very small $(2-2.5 \times 1.5 \mu \mathrm{m})$, radially symmetrical, with blunt head and wide mitochondrial complex (Fig. 31H).

Remarks. We found numerous thin walled p-mastigophores A in actinopharynx of this species. These nematocysts were already reported for Hormathiidae by Hartog (1977) who reported them in the actinopharynx of Hormathia coronata (Gosse, 1858) and Cataphellia brodricii (Gosse, 1859).

The specimens from the present material correspond well with the description provided by Dunn (1983) (although we failed to find spirocysts in the scapus) so we identify them as Hormathia lacunifera. Dunn (1983) examined more than 150 specimens identified as $\mathrm{H}$. lacunifera, she synonymized several other Southern 


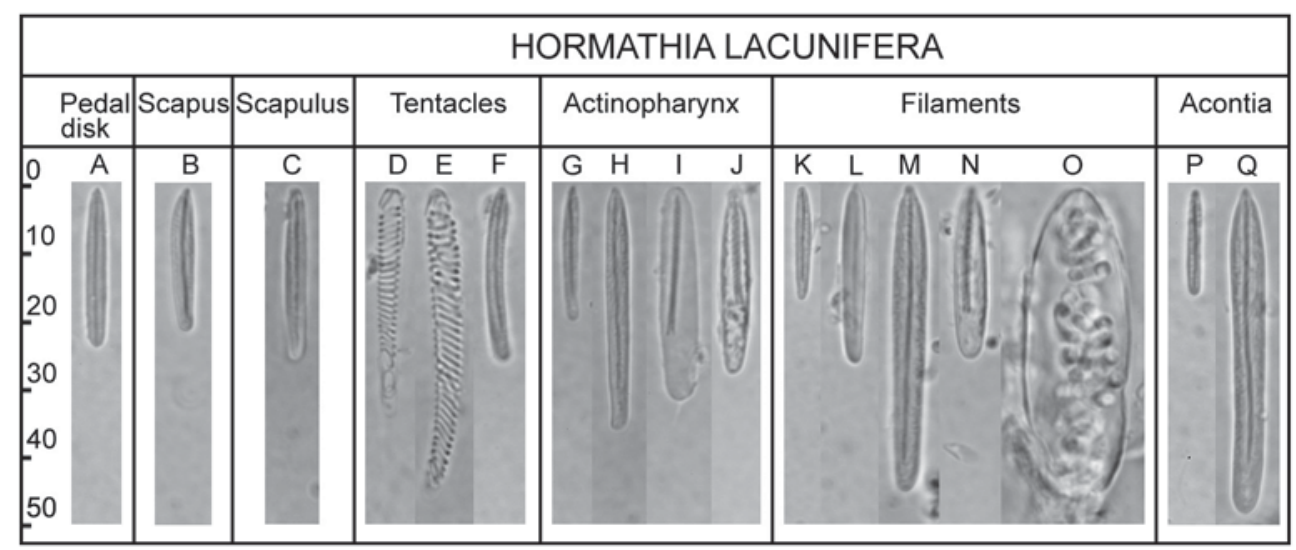

Fig. 11. Hormathia lacunifera (Stephenson, 1918), cnidom (see Table 3 for size ranges).

Рис. 11. Hormathia lacunifera (Stephenson, 1918), книдом (размеры указаны в табл. 3).

Ocean Hormathia species with it and considered this species circumpolar. It should be noted, however, that the taxonomic status of this species is problematic. Its original description is based on a single specimen collected off Barne Glacier, McMurdo Sound, at about 370 m. According to Stephenson (1918) it was so poorly preserved that "all but the body-wall and the frames of the mesenteries [...] are absolutely decomposed into a homogeneous mass". The column of the type specimen was smooth, without cuticle and ectoderm and Stephenson (1918) found many lacunae in the body wall, he was sure these lacunae are not artifacts because they had epithelial lining. He failed to detect acontia and established a genus Lilliella for it. Despite the lack of clarity regarding the taxonomic position of Stephenson's specimen Carlgren and Stephenson (1929) identified several specimens from the Indian sector of the Antarctic (i.e. collected far from the type locality of L. lacunifera) as this species. They regarded lacunae as possible artifacts (leaving aside and not discussing the nature of epithelial lining seen by Stephenson, 1918) and found numerous acontia and thus assigned this species to the genus Hormathia. In our opinion the condition of the type specimen of $L$. lacunifera, as described by Stephenson (1918), does not allow to identify its correct taxonomic position.

Hormathia georgiana Carlgren, 1927 originally described from South Georgia is a very similar species, although the colour of the living specimens (dark-brown tentacles and white oral disc), as described by Carlgren (1927), differs from the present specimens identified as $H$. lacunifera. Dunn (1983) says H. georgiana differs from $H$. lacunifera by its nematocysts, however the nematocyst data provided by Carlgren (1927) for H. georgiana do not differ from those reported by Carlgren, Stephenson (1929) and Dunn (1983) for H. lacunifera. On the other hand the nematocyst data for a syntype of $H$. georgiana (SMNH-type-4012) provided by Rodríguez, López-González (2013: 81) show some differences in types and size ranges of nematocyst from $H$. lacunifera. Referring to high variability of this species Rodríguez, López-González (2013) synomymized H. georgiana with $H$. lacunifera.

Family Sagartiidae Gosse, 1858

Artemidactis victrix Stephenson, 1918

Table 4; Figs. 12-14, 31C.

Artemidactis victrix Stephenson, 1918: 41. Carlgren, 1927: 84. Carlgren, Stephenson, 1929: 24.

Artemidactis vixtrix: Carlgren, 1939: 797.

Material examined. PNS, 2011-02-07-(10), $5 \mathrm{~m}$, two specimens (Fig. 12C). ESC, 2011-02-01-(12), 9 m, two small specimens; 2011-01-31-(18), 8m, one small specimen. RAS, 2010-02-11, one specimen.

Additional specimens examined: Chile, Magallanes Region, Punta Arenas, 2008-06-17, one specimen.

Description. The collected specimens are small, the largest is $17 \mathrm{~mm}$ high and $29 \mathrm{~mm}$ diameter. The size of living specimens is up to about $15 \mathrm{~cm}$ in height or smaller (Fig. 12C, D). The column of well expanded living specimens 


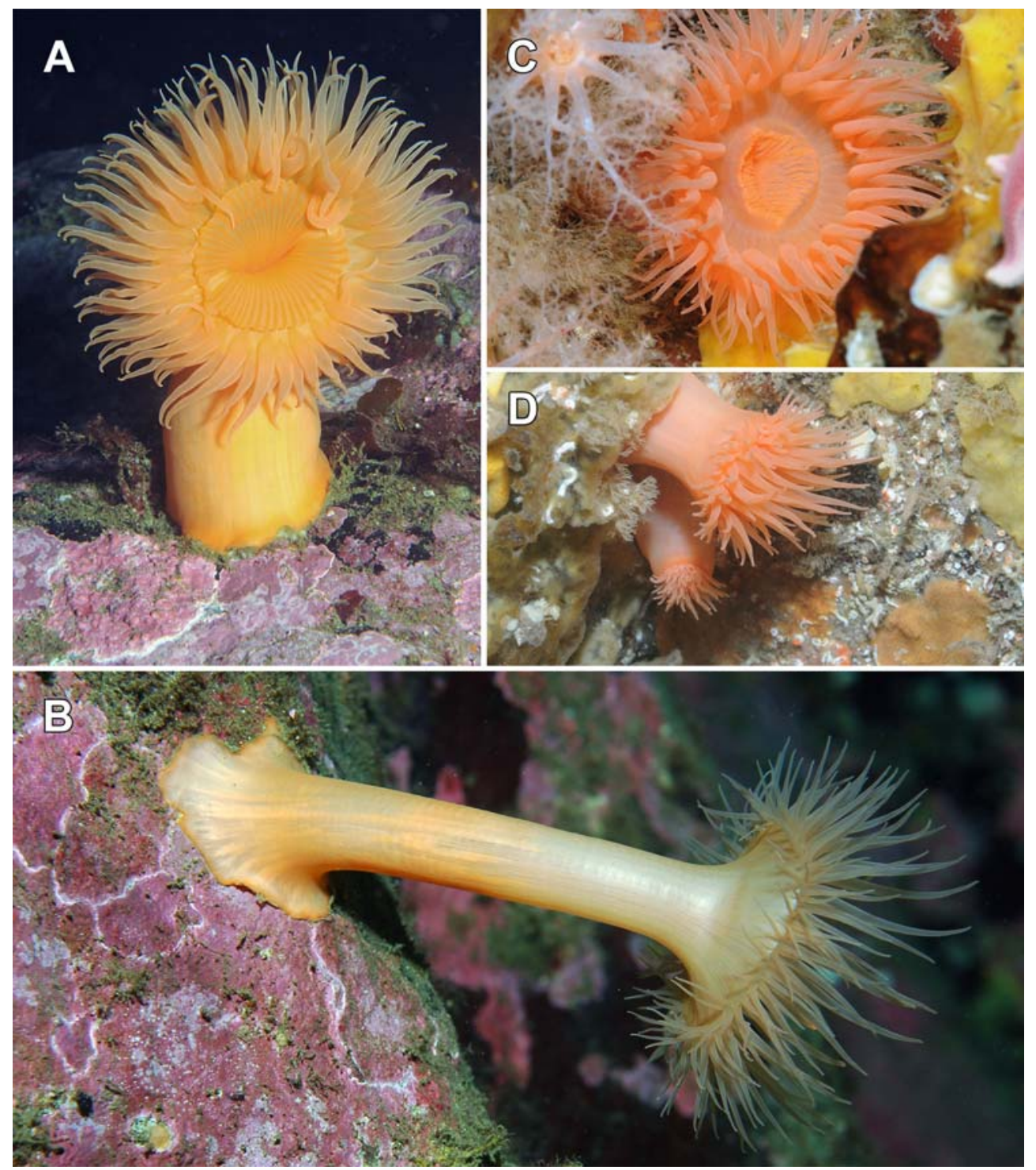

Fig. 12. Artemidactis victrix Stephenson, 1918. A-B — specimens from South Chile (Region de Magellanes); $\mathrm{C}-\mathrm{D}$ - specimens from King George Island (PNS).

Рис. 12. Artemidactis victrix Stephenson, 1918. А-В - экземпляры из района южного Чили (Магеллановы острова); C-D — экземпляры из района острова Короля Георга (PNS).

is cylindrical along the most of its length and wider proximally and distally (Fig. 12B).

The marginal mesogloeal sphincter on longitudinal sections is $3 \mathrm{~mm}$ long and up to $1.2 \mathrm{~mm}$ width. It occupies almost the whole width of the mesogloea in its distal part and narrows proximally, and is clearly separated from the circular endodermal muscles by thin layer of the mesogloea (Fig. 13A). The most distal part of the sphincter (near the tentacles) is reticular, but in whole its structure cannot be described as reticular or alveolar. The muscle meshes in the mesogloea are elongated and arranged into groups (Fig. 13B). The longitudinal muscles of the tentacles are ectodermal.

Mesenteries in our specimens are arranged hexamerously. The number of mesenteries in the middle part of the column is about two times 


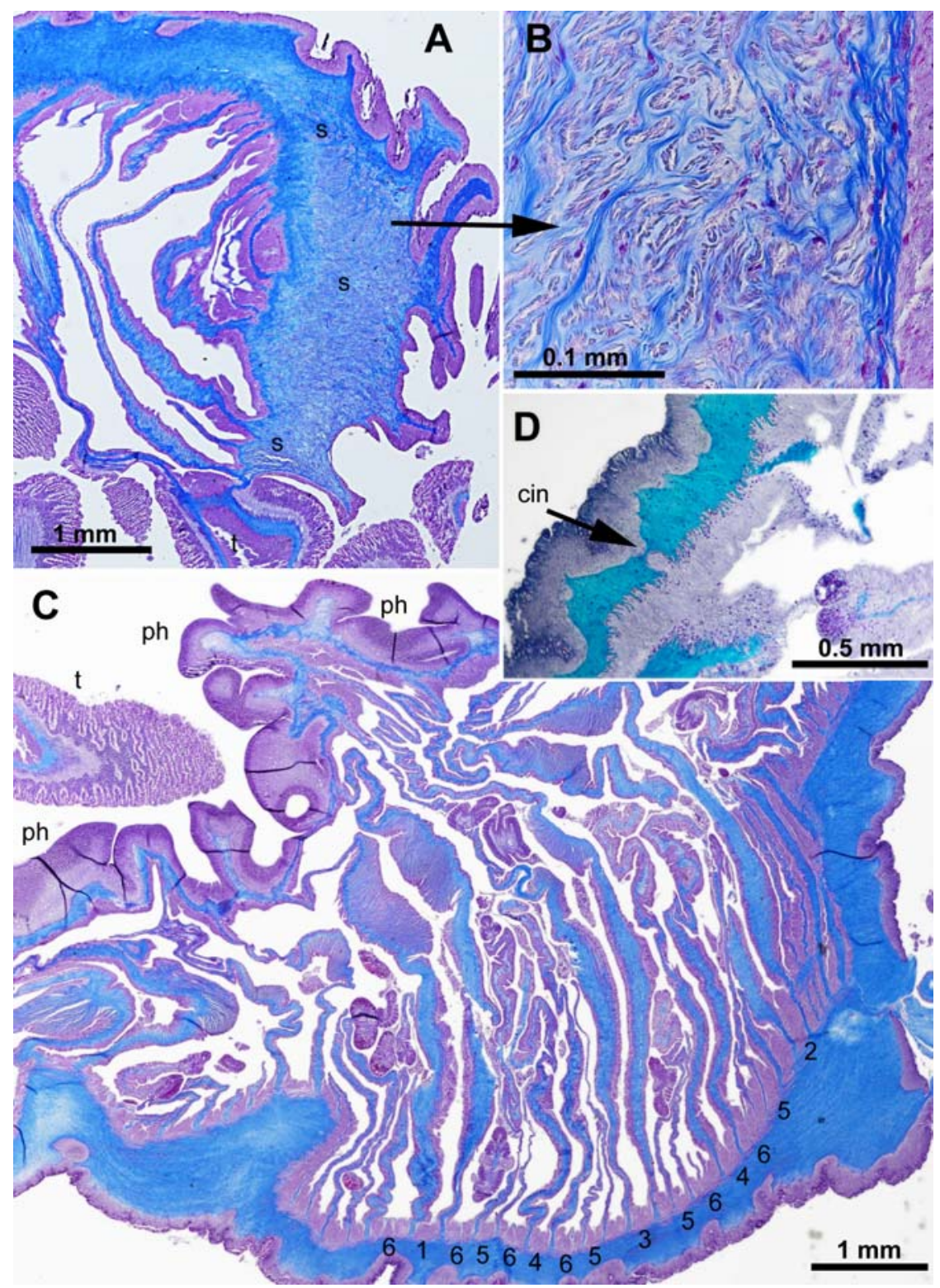

Fig. 13. Artemidactis victrix Stephenson, 1918, histological sections. A - longitudinal section though distal column showing mesogloeal sphincter; B - detail of the sphincter muscle under higher magnification; C transverse section through the column on the level of actinopharynx; D - transverse section of column showing a putative cinclide.

Abbreviations: cin — cinclide(?); ph — actinopharynx; $\mathrm{s}$ - marginal sphincter; $\mathrm{t}$ - tentacles; the numbers indicate the cycles of mesenterieal pairs.

Рис. 13. Artemidactis victrix Stephenson, 1918, гистологические срезы. А - продольный срез через дистальную часть колюмна, показывающий мезоглеальный сфинктер; В - участок сфинктера, увеличено; C - поперечный срез через колюмн на уровне актинофаринкса; D - поперечный срез через колюмн, показывающий предполагаемую цинклиду.

Обозначения: cin — цинклида(?); ph — актинофаринкс; s - маргинальный сфинктер; $\mathrm{t}$ - щупальца; цифрами обозначены номера циклов пар мезентериев. 
Table 4. Size ranges (length $\times$ width, in microns) and distribution of cnidae of Artemidactis victrix (measured in seven specimens). Letters in brackets correspond to letters in Fig. 14.

Таблица 4. Размеры (длина $\times$ ширина, в микронах) и распределение стрекательных капсул Artemidactis victrix (по семи экземплярам). Буквы в скобках соответствуют буквам на рис. 14.

\begin{tabular}{|c|c|c|}
\hline Body region & Cnidae & Size ranges $(\mu \mathrm{m})$ \\
\hline Column & $\begin{array}{l}\text { (A) basitrichs (rare) } \\
\text { (B) basitrichs (few) }\end{array}$ & $\begin{array}{c}10-14 \times 1.5-2 \\
18-26 \times 2-3\end{array}$ \\
\hline Tentacles & $\begin{array}{l}\text { (C) gracile spirocysts (numerous) } \\
\text { (D) robust spirocysts (numerous) } \\
\text { (E) basitrichs (common) } \\
\text { (F) p-mastigophores B2a (common) }\end{array}$ & $\begin{array}{c}27-45 \times 2.5-4 \\
25-44 \times 3.5-5.5 \\
(18) 23-29 \times 2.5-3 \\
30-40 \times 5-5.5\end{array}$ \\
\hline Actinopharynx & $\begin{array}{c}\text { (G) basitrichs (numerous) } \\
\text { (H) basitrichs (rare) } \\
\text { (I) p-mastigophores A (common) } \\
\text { (J) p-mastigophores B2a (common) }\end{array}$ & $\begin{array}{c}14-21 \times 1.5-2 \\
30-38 \times 3 \\
27-35 \times 4-7 \\
39-51 \times 5-6\end{array}$ \\
\hline Filaments & $\begin{array}{c}\text { (K) basitrichs (common) } \\
\text { (L) basitrichs (rare) } \\
\text { (M) p-mastigophores B1 (common) } \\
\text { (N) p-mastigophores B2a (very rare) } \\
\text { (O) p-mastigophores B2a (rare) }\end{array}$ & $\begin{array}{l}12-20 \times 1.5-2 \\
22-26 \times 3 \\
12-17 \times 4-5 \\
18-25 \times 4-4.5 \\
30-44 \times 5-6.5\end{array}$ \\
\hline Acontia & $\begin{array}{c}\text { (P) basitrichs (few) } \\
\text { (Q) basitrichs (numerous) } \\
\text { (R) p-mastigophores B2a (numerous) }\end{array}$ & $\begin{array}{c}15-25 \times 2-2.5 \\
45-58 \times 3-4.5 \\
61-85 \times 6-7 \\
\end{array}$ \\
\hline Pedal disc & $\begin{array}{c}\text { (S) basitrichs (common) } \\
\text { (T) basitrichs (common) } \\
\text { (U) p-mastigophores B2a (common) }\end{array}$ & $\begin{array}{c}10-15 \times 1.5-2 \\
(16) 20-26 \times 2.5-3 \\
16-21 \times 4-5\end{array}$ \\
\hline Limbus & $\begin{array}{c}\text { (V) basitrichs (common) } \\
\text { (W) basitrichs (common) } \\
\text { (X) p-mastigophores B2a (common) } \\
\text { (Y) holotrichs (common) }\end{array}$ & $\begin{array}{c}11-15 \times 1.5-2 \\
20-27 \times 2.5-3 \\
15-21 \times 4-4.5 \\
20-26 \times 4-5\end{array}$ \\
\hline Margin & $\begin{array}{c}\text { (Z) basitrichs (few) } \\
(\mathrm{ZZ}) \text { p-mastigophores B2a (numerous) }\end{array}$ & $\begin{array}{c}12-19 \times 1.5-2.5 \\
22-34 \times 4-5\end{array}$ \\
\hline
\end{tabular}

fewer than in the proximal and the distal parts of the column. Up to six cycles of mesenteries present proximally, the sixth cycle is incomplete. In the middle part of the column up to five cycles of mesenteries are present. In most distal part of the column small mesenteries of the sixth cycle are present. Mesenteries of first three cycles are perfect and have better developed retractors (Fig. 13C). The parietobasilar muscles are weak and have no free flaps. There are no oral or marginal stomata. Cinclides are not visible externally on living or preserved specimens, but they are obviously present: one specimen had an acontium emitted through the body wall and on histological sections of column we found spots with very thin mesogloea (Fig. 13D).

Cnidom. Gracile and robust spirocysts, basitrichs, holotrichs (or heterotrichs?), p-mastigophores A, p-mastigophores B1 and p-mastigophores B2a (see Fig. 14 and Table 4 for size ranges and distribution).

An interesting feature is the presence of holotrichs (or heterotrichs?) on the limbus (Fig. $14 Y)$. They are present in a very narrow zone (1-2 $\mathrm{mm}$ in preserved specimens) and not occur on column above the limbus. P-mastigophores B2a (Fig.14ZZ) are extremely numerous in a narrow zone (about $2 \mathrm{~mm}$ width) on the margin and not present below. It is interesting to note 


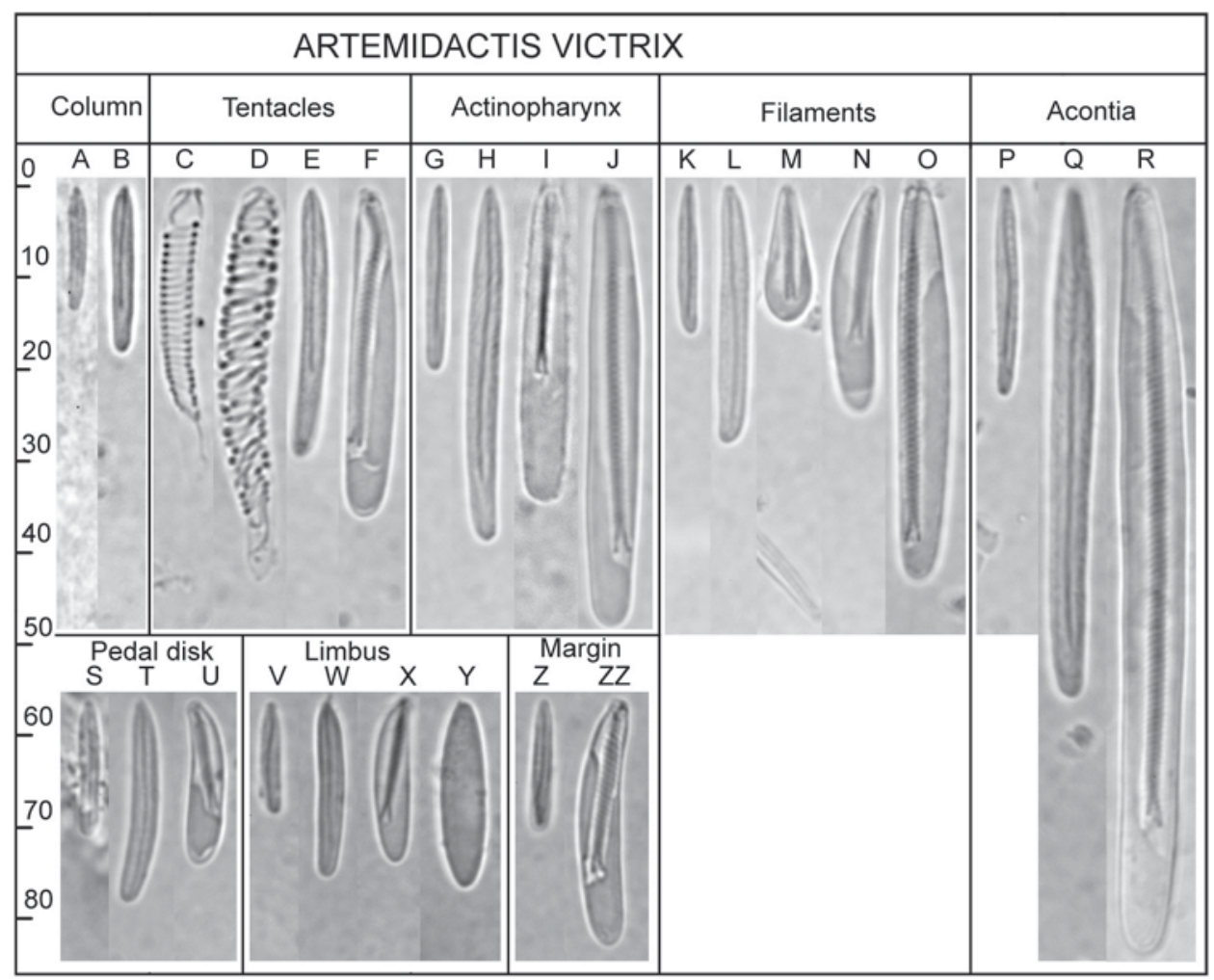

Fig. 14. Artemidactis victrix Stephenson, 1918, cnidom (see Table 4 for size ranges).

Рис. 14. Artemidactis victrix Stephenson, 1918, книдом (размеры указаны в табл. 4).

that the drop-shaped p-mastigophores B1 in filaments (Fig. 14M) are deeply stained by basic dyes in the same way as basitrichs, while all other p-mastigophores (as well as holotrichs and spirocysts) do not stain by basic dyes. The endoderm contains only few small basitrichs.

Spermatozoa $3.5-4 \times 1.5 \mu \mathrm{m}$, radially symmetrical, with tip head and wide mitochondrial complex (Fig. $31 \mathrm{C}$ ). The eggs are $0.3-0.8 \mathrm{~mm}$ in diameter.

Habitat. Collected specimens were attached to rocks and boulders. Inclination of the substratum varied between 0 and 90 degrees. One specimen was found attached on the kelp $\mathrm{Hi}$ mantothallus grandifolius.

Remarks. This is the most shallow-water record of the species, previously the species was known deeper than $75 \mathrm{~m}$ (Carlgren, 1949). The records of this conspicuous, large and apparently in some localities abundant species are surprisingly not numerous and widely separated: originally described by Stephenson (1918) from
Ross Sea it was then recorded from the Indian sector of Antarctica and from the opposite side of the Antarctic continent, near South Georgia, South Orkney Islands and in the Subantarctic between the Falkland Islands and Tierra Del Fuego (Carlgren, 1927, Carlgren, Stephenson, 1929, Carlgren, 1939). Recorded depths are from 5 to $437 \mathrm{~m}$.

The anatomy of this species is well known, original Stephenson's (1918) and subsequent Carlgren's (1927) descriptions are very detailed and precise. Our specimens conform well with these descriptions. Stephenson (1918: 46) says the sphincter in this species "is neither reticular nor alveolar". In the specimen we dissected the sphincter is reticular in its most distal end (near the tentacles), but otherwise its structure agrees with that described by Stephenson (1918) (see Fig. 13A, B).

One of the most characteristic feature of this species, allowing easy identification on underwater photographs, is a peculiar appearance of 

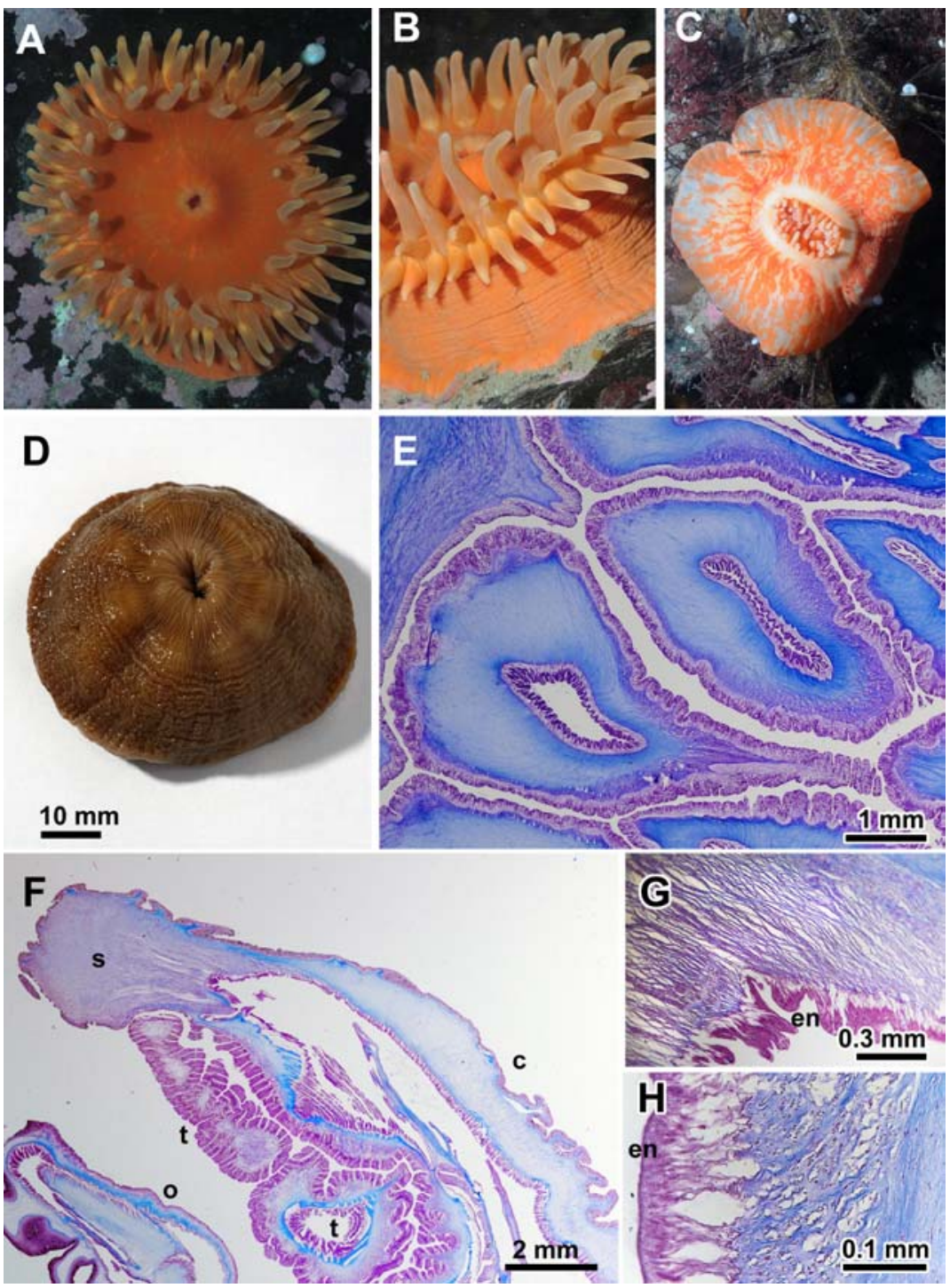

Fig. 15. Hormosoma scotti Stephenson, 1918. A — living specimen, note numerous embryos visible inside the tentacles; B - the same specimen from the side; $\mathrm{C}$ - specimen from ARD showing blotched colouration of the column; D - preserved specimen; E - transverse section through the tentacles at their bases, note thicker mesogloea on aboral sides of the tentacles and stronger musculature on the oral sides; $\mathrm{F}$ longitudinal section of distal column to show marginal sphincter muscle; $\mathrm{G}$ - detail of reticular part of the mesogloeal sphincter muscle; $\mathrm{H}$ - proximal part of the sphincter muscle.

Abbreviations: c - column; en - endoderm; o - oral disc; s - marginal sphincter; $\mathrm{t}$ - tentacles.

Рис. 15. Hormosoma scotti Stephenson, 1918. А - живой экземпляр, видны многочисленные эмбрионы в щупальцах и в области орального диска; В — тот же экземпляр, вид сбоку; С — экземпляр из $\mathrm{ARD}$ с пятнистой окраской колюмна; D - фиксированный экземпляр; $\mathrm{E}$ - поперечный срез через основания щупалец, видна более толстая мезоглея на аборальной стороне щупалец и более сильная мускулатура на их оральной стороне; F - продольный срез через дистальную часть колюмна, показывающий мезоглеальный маргинальный сфинктер; $\mathrm{G}$ - увеличенный участок ретикулярной части сфинктера; $\mathrm{H}$ - проксимальная часть сфинктера.

Обозначения: c — колюмн; en — энтодерма; o — оральный диск; s — маргинальный сфинктер; $\mathrm{t}$ - щупальца. 
Table 5. Size ranges (length $\times$ width, in microns) and distribution of cnidae of Hormosoma scotti (measured in six specimens). Letters in brackets correspond to letters in Fig. 16. Large heterotrichs in tentacles (F) are extraordinary numerous at aboral side of bases of outer tentacles and absent in other places. Таблица 5. Размеры (длина $\times$ ширина, в микронах) и распределение стрекательных капсул Ногтоsoma scotti (по шести экземплярам). Буквы в скобках соответствуют буквам на рис. 16. Большие гетеротрихи в щупальцах (F) экстраординарно многочисленны на аборальной стороне оснований внешних щупалец и отсутствуют в других местах.

\begin{tabular}{|l|c|c|}
\hline Body region & Cnidae & Size ranges $(\mu \mathrm{m})$ \\
\hline \multirow{3}{*}{ Pedal disc } & basitrichs (rare) & $12-14 \times 2-3$ \\
& basitrichs (few) & $16-24 \times 4-5$ \\
& heterotrichs (rare) & $17-23 \times 4.5-7$ \\
\hline \multirow{2}{*}{ Column } & (B) basitrichs (common) & $19-26 \times 3.5-5$ \\
& (C) heterotrichs (few) & $19-28 \times 5-7.5$ \\
\hline \multirow{2}{*}{ Margin } & (A) basitrichs (few) & $12-15 \times 2-3$ \\
& heterotrichs (few) & $19-22 \times 6$ \\
\hline \multirow{3}{*}{ Tentacles } & (D) spirocysts (very numerous) & $23-70 \times 2.5-7$ \\
& (E) basitrichs & $21-31 \times 3.5-5.5$ \\
\hline Actinopharynx & (F) heterotrichs & $50-75 \times 8-9.5$ \\
\hline \multirow{2}{*}{ Filaments } & (G) p-mastigophores A (common) & $30-40 \times 4.5-7.5$ \\
\hline
\end{tabular}

the oral disc which almost always is hidden under the partially expanded actinopharynx. Stephenson (1918: 41-42) says that in his preserved specimens the actinopharynx is "puffed out" and that "the extruded part of the actinopharynx $[\ldots]$ forms two great rounded inflated lips, which are strongly and regularly ridged and furrowed". This condition, however, is not a result of fixation but characteristic for living specimens too (Fig. 12A).

Measurements of nematocyst provided by Carlgren (1927) are in good agreement with those of the present material but are incomplete (in particular, he does not provide data on nematocysts in filaments). Carlgren (1927) reports two sorts of basitrichs for column, but he not provide data for pedal disc, margin and limbus where we found additional types of nematocysts ( $p$-mastigophores and holotrichs or heterotrichs). The presence of holotrichs or heterotrichs on the limbus is probably more common feature in Actiniaria than it reflected in the literature (see Isosicyonis alba below and Sanamyan et al., 2013). The presence of p-mastigophores A in the actinopharynx (Fig. 14 I) agrees with the position of the species in family Sagartiidae, the members of which contain p-mastigophores A (see Schmidt, 1972a).

Family Actinostolidae Carlgren, 1893

Hormosoma scotti Stephenson, 1918 Table 5; Figs. 15-16, 31B.

Hormosoma scotti Stephenson, 1918: 29. Carlgren, 1927: 47. Carlgren, Stephenson, 1929: 21. Dunn, 1983: 30 (and synonymy). Rodríguez, López-González, 2013: 51.

Hormosoma violaceum Pax, 1922: 82.

Actinostola rufostriata Pax, 1922: 85.

Material examined. ARD, 2010-02-14-(155), three specimens. SHO, 2011-02-06-(03), $31 \mathrm{~m}$, two specimens, 2011-02-22-(06), 25-35m, three specimens; 2011-02-26(11), $33 \mathrm{~m}$, one specimen. RAS, 2011-02-21-(28), $38 \mathrm{~m}$, one juvenile specimen.

Description. External and internal anatomy and histology. Preserved specimens are strongly contracted, the tentacles are hidden (Fig. 15D). The largest preserved specimen is $80 \mathrm{~mm}$ in basal diameter and $27 \mathrm{~mm}$ in height. Even smallest juvenile specimens (about 6-8 mm with only 48 tentacles and mesenteries) have characteristic large and numerous nematocysts on the aboral side of the bases of the outer tentacles and could be easily identified. 


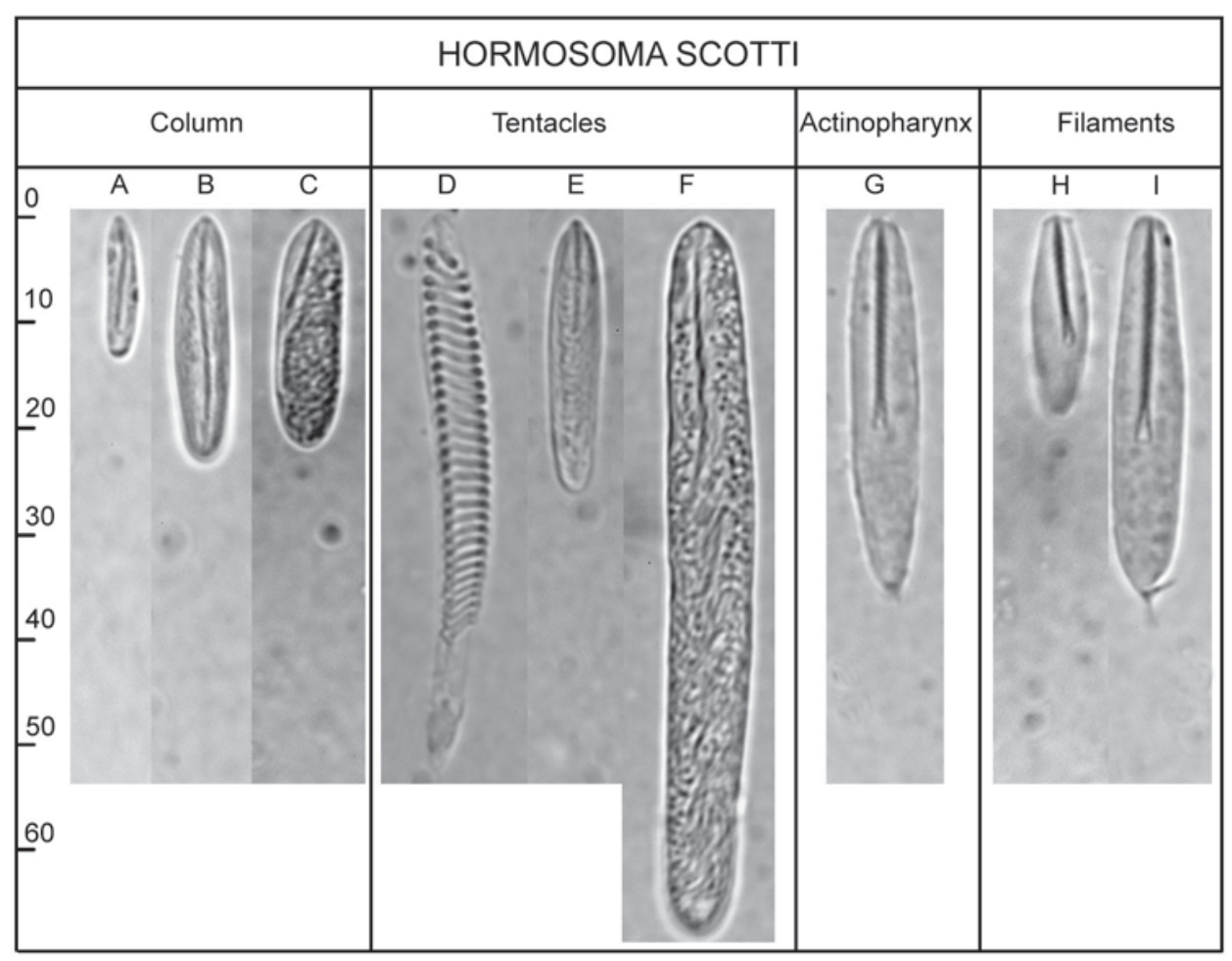

Fig. 16. Hormosoma scotti Stephenson, 1918, cnidom (see Table 5 for size ranges).

Рис. 16. Hormosoma scotti Stephenson, 1918, книдом (размеры указаны в табл. 5).

Very strong, mostly reticular (Fig. 15G), mesogloeal sphincter muscle fills whole thickness of mesogloea in distal end of column and forms collar in contracted specimens (Fig. 15F). In its proximal part the sphincter extends along endodermal side of mesogloea and is not separated from endodermal circular muscles (Fig. $15 \mathrm{H})$. There are no oral or marginal stomata.

The mesogloea is significantly (1.5-3 times) thicker and mesogloeal longitudinal muscles are much weaker on aboral sides of the bases of the tentacles, and longitudinal muscles almost disappear in the region of nematocyst battery (Fig. 15E).

Cnidom. Spirocysts, basitrichs, heterotrichs, p-mastigophores A (see Fig. 16 and Table 5 for size ranges and distribution).

Three types of nematocysts are present in the ectoderm of the pedal disc: small and large basitrichs and small heterotrichs (Table 5). In most part of column (from limbus to margin) two types of nematocysts are present: large basitrichs and small heterotrichs (Fig. 16B, C).
In a narrow zone $(2 \mathrm{~mm})$ between the bases of the tentacles and margin (hidden in preserved specimens) and in the bases of tentacles (1.3 $\mathrm{mm}$ ) and on periphery of oral disc only small basitrichs and small holotrichs are present (Fig. 16A, C). Large heterotrichs (Fig. 16F) form batteries on the small area (about $1.5 \mathrm{~mm}$ ) of the aboral side of the bases of outer tentacles (for the reasons why these nematocysts are referred here as heterotrichs rather than b-mastigophores are explained below, in 'Remarks' of Stomphia selaginella). Smaller nematocyst in tentacles (Fig. 16E) resemble large heterotrichs in batteries (Fig. 16F) but they have apical flaps (although we failed to find fired capsules of this type to finally confirm this), they stain by basic dyes and are probably basitrichs. They occur also in a narrow zone $(2-3 \mathrm{~mm})$ on the oral disc just above the tentacles. Numerous spirocysts are present on the oral disc. Spirocysts are present only in ectoderm of oral disc and tentacles. In macerated samples of other tissues spirocysts may occur as contaminants (confirmed 
on histological sections). Small p-mastigophores A in filaments (Fig. 16H) occur only in digestive region near cnidoglandular tracts. Endoderm of other regions contains no cnidae.

Spermatozoa $4 \times 1.5 \mu \mathrm{m}$, radially symmetrical, tip headed (Fig. 31B). The eggs are $0.7-1$ $\mathrm{mm}$ in diameter.

Habitat. In Fildes Bay the species were found mainly in depths below $20 \mathrm{~m}$ on hard substrates.

Remarks. Our specimens conform well to the original (Stephenson, 1918) and subsequent (Carlgren, Stephenson, 1929; Dunn, 1983; Rodríguez, López-González, 2013) descriptions. According to Dunn (1983) the wall thickness of the tentacles is equal on all sides, this is correct for the most part of the length of the tentacles but in our material the mesogloea is thickened on aboral sided of the tentacle bases.

Rodríguez, López-González (2013) reported spirocysts in the pedal disc, column and actinopharynx and Dunn (1983) reported them in actinopharynx and filamens. Spirocysts in these regions, according our data, are contaminants. Small heterotrichs in the pedal disc and column were not reported before for this species.

Stomphia selaginella (Stephenson, 1918) Table 6; Figs. 17-18.

Cymbactis selaginella Stephenson, 1918: 36.

Stomphia selaginella: Stephenson, 1920: 559. Rodríguez, López-González, 2013: 55 (and synonymy).
Cymbactis frigida Pax, 1922: 80.

Material examined. RAS, 2011-02-15-(12), 25-35 $\mathrm{m}$, one specimen (female); 2011-02-15-(13), 25-35 m, one juvenile specimen.

Description. External and internal anatomy and histology. Both specimens are small, the larger one is $14 \mathrm{~mm}$ in height and $18 \mathrm{~mm}$ in diameter, smaller one is $5 \mathrm{~mm}$ in height and diameter. The tentacles (58 and 37 in number) are expanded in preserved specimens (Fig. 17C). They are arranged in four cycles. Living specimens have a characteristic colour pattern with radial orange markings on the disc and rather long, tapering, pointed tentacles with two transverse orange bands (Fig. 17A, B). Both specimens have a well marked margin (Fig. 17D, arrow). Strong mesogloeal alveolar marginal sphincter muscle runs along endodermal side of the mesogloea and not separated from circular endodermal muscles (Fig. 17E, F). Longitudinal muscles of the tentacles and the oral disc are mesogloeal.

Cnidom. Spirocysts, basitrichs, heterotrichs, p-mastigophores A (see Fig. 18 and Table 6 for size ranges and distribution).

The nematocysts at the limbus are the same as in the column (basitrichs only). Oral disc and margin near the bases of outer tentacles have numerous spirocysts and basitrichs as in tentacles.

Remarks. Large nematocysts in the tentacles referred as b-mastigophores by previous authors (e.g. Carlgren, 1949; Fautin, 1984; Rodríguez, López-González, 2013) are present

Table 6. Size ranges (length $\times$ width, in microns) and distribution of cnidae of Stomphia selaginella (measured in two specimens). Letters in brackets correspond to letters in Fig. 18.

Таблица 6. Размеры (длина $\times$ ширина, в микронах) и распределение стрекательных капсул Stomphia selaginella (по двум экземплярам). Буквы в скобках соответствуют буквам на рис. 18.

\begin{tabular}{|l|c|c|}
\hline Body region & Cnidae & Size ranges $(\mu \mathrm{m})$ \\
\hline Pedal disc & basitrichs (few) & $14-19 \times 2-2.5$ \\
\hline Column & (A) basitrichs (common) & $18-21 \times 2-2.5$ \\
\hline \multirow{2}{*}{ Tentacles } & (B) spirocysts (very numerous) & $26-50 \times 3-6$ \\
& (C) basitrichs (common) & $15-28 \times 2-2.5$ \\
\hline \multirow{2}{*}{ Actinopharynx } & (D) heterotrichs (few) & $32-48 \times 5-7.5$ \\
\hline \multirow{2}{*}{ Filaments } & (E) basitrichs (common) & $23-33 \times 2-3$ \\
& (F) p-mastigophores A (few) & $21-26 \times 4-6$ \\
\hline
\end{tabular}



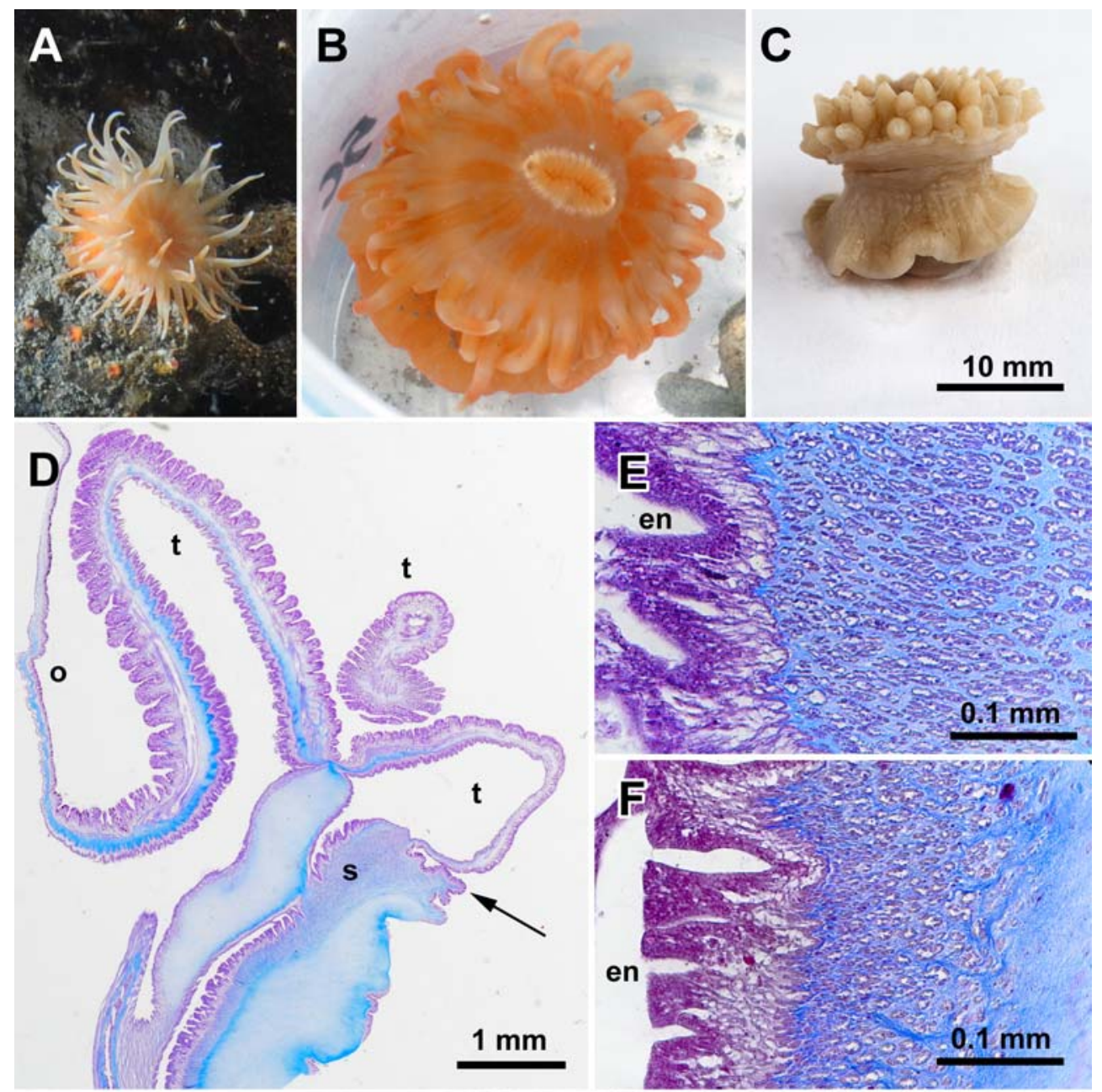

en
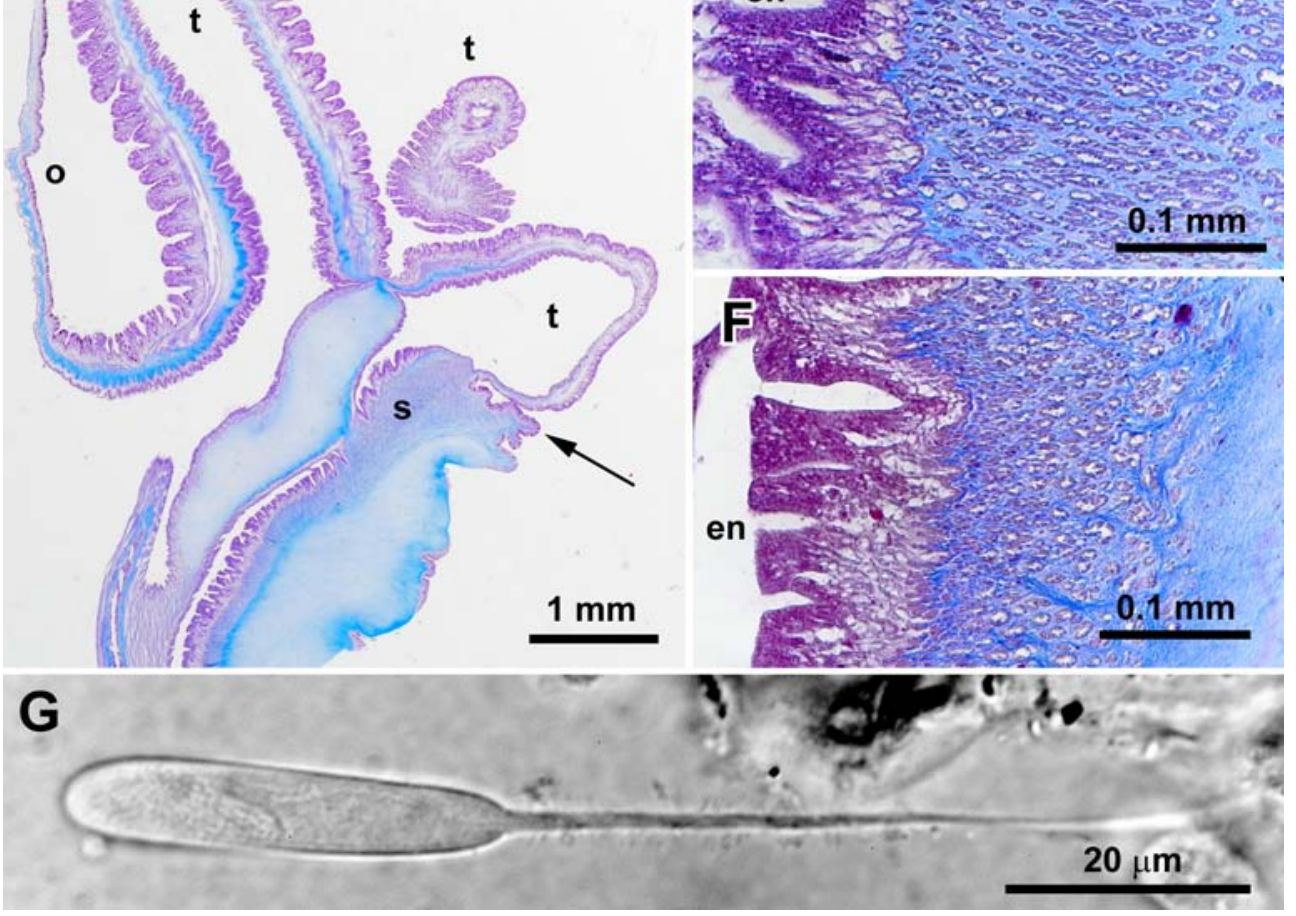

Fig. 17. Stomphia selaginella (Stephenson, 1918). A-B - living specimens; C - preserved specimen; D longitudinal section of distal column (arrow indicates margin); $\mathrm{E}$ - distal part of the sphincter; $\mathrm{F}$ - proximal part of the sphincter; $\mathrm{G}$ - large heterotrich from ectoderm of the tentacle, exploded.

Abbreviations: en - endoderm; o - oral disc; $\mathrm{s}$ - marginal sphincter; $\mathrm{t}$ - tentacles.

Pис. 17. Stomphia selaginella (Stephenson, 1918). A-B - живые экземпляры; С - фиксированный экземпляр; D - продольный срез через дистальную часть колюмна (стрелкой указан маргинальный выступ колюмна); Е - дистальная часть сфинктера; F - проксимальная часть сфинктера; $\mathrm{G}$ большой гетеротрих из эктодермы щупальца, в выстреленном состоянии.

Обозначения: en - энтодерма; о - оральный диск; s — маргинальный сфинктер; $\mathrm{t}$ - щупальца. 


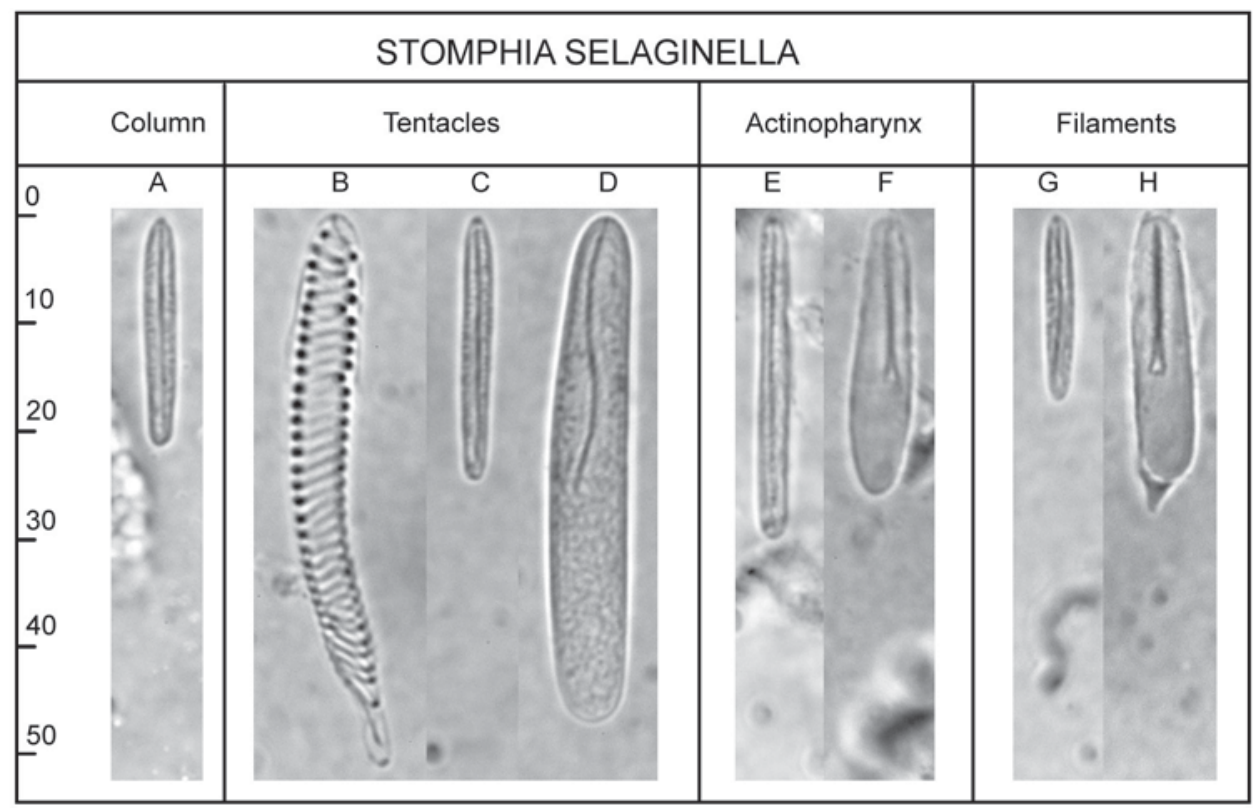

Fig. 18. Stomphia selaginella (Stephenson, 1918), cnidom (see Table 6 for size ranges).

Рис. 18. Stomphia selaginella (Stephenson, 1918), книдом (размеры указаны в табл. 6).

along the whole length of all tentacles (not only in distal parts as stated by Carlgren, 1949 and not only at base of outer tentacles as reported by Rodríguez \& López-González, 2013). This capsule has no well defined shaft. The basal part of its fired tubule gradually diminishes in diameter (Fig. 17G), while mastigophores have a well defined cylindrical shaft, of the same diameter throughout (Mariscal, 1974; England, 1991). This capsule is not a heteroneme, it is an anisorhiza haploneme (Mariscal, 1974; Bozhenova, 1988). The tubule of this capsule is spiny throughout and the spines are larger at its basal portion (about $2 \mu \mathrm{m}$ ) (heterotrichous anisorhiza haploneme according to Mariscal, 1974), and thus we refer it as heterotrich. It differs from basitrichs by absence of apical flaps. Heterotrichs of $S$. selaginella (as well as heterothichs of Hormosoma scotti) are stained by basic dyes.

Family Actiniidae Rafinesque, 1815

\section{Glyphoperidium bursa Roule, 1909}

Table 7; Figs. 19-20, 31M.

Glyphoperidium bursa Roule, 1909: 11. Carlgren, 1927: 34; 1928: 166. Dunn, 1983: 26 (and synonymy). Rodríguez, López-González, 2013: 23.
Glyphoperidium vas Roule, 1909: 13.

Epiactis stephensoni Pax, 1922: 79.

Material examined. ESC, 2011-02-01-(10), 9 m, one specimen (Fig. 19B). RAS, 2010-02-11-(89), two specimens; 2010-02-12-(41), two specimens; 2010-02-13-(1), one specimen; 2011-02-21-(14), one specimen. SHO, 201102-22-(07), one specimen.

Description. External and internal anatomy and histology. The largest preserved specimen in the present collection is $62 \mathrm{~mm}$ diameter and $40 \mathrm{~mm}$ high, the smallest $17 \mathrm{~mm}$ diameter and $7 \mathrm{~mm}$ high. Living specimens could be easily recognized on the photos by overall habitus (Fig. 19A), they have a thick short red column and very numerous rather long and flexible tentacles of the same reddish tint as column but paler. The surface of the column of living specimens is usually at least in part covered by fine sediment which is not retained on preserved specimens. The shape of some preserved specimens from the present collection is also very distinctive (Fig. 19B), the oral disc is often not contracted and up to two times wider than the pedal disc. The fosse is small, up to 2 $\mathrm{mm}$ in depth. The capitulum is not developed (Fig. 19D).

The mesenteries are more numerous distally than proximally. The specimen from RAS (\#2010-02-12-(41)) had 551 tentacles and 332 

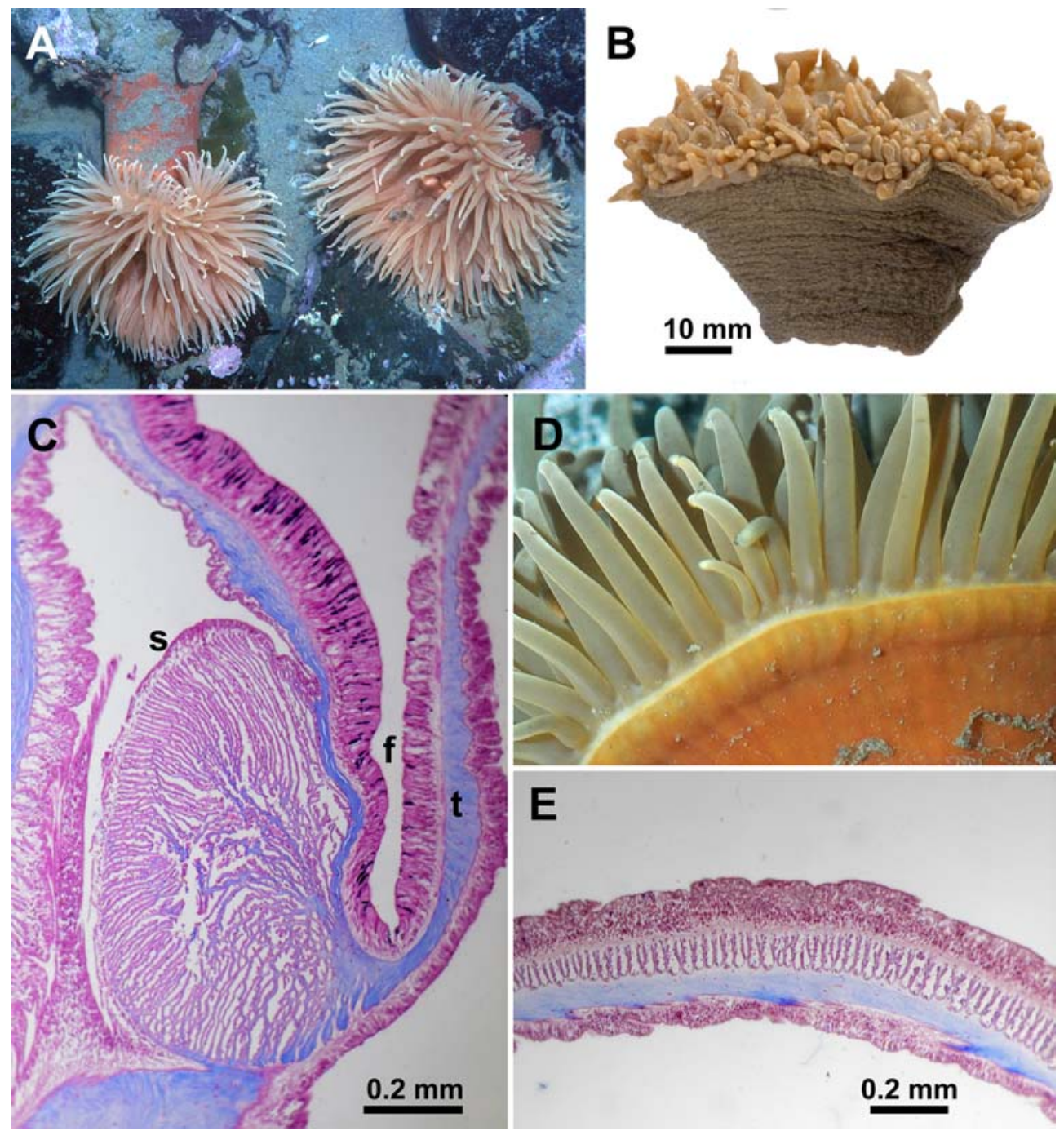

Fig. 19. Glyphoperidium bursa Roule, 1909. A — living specimens; B — formalin preserved specimen; $\mathrm{C}$ - marginal sphincter; D - margin of living specimen, note the absence of capitulum; E - ectodermal radial muscles of the oral disc.

Abbreviations: $\mathrm{f}$ - fosse; $\mathrm{s}$ - marginal sphincter; $\mathrm{t}$ - tentacle.

Рис. 19. Glyphoperidium bursa Roule, 1909. А — живые экземпляры; В — фиксированный экземпляр; C - маргинальный сфинктер; D - маргин живого экземпляра, отметьте отсутствие капитулюма; E - эктодермальная радиальная мускулатура орального диска.

Обозначения: f — фосса; s — маргинальный сфинктер; $\mathrm{t}$ - щупальце.

mesenteries proximally. Another specimen from RAS (\#2010-02-11-(89)) has 338 tentacles, 194 mesenteries in the middle column and 204 mesenteries near the limbus. The specimen from ESC (\#2011-02-01-(10), Fig. 19B) has 374 tentacles, 250 mesenteries in the upper part of column ( $5 \mathrm{~mm}$ below the parapet), 200 mesen- teries in the middle part of column and 250 near the limbus. Mesenteries of the last cycle are very small and present only in margin.

The endodermal marginal sphincter small, circumscribed or partly diffuse, situated at the bottom of the fosse and has thin central lamella which is not always clear (Fig. 19C). The longi- 
Table 7. Size ranges (length $\times$ width, in microns) and distribution of cnidae of Glyphoperidium bursa (measured in four specimens). Letters in brackets correspond to letters in Fig. 20. Таблица 7. Размеры (длина $×$ ширина, в микронах) и распределение стрекательных капсул Glyphoperidium bursa (по четырем экземплярам). Буквы в скобках соответствуют буквам на рис. 20.

\begin{tabular}{|l|c|c|}
\hline Body region & Cnidae & Size ranges $(\mu \mathrm{m})$ \\
\hline Column & (A) basitrichs (common) & $20-27 \times 2-3$ \\
\hline Tentacle bases & (B) spirocysts (rare) & $25-30 \times 3-4$ \\
& (C) basitrichs (common) & $21-29 \times 2-2.5$ \\
\hline \multirow{2}{*}{ Tentacle tips } & (D) spirocysts (very numerous) & $20-41 \times 2-4$ \\
& (E) basitrichs (common) & $35-48 \times 2-2.5$ \\
\hline Actinopharynx & (F) basitrichs (common) & $34-41 \times 2-3$ \\
\hline \multirow{2}{*}{ Filaments } & (G) basitrichs (rare) & $14-21 \times 2-2.5$ \\
& (H) basitrichs (few) & $30-40 \times 3-5.5$ \\
& (I) p-mastigophores A (common) & $25-35 \times 4-6$ \\
\hline
\end{tabular}

tudinal muscles of the tentacles and radial muscles of the oral disc are ectodermal (Fig. 19E). The mesenteries have both oral (up to $5 \mathrm{~mm}$ diameter) and marginal (up to $1 \mathrm{~mm}$ diameter) stomata.

Cnidom. Spirocysts, basitrichs, p-mastigophores A (see Fig. 20 and Table 7 for size ranges and distribution).

The basitrichs in pedal disc, limbus, column, fosse (where they are more numerous), bases of the tentacles and oral disc are of the same type and size range. The basitrichs in the tips of the tentacles are larger than at the tentacle bases. The ectoderm of the oral disc contains spirocysts. The small basitrichs in filaments are present only in the digestive region (sensu Stephenson, 1928, Fig.18B), while the cnidoglandular tract contains only large basitrichs and p-mastigophores A.

Spermatozoa 3-4 × 1-1.5 $\mu \mathrm{m}$, bilaterally symmetrical, with blunt head (Fig. 31M).

Habitat. Species very common on boulders in depths from 6 to $10 \mathrm{~m}$ at ESC.

Remarks. Glyphoperidium bursa is probably the largest, most common and well known Antarctic species (see Dunn, 1983; Rodríguez, López-González, 2013).

According to literature the number of tentacles may exceed 2000 (Dunn, 1983) or even estimated to 3500 (Rodríguez, López-González, 2013). Our specimens are smaller than those reported by these authors and have less numerous tentacles. The relative number of mesenteries proximally and distally in our specimens is in good agreement with the data provided by Carlgren (1927) and Dunn (1983) who stated that G. bursa has more mesenteries distally than proximally. Rodríguez, López-González(2013: 27) however wrote that according to Carlgren (1927) "specimens of G. bursa have the same number of mesenteries distally and proximally but fewer at the actinopharynx level" but this statement is not correct. Carlgren (1927) clearly stated (in the diagnosis of the genus and in the description of the species) that the mesenteries are more numerous distally. In one specimen he found 96 pairs ( 5 cycles) in greater part of the body, and this specimen had two additional cycles in uppermost region (i.e.7 cycles of mesenteries distally, although the latest cycle probably incomplete) and some additional mesenteries of the sixth order in most proximal part. In the diagnosis of the species Rodríguez, LópezGonzález (2013: 23) stated that the "mesenteries arranged to nine cycles according to the number of tentacles", but this does not agree with the number of tentacles reported by these authors (about 3500). If the specimen has 3500 tentacles it must have tenth cycle of mesenteries at margin (nine cycles assumes that no more than 3072 tentacles are present). Also according to Rodríguez, López-González (2013) the column is divided into scapus and capitulum. In our specimens the capitulum is not present, outer tentacles arise directly from the bottom of the fosse (Fig. 19C, D). According to Carlgren (1927) longitudinal muscles of the tentacles are ectodermal, radial muscles of the oral disc meso- 


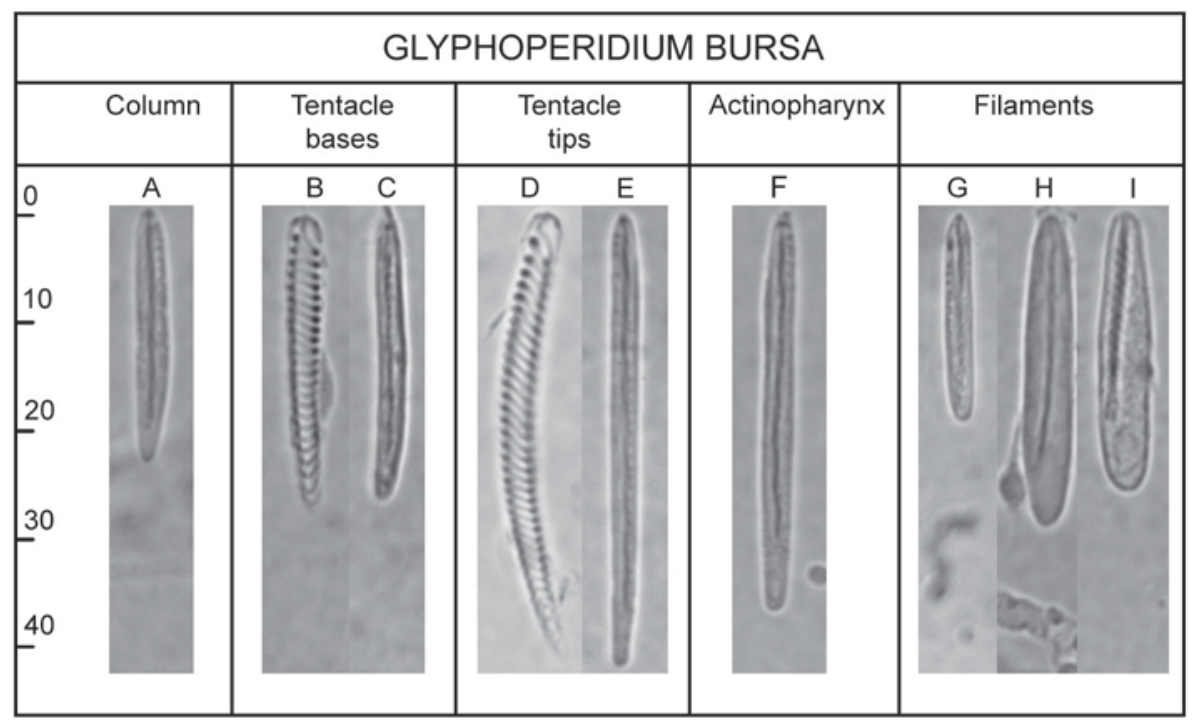

Fig. 20. Glyphoperidium bursa Roule, 1909, cnidom (see Table 7 for size ranges).

Pис. 20. Glyphoperidium bursa Roule, 1909, книдом (размеры указаны в табл. 7).

ectodermal to ecto-mesogloeal. According to Dunn (1983) longitudinal muscles of the tentacles are meso-ectodermal to ectodermal. In our specimens both longitudinal muscles of the tentacles and radial muscles of oral disc are ectodermal (Fig. 19E).

Types and size ranges of cnidae of the present specimens correspond to data given by Dunn (1983) and Carlgren (1945), but nematocyst signature of $G$. bursa provided by Rodríguez, López-González (2013: 25-26 and Fig. 11) differs in some points. In particular, b-mastigophores reported by these authors in the tentacles and actinopharynx are immature basitrichs (note the same number of spiral turns in armed part of tubule in capsules on Fig. $11 \mathrm{E}$ and $\mathrm{F}$ in the tentacles and Fig. $11 \mathrm{G}$ and $\mathrm{H}$ in the actinopharynx, see Rodríguez, López-González, 2013). Bmastigophores reported by these authors in filaments (Fig. $11 \mathrm{~K}$ ) are also referred here as basitrichs: they has six to eight spiral turns in armed part of the tubule and stain by basic dyes as typical basitrichs. Small basitrichs in the tentacles (Rodríguez, López-González, 2013, Fig. 11D) are probably contaminants from the endoderm.

According to Carlgren (1949) the monotypic genus Glyphostylum Roule, 1909 could be congeneric with Glyphoperidium. Dunn (1983) strongly suspected that Glyphostylum calyx Roule, 1909 is conspecific with G. bursa, although she did not include $G$. calyx to the synonymy of this species. Another poorly known Antarctic actiniid species, Urticinopsis antarctica (Verrill, 1922), has numerous tentacles (more than 200 according to Carlgren, 1927) and thus may resemble smaller specimens of $G$. bursa, but Urticinopsis has more than twice the number of mesenteries proximally compared to tentacles, the opposite is the case for Glyphoperidium. Rest Antarctic actiniids have either less numerous tentacles or marginal structures and cannot be confused with G. bursa.

This is most shallow-water record for the species $(9 \mathrm{~m})$.

Isosicyonis alba (Studer, 1879)

Table 8; Figs. 21-23.

Paractis alba Studer, 1879: 545.

Isosicyonis alba: Carlgren, 1927: 52. Riemann-Zürneck, 1980: 24. Fautin, 1984: 9. Rodríguez, LópezGonzález, 2008: 80.

Paractis studerii Andres, 1883: 271.

Material examined. ARD, 2010-02-19-(233), $27 \mathrm{~m}$, one specimen, female (Fig. 21A, D).

Description. External and internal anatomy and histology. The sole collected specimen is $56 \mathrm{~mm}$ in largest diameter and $20 \mathrm{~mm}$ in 

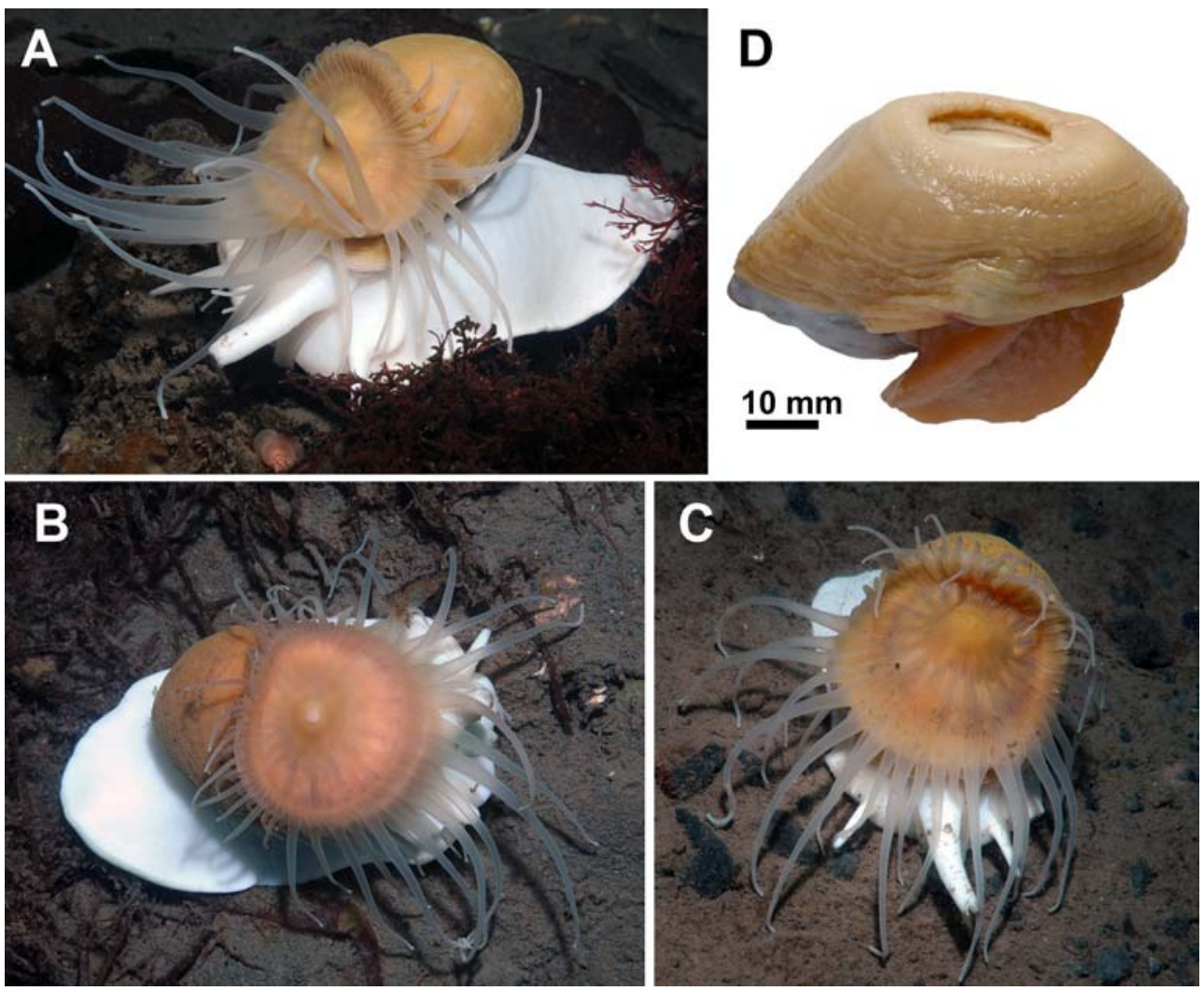

Fig. 21. Isosicyonis alba (Studer, 1879). A-C - living specimens in natural habitat, note that the tentacles directed to the head of mollusk are always longer than the rest; D - formalin preserved specimen attached to mollusk shell, side view.

Рис. 21. Isosicyonis alba (Studer, 1879). А-C - живые экземпляры в естественной среде обитания, щупальца, направленные к голове моллюска, всегда длиннее остальных; D - фиксированный экземпляр на раковине моллюска, вид сбоку.

height. The colour of living species is plain beige. Undisturbed expanded specimens show its peculiar position on the gastropod shell Harpovoluta charcoti (Lamy, 1910) (identified by Dr. A. Martynov): the anemone is oriented in such a way that the oral disc is tilted forward, facing in the direction of the movement of the mollusk. The long tentacles on the anterior half of the disc are directed forward, monitoring the space in front of mollusk's head and, in part, embracing it on the sides, while the tentacles on the posterior half of the disc are very short (Fig. $21 \mathrm{~A}, \mathrm{~B}, \mathrm{C})$. The number of tentacles counted on the photos of several living specimens varies from 61 to 80. They are arranged in two cycles, the tentacles of the inner cycle (endocoelic) are thicker and longer than the tentacles of outer cycle (exocoelic). The marginal sphincter is meso-endodermal (Fig. 22D). On the longitudinal sections it is much longer (up to $5 \mathrm{~mm}$ ) and thicker on the anterior side of the body (i.e. side oriented toward the head of mollusk) than on posterior side of the body (where it is about 1.7 $\mathrm{mm}$ long) (compare Figs. 22B and C). Longitudinal muscles of the tentacles and radial muscles of the oral disc are ectodermal (Fig. 22A).

Cnidom. Spirocysts, basitrichs, holotrichs (?), heterotrichs and p-mastigophores A (see Fig. 23 and Table 8 for size ranges and distribution). Small basitrichs on limbus (Fig. 23B) differ from small basitrichs of column (Fig. $23 \mathrm{~F}$ ) by shorter armed part of the tubule, which in unfired condition is not longer (usually shorter) than half length of the capsule. Heterotrichs 


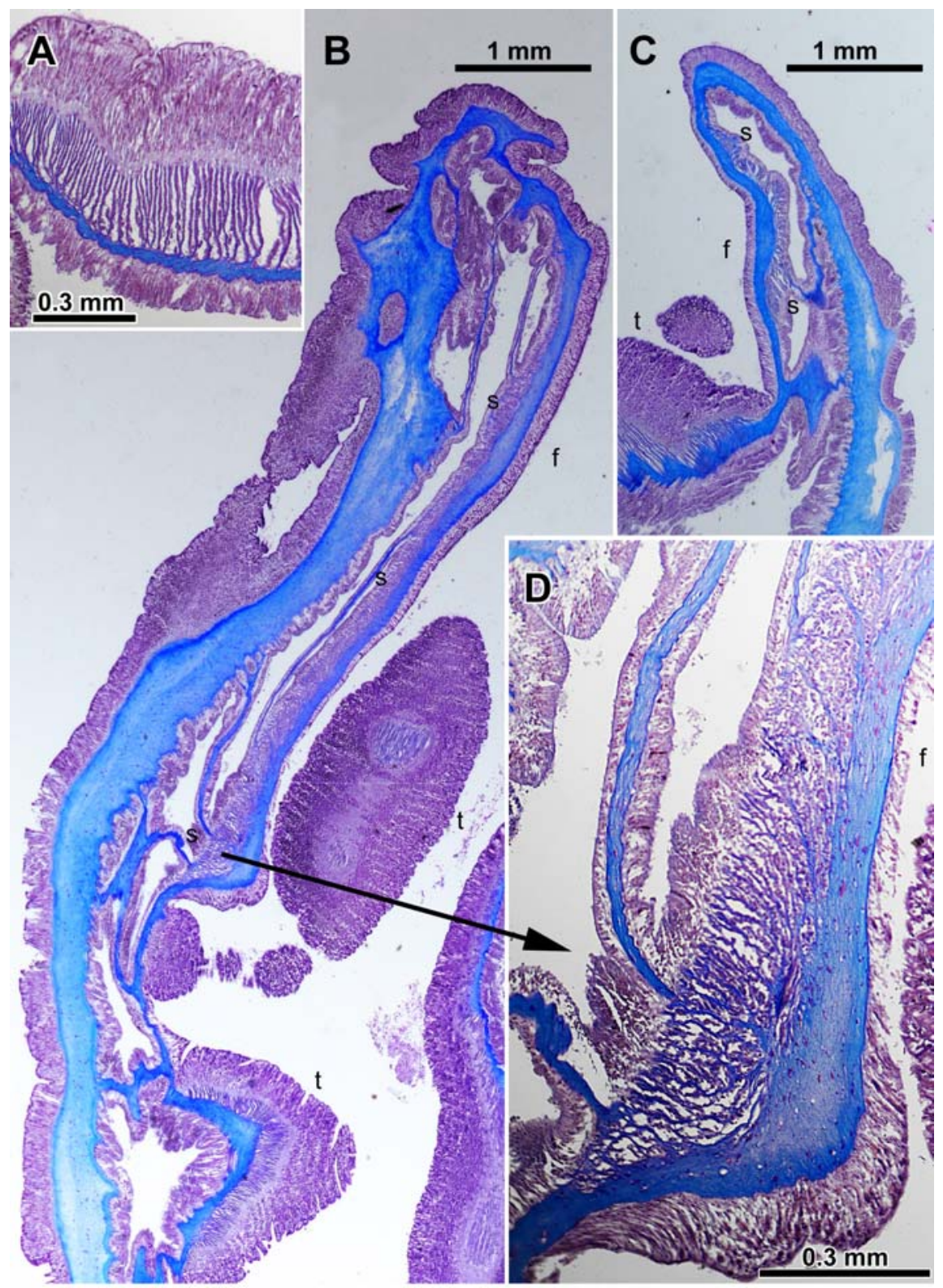

Fig. 22. Isosicyonis alba (Studer, 1879), histological sections. A — radial ectodermal muscles of the oral disc; B - longitudinal section though the anterior side of the distal column (i.e. side oriented toward the head of mollusk); C - longitudinal section though the posterior side of the distal column; D - a part of marginal sphincter near the bottom of the fosse, the anterior part of column, enlarged.

Abbreviations: $\mathrm{f}$ - fosse; $\mathrm{s}$ - marginal sphincter; $\mathrm{t}$ - tentacles.

Рис. 22. Isosicyonis alba (Studer, 1879), гистологические срезы. А - радиальные эктодермальные мускулы орального диска; В - продольный срез через переднюю сторону дистальной части колюмна (т.е. сторону, ориентированную к голове моллюска); С - продольный срез через заднюю сторону дистальной части колюмна; D - часть маргинального сфинктера около дна фоссы, передний конец колюмна, увеличено.

Обозначения: $\mathrm{f}$ - фосса; s - маргинальный сфинктер; $\mathrm{t}$ - щупальца. 
Table 8 . Size ranges (length $\times$ width, in microns) and distribution of cnidae of Isosicyonis alba (measured in one specimen). Letters in brackets correspond to letters in Fig. 23.

Таблица 8. Размеры (длина $×$ ширина, в микронах) и распределение стрекательных капсул Isosicyonis alba (по единственному экземпляру). Буквы в скобках соответствуют буквам на рис. 23.

\begin{tabular}{|c|c|c|}
\hline Body region & Cnidae & Size ranges $(\mu \mathrm{m})$ \\
\hline Pedal disc & basitrichs (common) & $20-28 \times 2-3$ \\
\hline Limbus & $\begin{array}{l}\text { (A) spirocysts (very rare) } \\
\text { (B) basitrichs (common) } \\
\text { (C) basitrichs (common) } \\
\text { (D) heterotrichs (common) }\end{array}$ & $\begin{array}{c}30-50(64) \times 2.5-4(4.5) \\
22-39 \times 2-4 \\
41-99 \times 3.5-6 \\
23-51 \times 5-10.5\end{array}$ \\
\hline Column & $\begin{array}{l}\text { (E) spirocysts (common) } \\
\text { (F) basitrichs (common) } \\
\text { (G) basitrichs (common) }\end{array}$ & $\begin{array}{c}30-75 \times 2-5 \\
21-35 \times 2-2.5 \\
(50) 75-121 \times 4-7\end{array}$ \\
\hline $\begin{array}{l}\text { Margin and oral } \\
\text { disc }\end{array}$ & $\begin{array}{l}\text { spirocysts (common) } \\
\text { basitrichs (rare) } \\
\text { basitrichs (common) }\end{array}$ & $\begin{array}{c}20-58 \times 2-5 \\
22-29 \times 2-3 \\
34-55 \times 3.5-5 \\
\end{array}$ \\
\hline Tentacles & $\begin{array}{l}\text { (H) spirocysts (numerous) } \\
\text { (I) basitrichs (very rare) } \\
\text { (J) basitrichs (numerous) } \\
\text { (K) holotrichs ? (very rare) }\end{array}$ & $\begin{array}{c}20-50 \times 2-5 \\
20-42 \times 1.5-3 \\
35-75 \times 3-5 \\
37-56 \times 7.5-10\end{array}$ \\
\hline Actinopharynx & $\begin{array}{l}\text { (L) spirocysts (very rare) } \\
\text { (M) basitrichs (very rare) } \\
\text { (N) basitrichs (numerous) }\end{array}$ & $\begin{array}{c}45-60 \times 3.5-5 \\
30-41 \times 3 \\
51-75 \times 4-5.5\end{array}$ \\
\hline $\begin{array}{l}\text { Cnidoglandular } \\
\text { tracts of filaments }\end{array}$ & $\begin{array}{c}\text { (O) basitrichs (rare) } \\
\text { (P) p-mastigophores A (few) } \\
\text { (Q) heterotrichs (few) }\end{array}$ & $\begin{array}{l}50-74 \times 2.5-5 \\
31-41 \times 4-5.5 \\
50-78 \times 5-7.5\end{array}$ \\
\hline Endoderm & (R) basitrichs & $19-34 \times 2-3$ \\
\hline
\end{tabular}

(Fig. 23D) are abundant directly on the limbus but become much sparse and quickly disappear distally. They have no apical flaps and do not stain with basic dyes. Fired tubule is about 1.5 $\mu \mathrm{m}$ in diameter. The spines on its basal portion are about $2.5 \mu \mathrm{m}$ long (i.e. two times shorter than in typical basitrichs), while on the rest part of the tubule the spines are not recognizable. Therefore the basal portion of the tubule in unfired capsule is thicker and looks as a stick 6$15 \mu \mathrm{m}$ in length. Sizes of large basitrichs of column (Fig. 23G) somewhat differ in proximal, middle and distal parts of column. In proximal column ( $5 \mathrm{~mm}$ above the limbus) they are larger $(98-121 \mu \mathrm{m})$ than in middle $(82-116 \mu \mathrm{m})$ and distal column $(75-102 \mu \mathrm{m})$. On the margin they are 35-55 $\mu \mathrm{m}$, and on the oral disc 34-50 $\mu \mathrm{m}$ (see Table 8). Nematocyst of the tentacles on the anterior and posterior sides of the disc are the same, but in the former we found several capsules tentatively identified as holotrichs (Fig. $23 \mathrm{~K}$ ) which are not found in other tentacles. The ectoderm of actinopharynx contains sporadic spirocysts (confirmed on histological sections). Small basitrich in filaments (Fig. 23R) are present only in the digestive region and in the endoderm of all other parts of the body, where they are sparser than in the filaments. P-mastigophores A in filaments (Fig. 23P) appear to have pointed rather than V-shaped end of the shaft. Nevertheless, this capsule is homologous to the usual pmastigophores A occurring in the filaments of other members of the family Actiniidae: it has thin wall, no apical flaps, about the same number of spiral turns on the shaft, but the transitional zone between the shaft and tubule is a bit longer than usual and V-shaped funnel is not formed. The capsule in filaments we name 


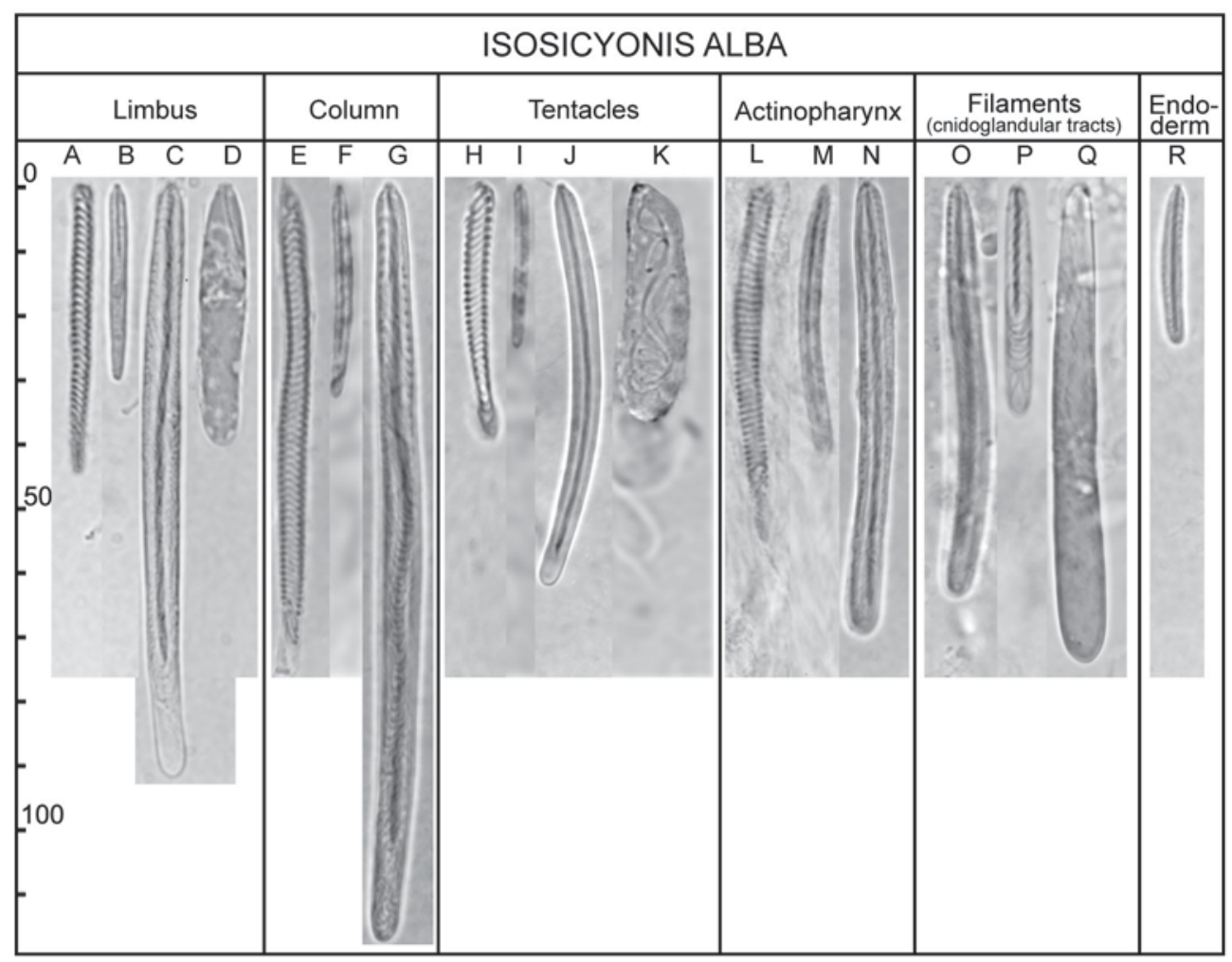

Fig. 23. Isosicyonis alba (Studer, 1879), cnidom (see Table 8 for size ranges).

Рис. 23. Isosicyonis alba (Studer, 1879), книдом (размеры указаны в табл. 8).

heterotrich (Fig. 23Q) was named previously as "b-mastigophore" (Riemann-Zürneck, 1980; Fautin, 1984; Rodríguez, López-González, 2008). This capsule is not a heteroneme. The diameter of its fired tubule gradually diminishes from the base to the end, thus it has no shaft. The spines on the basal part of the tubule are very short (shorter than $1 \mu \mathrm{m}$ ) that is several times shorter than basal spines in mastigophores and basitrichs. It differs from basitrichs by absence of apical flaps and, unlike basitrichs, it has no affinity to basic dyes.

Remarks. This is the most shallow-water record of the species, it was known previously from 84-928 m (Rodríguez, López-González, 2008). The species is known from numerous records in the SE Atlantic (off the Argentina coast) and from Antarctic locations (Antarctic Peninsula and islands, Weddell and Ross Sea) and the present record is within the known range.
Family Preactinidae England (in England et Robson), 1984

Dactylanthus antarcticus (Clubb, 1908) Table 9; Figs. 24-27, 31Q.

Cystiactis antarctica Clubb, 1908: 5.

Dactylanthus antarcticus: Carlgren, 1911: 2; 1940 : 19. Dunn, 1983: 2 (and synonymy). Dayton et al., 1997: 135. Capolla, Fautin, 2000: 995. Rodríguez, LópezGonzález, 2013: 40 (and synonymy).

Additional material examined. KBPGI 278/1, Chile, Canal Murray, $54^{\circ} 59^{\prime} \mathrm{S}, 68^{\circ} 21^{\prime} \mathrm{W}, 20-30 \mathrm{~m}$, two specimens.

Description (based on specimens from Chile). External and internal anatomy and histology. Two preserved specimens are 45-50 $\mathrm{mm}$ long and 15-16 $\mathrm{mm}$ diameter. The living specimens are very flexible, up to $30 \mathrm{~cm}$ long in expansion, whitish or beige, translucent, usually the tips of the columnar vesicles and the tentacles are white (Fig. 24A). Twenty four marginal tentacles are in two cycles: 12 en- 

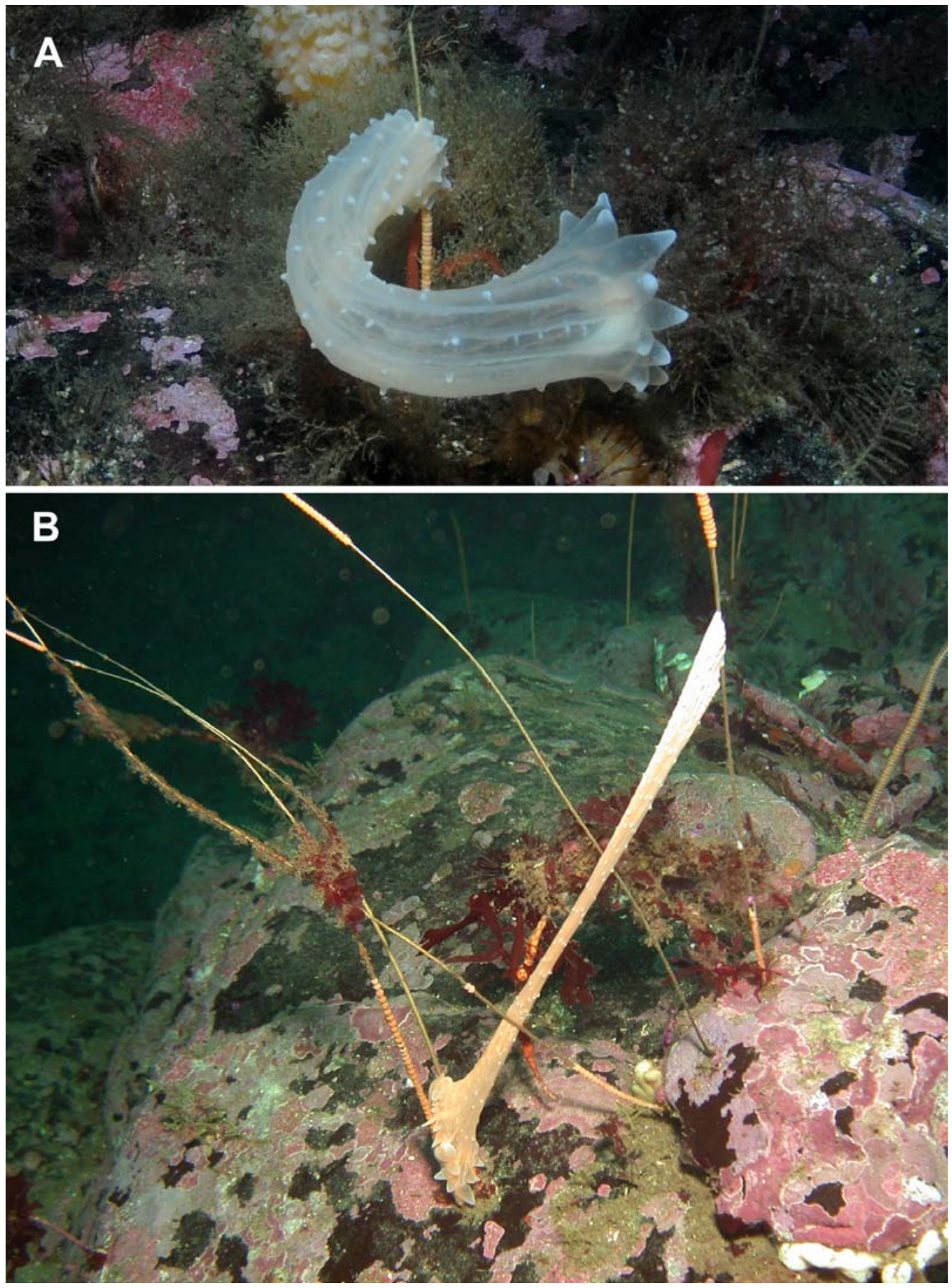

Fig. 24. Dactylanthus antarcticus (Clubb, 1908). A-B - living specimens on gorgonaceans.

Рис. 24. Dactylanthus antarcticus (Clubb, 1908). A-B - живые экземпляры на горгонариях. 

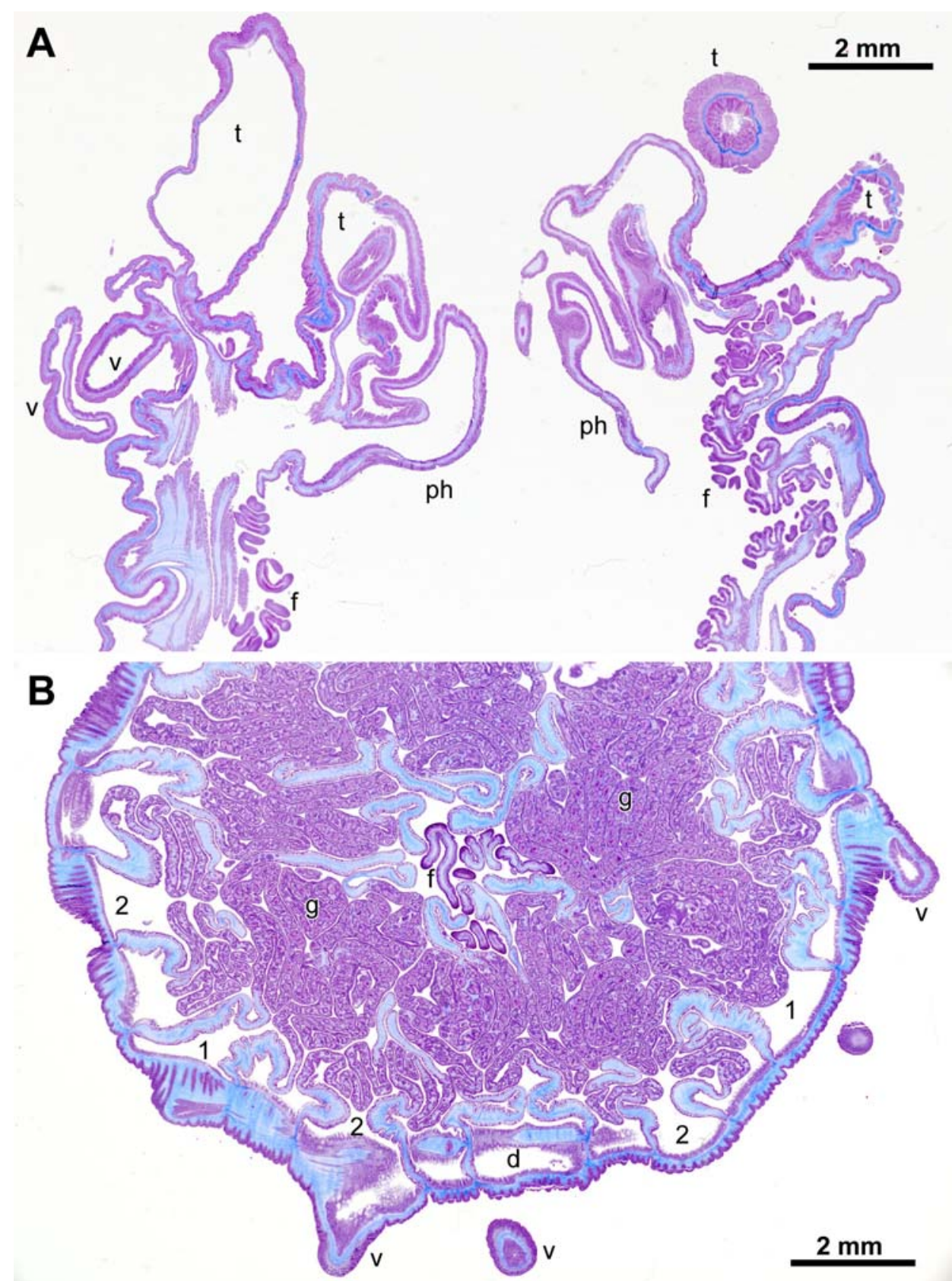

Fig. 25. Dactylanthus antarcticus (Clubb, 1908). A - longitudinal section through distal column; B transverse section through middle part of column.

Abbreviations: $\mathrm{d}$ - directives; $\mathrm{f}$ - filaments; $\mathrm{g}$ - gonads; $\mathrm{ph}$ - actinopharynx; $\mathrm{t}$ - tentacles; $\mathrm{v}$ - columnar vesicles; the numbers indicate the cycles of mesenterial pairs.

Рис. 25. Dactylanthus antarcticus (Clubb, 1908). А - продольный срез через дистальную часть колюмна; В - поперечный срез через среднюю часть колюмна.

Обозначения: d - направляющая пара мезентериев; f — филаменты; g — гонады; $\mathrm{ph}$ - актинофаринкс; $\mathrm{t}$ щупальца; v — колюмнарные везикулы; цифрами обозначены номера циклов пар мезентериев. 
Table 9. Size ranges (length $\times$ width, in microns) and distribution of cnidae of Dactylanthus antarcticus (measured in two specimens). Letters in brackets correspond to letters in Fig. 27.

Таблица 9. Размеры (длина $\times$ ширина, в микронах) и распределение стрекательных капсул Dactylanthus antarcticus (по двум экземплярам). Буквы в скобках соответствуют буквам на рис. 27.

\begin{tabular}{|l|c|c|}
\hline Body region & Cnidae & Size ranges $(\mu \mathrm{m})$ \\
\hline Base & basitrichs (rare) & $14-18 \times 2.5-3$ \\
\hline Column & (A) basitrichs (few) & $14-20 \times 2-4$ \\
\hline \multirow{3}{*}{ Columnar vesicles } & (B) spirocysts (few) & $16-24 \times 2-3$ \\
& (C) holotrichs (numerous) & $18-32 \times 2.5-4$ \\
\hline \multirow{3}{*}{ Marginal tentacles } & (D) basitrichs (rare) & $17-21 \times 2.5-3.5$ \\
\hline Oral disc & (E) spirocysts (few) & $16-24 \times 2-2.5$ \\
\hline \multirow{2}{*}{ Actinopharynx } & (F) holotrichs (numerous) & $22-29 \times 3-4$ \\
& $(\mathrm{G})$ basitrichs (few) & $12-21 \times 2.5-4$ \\
\hline Filaments & (H) basitrichs (common) & $14-20 \times 2.5-3.5$ \\
\hline Endoderm & (I) holotrichs (common) & $13-16 \times 3-4$ \\
\hline
\end{tabular}

docoelic and 12 exocoelic. The columnar vesicles are arranged in up to 24 longitudinal rows. The vesicles over the endocoels are usually more numerous and larger than those over the exocoels. In smaller specimens only endocoel vesicles may be developed. On expanded living specimens the columnar vesicles are significantly smaller than the marginal tentacles.

The longitudinal ectodermal muscles of column are weak. The circular endodermal muscles of column are well developed (Fig. 26D). The marginal sphincter is not present (Fig. 25A). The longitudinal muscles of the tentacles are ectodermal and weak (Fig. 26E). The mesenteries are arranged in two cycles, $6+6$ pairs (Fig. 25B). Only six pairs of the first cycle are perfect, two pairs of which are directives (Fig. 26A). Each mesentery in the middle part of column has two weak retractors, the main retractor (situated closer to the body wall) is better developed than the secondary retractor. The main and the secondary retractors are separated by the middle part of the mesentery containing gonads (Fig. 26B). In the distal part of the column, where the gonads not present, the main and the secondary retractors are fused together and form the single retractor muscle (Fig. 26C). The mesenteries of the first cycle have small round oral stomata
(Fig. 26A, arrow). The distal part of the mesenteries of the second cycle bear funnel shaped formations (termed "Rinnenförmige" by Carlgren, 1911) about $1 \mathrm{~mm}$ long (Fig. 26F). All filaments are unilobate.

All mesenteries are fertile. The sexes are separate. The eggs are up to $45 \mu \mathrm{m}$. The male follicles are up to about $300 \mu \mathrm{m}$. Spermatozoa are radially symmetrical, round headed, $2 \mu \mathrm{m}$ in diameter, with relatively large mitochondrial complex (Fig. 31Q).

Cnidom. Gracile spirocysts, holotrichs and basitrichs (see Fig. 27 and Table 9 for size ranges and distribution). All spirocysts have the same shape, they have thin walled, radially symmetrical capsule with wider anterior end, slightly and gradually narrowing toward the posterior end. The holotrichs have thick walled radially symmetrical capsule with the flap at the anterior end. The tubule forms a short loop at the anterior end of the capsule. The fired tubule is isodiametric, somewhat less than $1 \mu \mathrm{m}$ in diameter, small spines are arranged spirally along the length of the tubule with the equal distance between the coils (Fig. 26H). Most basitrichs have bilaterally symmetrical (somewhat curved) thick walled capsule with the flap at anterior end. The basal part of the tubule in unfired 
capsule is $4-10 \mu \mathrm{m}$. The fired tubule is very narrow (significantly less than $1 \mu \mathrm{m}$ in diameter), the spines at its basal part $(6-12 \mu \mathrm{m})$ are relatively long (about $1.5 \mu \mathrm{m}$ ) and form 2-4 spiral coils (Fig. 26 I). The holotrichs and the basitrichs (unlike the spirocysts) are stained by basic dyes.

Holotrichs are very numerous at the tips of the marginal tentacles and the tips of the columnar vesicles and form nematocyst batteries (Fig. $26 \mathrm{G})$. In these batteries the basitrichs are almost absent, however, they occur in the remaining parts of the marginal tentacles and columnar vesicles where holotrichs are not so numerous. On the base, on the column between the vesicles, on the oral disc and in the endoderm only basitrichs are present.

Remarks. This species was recorded and photographed (but not collected) at RAS in a depth of $42 \mathrm{~m}$. The species was seen only once in Fildes Bay, but was observed also at Napier Rock (Admiralty Bay, King George Island) some years before. Locally the species can be very abundant as observed in the Strait of Magellan by the third author. It is commonly found attached to gorgonaceans, which are their preferred food (Fig. 24B).
The capsules identified by previous authors as atrichs (Carlgren, 1940; Dunn, 1983; England, Robson, 1984) are holotrichs - their tubules bear spines (confirmed by examining of fired capsules). Rodríguez, López-González (2013) identified these capsules as holotrichs in the diagnosis, but as atrichs in the table listing size ranges of the cnida.

The basitrichs has not been reported for this species before. These capsules were reported as heterotrichs by England, Robson (1984: 324325) for this species. The basitrichs of Dactylanthus antarcticus are very similar with the basitrichs of Preactis millardae England, 1984 (see England, Robson, 1984, Fig. 4B: d). The capsules identified as atrichs in the original description of $P$. millardae are actually holotrichs - the spirally arranges spines are clearly seen on the tubule of the discharged capsule (see England, Robson, 1984, Fig. 4B: i). The holotrichs and the basitrichs in P. millardae have apical flaps, they are visible on the photos of discharged holotrichs and basitrichs (England, Robson, 1984, Fig. 4B: i, j). Thus the cnidom of these two species has the same set of nematocysts is more similar than was thought previously.

Fig. 26. Dactylanthus antarcticus (Clubb, 1908). A - transverse section on the level of actinopharynx, arrow indicates the oral stomata; B - transverse section of the mesentery of the second cycle in the middle part of column; $\mathrm{C}$ - transverse section of the mesentery of the second cycle in the distal part of column; $\mathrm{D}$ - transverse section through the wall of column showing endodermal circular muscles; E - transverse section through marginal tentacles showing weak ectodermal muscles; F - distal part of two mesenteries of the second cycle showing funnel shaped formations (arrows); $\mathrm{G}$ - transverse section through distal part of the columnar vesicle showing battery of nematocysts in the ectoderm; $\mathrm{H}$ - exploded holotrich from filament, arrow indicate the apical flaps; I - exploded basitrich from filament, arrow indicate the apical flaps.

Abbreviations: $\mathrm{d}$ - directives; ec — ectoderm; en — endoderm; $\mathrm{f}$ - filaments; $\mathrm{g}$ - gonads; od — oral disc; $\mathrm{ph}$ actinopharynx; $r$ - retractor; $r 1$ - main retractor; $r 2-$ secondary retractor; the numbers indicate the cycles of mesenterial pairs.

Рис. 26. Dactylanthus antarcticus (Clubb, 1908). А - поперечный срез через колюмн на уровне актинофаринкса, стрелка указывает на оральную стомату; В - поперечный срез через мезентерий второго цикла в средней части колюмна; $\mathrm{C}$ - поперечный срез через мезентерий второго цикла в дистальной части колюмна; D - поперечный срез через стенку колюмна, показывающий энтодермальные циркулярные мускулы; Е — поперечный срез через маргинальное щупальце показывающий слабые эктодермальные мускулы; F - дистальная часть двух мезентериев второго цикла, видны воронковидные формации (указаны стрелками); $\mathrm{G}$ - поперечный срез через дистальную часть везикулы колюмна, показывающий батарею нематоцист в эктодерме; Н - выстреливший голотрих из филамента, стрелка указывает на апикальный клапан; I - выстреливший базитрих из филамента, стрелка указывает на апикальный клапан.

Обозначения: $\mathrm{d}$ - направляющая пара мезентериев; ec - эктодерма; en - энтодерма; $\mathrm{f}$ - филаменты; $\mathrm{g}$ гонады; od - оральный диск; ph - актинофаринкс; r - ретрактор; r1 - основной ретрактор; r2 - вторичный ретрактор; цифрами обозначены номера циклов пар мезентериев. 


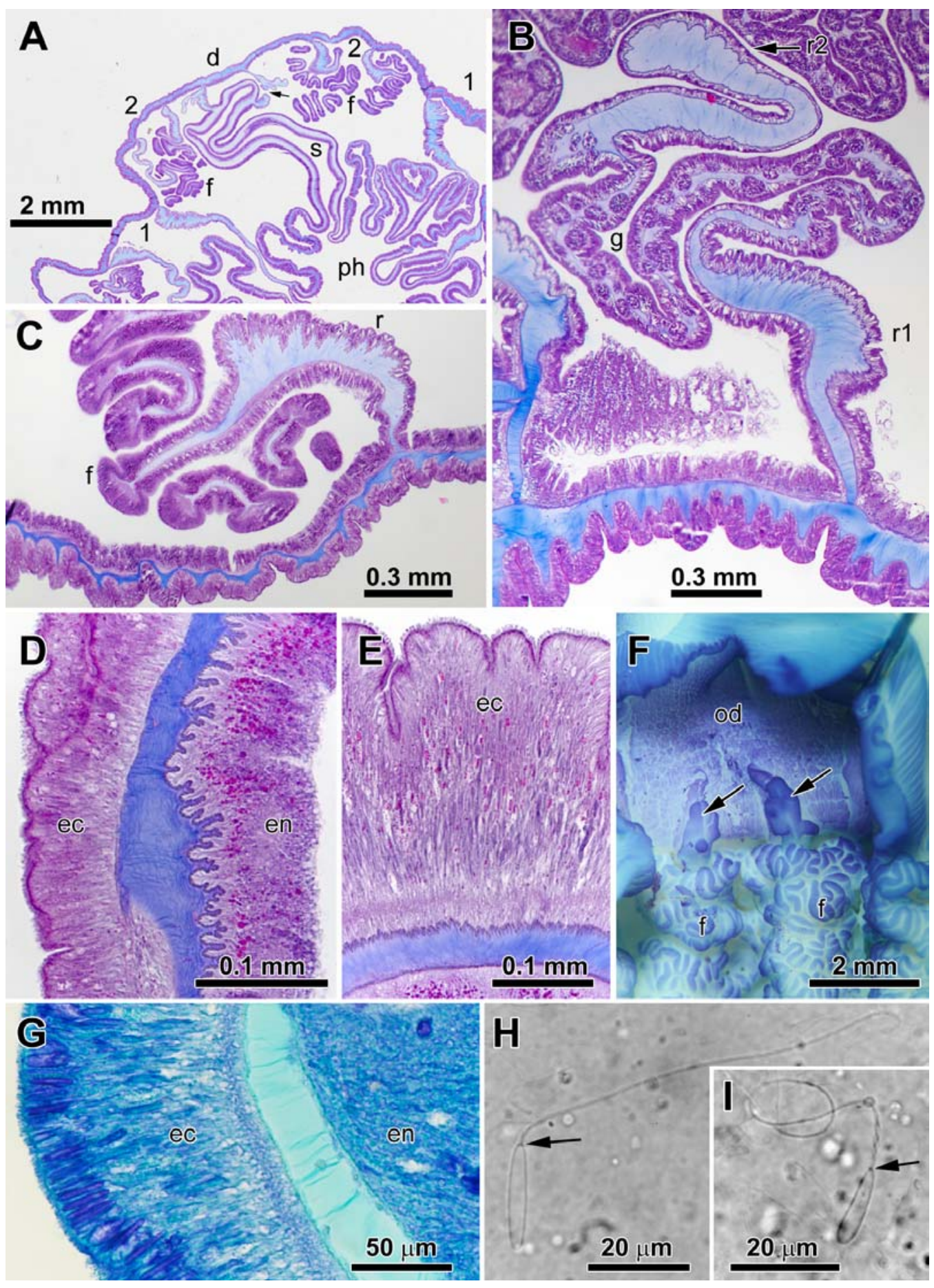




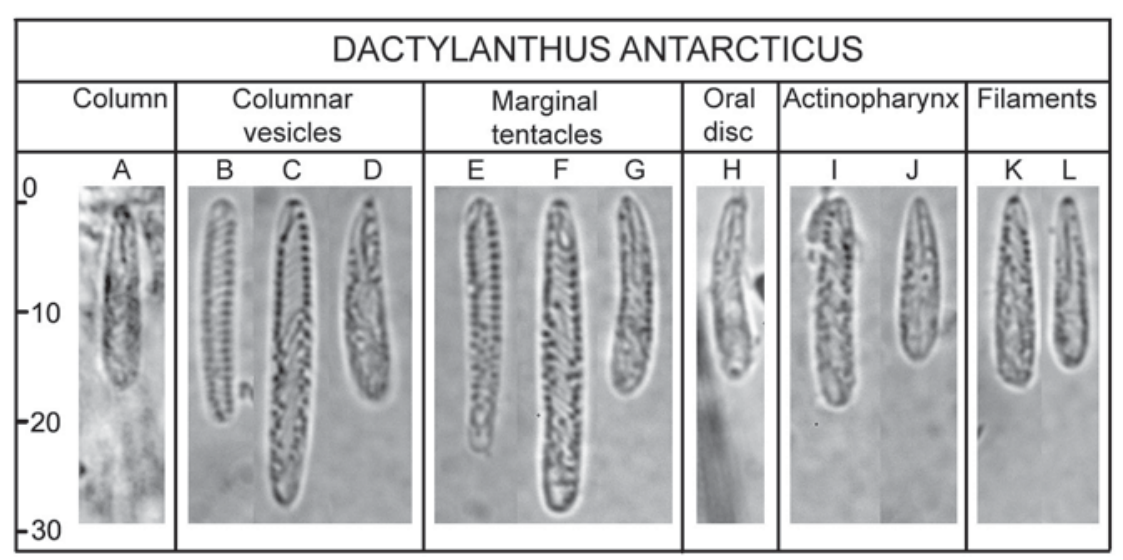

Fig. 27. Dactylanthus antarcticus (Clubb, 1908), cnidom (see Table 9 for size ranges).

Рис. 27. Dactylanthus antarcticus (Clubb, 1908), книдом (размеры указаны в табл. 9).

Carlgren(1911) described and figured funnel shaped formations at the tops of the mesenteries of the second cycle as structures composed of two rounded lobes. In the present specimens they have more irregular shape with additional lobes and conform more to the description given by England (in Dayton et al., 1997).

\section{Order Corallimorpharia}

Family Corallimorphidae Hertwig, 1882

\section{Corallimorphus karinae sp.n.} Table 10; Fig. 28-31P.

Corallimorphus profundus: Riemann-Zürneck, Iken, 2003: 368. (Not Moseley, 1877: 300).

Material examined. Holotype: ZIN 11336, RAS, 201102-15-(06), about $40 \mathrm{~m}$, one specimen (male).

Description. External anatomy. In preserved condition the specimen is $26 \mathrm{~mm}$ in diameter and $19 \mathrm{~mm}$ in height, very soft in touch (Fig. 28B). The column and the oral disc possess longitudinal furrows. The basal disc in collected specimen is torn off. In live the oral disc is circular, its diameter is greater than the diameter of column. The slit-like mouth is on the top of a very prominent, sharply defined oral cone which occupies a significant part of the oral disc, especially in preserved condition. In the preserved specimen the oral disc is contracted (folded, see Fig. 29H) and the upper part of the specimen is about of the same diameter as the middle of column. The marginal tentacles, about 76 in number, are long, up to $10 \mathrm{~mm}$ (in contract- ed condition), rather thick at base, gradually tapering toward the tips, with large acrospheres. Their stalks are smooth (not corrugated as in Sideractis) and rather stout in live, contracted and bent inward in preserved specimen where they hide the largest part of the oral disc. The tentacles are arranged decamerously in four cycles: $10+10+20+36$. There are no traces of discal tentacles (that is especially evident on the photo of expanded living specimen Fig. 28A).

The acrospheres in live are bright white, otherwise the specimen is not coloured, being rather transparent in live and opaque white in preservative (Fig. 28A-D).

Internal anatomy and histology. The mesogloea of the column is not especially thick, less than $1 \mathrm{~mm}$, gelatinous, looking quite homogenous on hand sections but the staining reveals peculiar lamellar structures (probably artefacts of contraction) and occasional small cells. Its endodermal surface is more or less even, while the outer surface has irregular longitudinal furrows (Fig. 29A). The thickness of columnar ectoderm and endoderm is about 200 $\mu \mathrm{m}$. Longitudinal ectodermal muscles of column are weak but well discernible (Fig. 29G), better developed in distal part of column. The circular endodermal columnar muscles are stronger than ectodermal muscles. The mesogloea of the oral disc has deep radial furrows over endoand exocoels. Furrows over the endocoels are wider and deeper than those over the exocoels (Fig. 29B). Radial ectodermal muscles of oral disc are well developed (Fig. 29E). The stalks of 

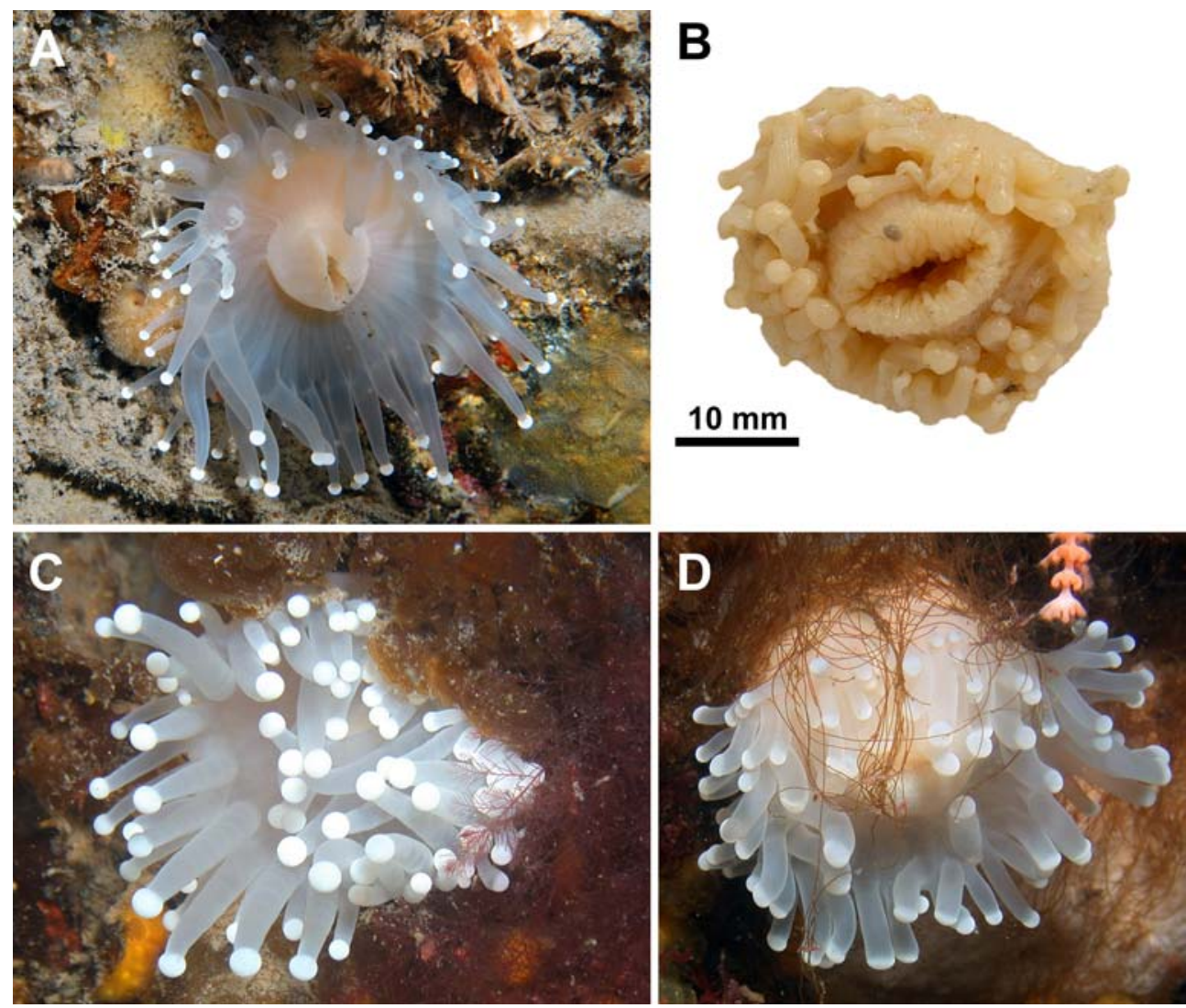

Fig. 28. Corallimorphus karinae sp.n. A - holotype in natural environment; B - holotype, formalin preserved, top view; C-D - living specimens photographed (but not collected) at Napier Rock (Admiralty Bay, King George Island) in 2002.

Рис. 28. Corallimorphus karinae sp.n. А - голотип в естественной среде обитания; В - голотип, фиксированный, вид сверху; C-D - живые экземпляры, сфотографированные (но не собранные) в районе Napier Rock (Admiralty Вay, остров Короля Георга) в 2002.

the tentacles are longitudinally furrowed (Fig. 29F) and provided by well developed longitudinal ectodermal and circular endodermal muscles; the muscles are not present in acrospheres. The thickness of ectoderm in tentacle stalks is up to $150 \mu \mathrm{m}$, those of acrospheres is much thicker, $350-400 \mu \mathrm{m}$. The endoderm of tentacles is about $100 \mu \mathrm{m}$, those of acrospheres lacks vacuolated cells and differs from the endoderm of tentacle stalks. The actinopharynx is rather long, without histologically differentiated siphonoglyphs. It has 36 very prominent longitudinal ridges which more or less correspond to insertions of perfect mesenteries with the exception of directive mesenteries - the ridges corresponding to directive mesenteries are either poorly developed or indiscernible (Fig. 29A).
The mesenteries are arranged decamerously in three cycles with several additional pairs of fourth cycle (Fig. 29D). Mesenteries of two first cycles are perfect $(10+10$ pairs $)$, so the total number of perfect mesenteries is 40 . Perfect mesenteries in their distal parts (i.e. closer to oral disc) have well developed retractors with thick and long, sometimes branched, mesogloeal processes (Fig. 29A, B). Inner (closer to actinopharynx) part of each perfect mesentery has much thickened mesogloea, which rapidly narrows to a thin membrane where the mesentery is attached to actinopharynx. In proximal parts of perfect mesenteries retractors are poorly developed (Fig. 29C). Only perfect mesenteries are fertile and have filaments. Mesenteries of third and few pairs of fourth cycle are small, lack 
filaments, gonads and retractors and may be considered as microcnemes. The examined specimen was male, male follicles are up to about 250 $\mu \mathrm{m}$. Spermatozoa radially symmetrical, round headed, 3-4 $\mu \mathrm{m}$ in diameter (Fig. 31P).

Cnidom. Gracile spirocysts, holotrichs, bmastigophores, p-mastigophores D, p-mastigophores E (see Fig. 30 and Table 10 for size ranges and distribution). Ectoderm of the oral disc contains the same p-mastigophores D as column. Small b-mastigophores are common in the endoderm of all parts of the specimen (in column, tentacles, oral disc, pharynx and mesenteries). In filaments these small b-mastigophores are present only in the digestive region but not in the cnidoglandular tract. In actinopharynx p-mastigophores E and small b-mastigophores are present only in its most lower portion, while the upper half of actinopharynx contains only holotrichs. Spirocysts in the stalks of the tentacles present only near the acrospheres. Small b-mastigophores, of the same type as those of endoderm, were occasionally seen in histological sections in the ectoderm of column, oral disc and stalks of the tentacles, but we failed to find them on squash preparations.

Etymology. The species is named after Karin Riemann-Zürneck, a prominent authority in taxonomy of sea anemones who, together with Katrin Iken, was first who examined this species.

Remarks. This rare species was collected at RAS in a depth of about $40 \mathrm{~m}$ on a vertical rock. The divers searched for the species during sev- eral dives at RAS, but were not able to find a second specimen. However, the third author recorded and photographed (but not collected) two specimens of this species also at Napier Rock (Admiralty Bay, King George Island, $62^{\circ}$ $10^{\prime} \mathrm{S} 58^{\circ} 26^{\prime} \mathrm{W}$ ) at depth $30-40 \mathrm{~m}$ in 2002 (Figs. $28 \mathrm{C}, \mathrm{D})$. One of these specimens had about 70 marginal tentacles and another about 80 , and both had no discal tentacles.

The most interesting feature of the present species is the absence of discal tentacles, a character known among Corallimorpharia only in two monotypic genera, Sideractis Danielssen, 1890 and Nectactis Gravier, 1918 (see Hartog et al., 1993). However it cannot be assigned to either of these genera: Nectactis singularis Gravier, 1918 is a very different, tiny, disc-shaped species having little in common with the present species (see RiemannZürneck, 1979 and Hartog et al., 1993), and Sideractis glacialis Danielssen, 1890, with its corrugate tentacle stems due to the presence of batteries of cnidae does not appear to be closely related. Further, the cnidom of the present species is not compatible with the cnidom of Sideractis or Nectactis but agrees with the cnidom of Corallimorphus. In particular it has peculiar lanceolate b-mastigophores in the acrospheres (Fig. 30F) which are considered to be specific for Corallimorphus (see Riemann-Zürneck, Iken, 2003) and we assign the present species to this genus.

Thirteen specimens of Corallimorpharia described and identified by Riemann-Zürneck,

Fig. 29. Corallimorphus karinae sp.n., histological sections. A — transverse section through middle part of column; B - transverse section of distal part of the body through oral disc and actinopharynx; C transverse section through proximal part of column, note the presence of gonads on the mesenteries on the first cycle; D - transverse section of column showing small mesenteries of the fourth cycle; E - radial ectodermal muscles of oral disc; F - transverse section through the tentacle; $\mathrm{G}$ - transverse section of column showing longitudinal ectodermal columnar muscles; $\mathrm{H}$ - longitudinal section of the body.

Abbreviations: a - acrosphera; $\mathrm{c}$ - column; $\mathrm{d}$ - directives; $\mathrm{f}$ - filaments; $\mathrm{g}$ - gonads; od — oral disc; $\mathrm{ph}$ actinopharynx; $\mathrm{r}$ - retractors; $\mathrm{t}$ - tentacle; the numbers indicate the cycles of mesenterial pairs.

Рис. 29. Corallimorphus karinae sp.n., гистологические срезы. А - поперечный срез через середину колюмна; В - поперечный срез дистальной части тела через оральный диск и актинофаринкс; $\mathrm{C}-$ поперечный срез через проксимальную часть колюмна, видно наличие гонад на мезентериях первого цикла; D — поперечный срез через колюмн, показывающий маленькие мезентерии четвертого цикла; E - радиальные эктодермальные мускулы орального диска; F — поперечный срез щупальца; G поперечный срез через стенку колюмна, показывающий эктодермальные мускулы колюмна (указаны стрелками); Н — продольный срез тела.

Обозначения: a - акросфера; с — колюмн; d — направляющие мезентерии; f — филаменты; g — гонады; od — оральный диск; ph - актинофаринкс; r - ретракторы; $\mathrm{t}$ - щупальце; цифрами обозначены номера циклов пар мезентериев. 


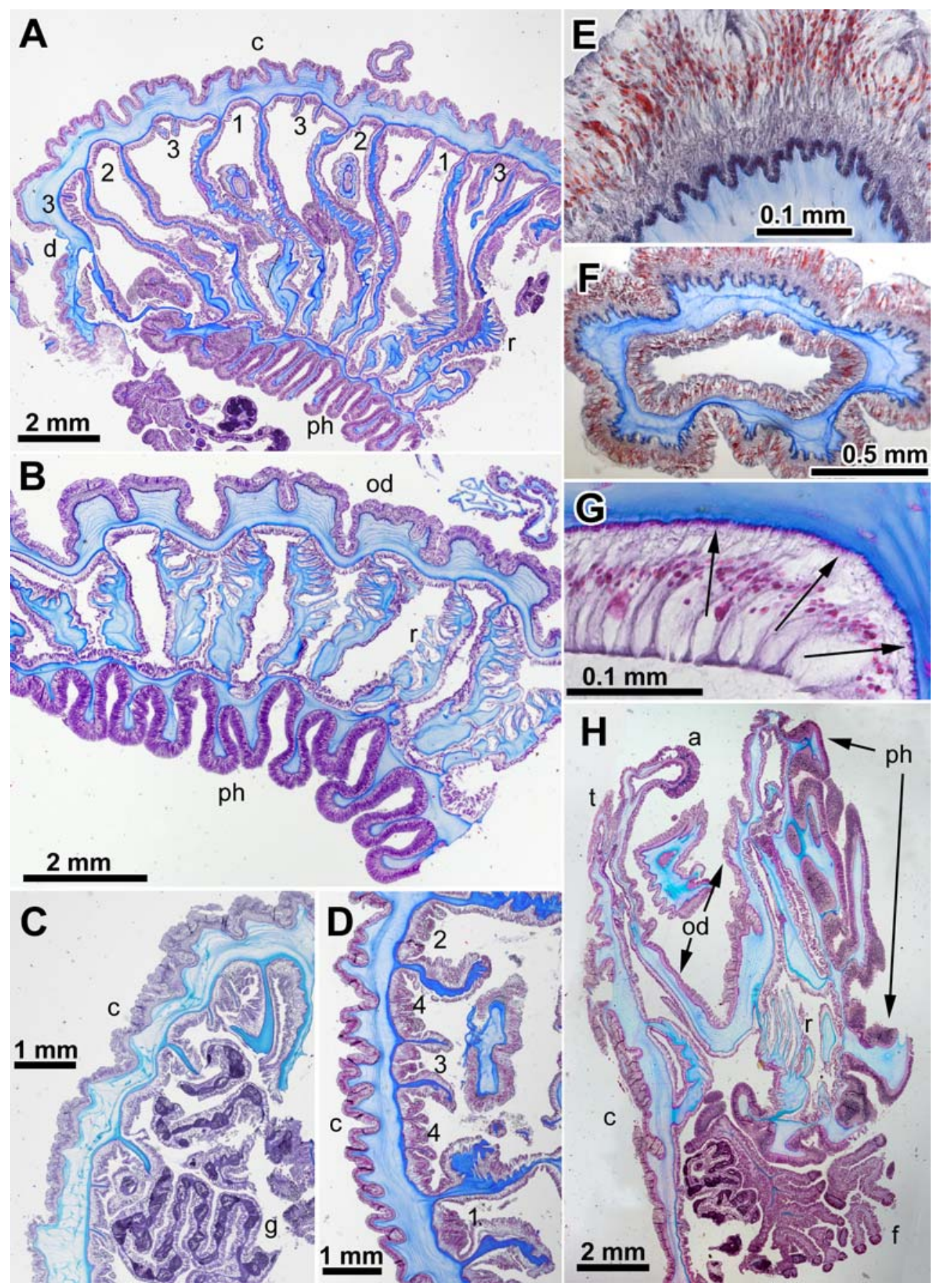


Table 10. Size ranges (length $\times$ width, in microns) and distribution of cnidae of Corallimorphus karinae sp.n. (measured in one specimen). Letters in brackets correspond to letters in Fig. 30.

Таблица 10. Размеры (длина $\times$ ширина, в микронах) и распределение стрекательных капсул Corallimorphus karinae sp.n. (по единственному экземпляру). Буквы в скобках соответствуют

буквам на рис. 30 .

\begin{tabular}{|l|c|c|}
\hline Body region & Cnidae & Size ranges $(\mu \mathrm{m})$ \\
\hline Column & (A) p-mastigophores D (common) & $23-47 \times 6.5-11.5$ \\
\hline \multirow{3}{*}{ Acrospheres } & (B) spirocysts (numerous) & $42-88 \times 3-5$ \\
& (C) p-mastigophores E (numerous) & $183-250 \times 15-20$ \\
& (D) p-mastigophores D (very numerous) & $(118) 130-194 \times 6-9$ \\
& (E) b-mastigophores (few) & $85-100 \times 5-6$ \\
& (F) b-mastigophores (common) & $64-89 \times 3-4$ \\
Tentacle stalks & (G) b-mastigophores (rare) & $27-43 \times 4-6$ \\
\hline \multirow{3}{*}{ Actinopharynx } & (H) spirocysts (very rare) & $37-52 \times 4-5$ \\
& (I) p-mastigophores D (common) & $26-85 \times 6.5-11$ \\
\hline Cnidoglandular & (J) holotrichs (numerous) & $40-78 \times 7.5-12$ \\
tracts & (K) p-mastigophores E (few) & $102-140 \times 17-22$ \\
\hline Endoderm & (M) p-mastigophores E (common) & $13-21 \times 5-6$ \\
\hline
\end{tabular}

Iken(2003) as Corallimorphus profundus Moseley, 1877 are certainly conspecific with the present specimen. These specimens were also collected by divers at about $40 \mathrm{~m}$ depth. Most of them had only marginal tentacles and only five had very few (one to four) tiny discal. The photo of the living specimen (Riemann-Zürneck, Iken, 2003, Fig. 1) appears to show a specimen without discal tentacles resembling closely the present specimen. The nematocyst data reported Riemann-Zürneck, Iken (2003) are in a good agreement with our data. However, we found pmastigophores $\mathrm{E}$ and b-mastigophores only in the most lower portion of the actinopharynx, while the holotrichs reported by Riemann-Zürneck, Iken (2003) are numerous in most parts of the actinopharynx. Further, in addition to slender lanceolate b-mastigophore (Fig. 30F) reported by Riemann-Zürneck, Iken (2003) in acrospheres we found rather rare, somewhat longer, thicker b-mastigophore with rounded distal end and with shorter shaft (17-22 $\mu \mathrm{m}$ in unfired capsule vs. $24-30 \mu \mathrm{m}$ in the usual lanceolate b-mastigophore) (Fig. 30E). These bmastigophores are very similar but belong to two different types. Two capsules of small b- mastigophores reported by Riemann-Zürneck, Iken (2003) in acrospheres belong to two different types, the smaller of which $(12 \times 4 \mu \mathrm{m})$ occurs (and is common) in endoderm. All nematocysts which Riemann-Zürneck, Iken (2003) identified as basitrichs are actually b-mastigophores, unlike the typical basitrichs they do not stain by basic dyes and do not have apical flaps. Nematocysts which Riemann-Zürneck, Iken (2003) identify as holotrichs belong to two different types. In the present paper we follow Hartog et al. (1993) and identify them as holotrichs in actinopharynx and p-mastigophores $\mathrm{E}$ in acrospheres and filaments.

Although Riemann-Zürneck, Iken (2003: 379) ascribed their specimens to Corallimorphus profundus they suggested that these specimens may be genetically separated from deepwater populations. Indeed, most deep-water specimens identified as C. profundus have 1020 discal tentacles. Four discal tentacles (all on one side) reported by Fautin (1984: 4) in one specimen (among 27 examined) should be considered as anomaly (as it was correctly pointed by Fautin, 1984: 8). On the other hand in the herein discussed shallow-water population of 


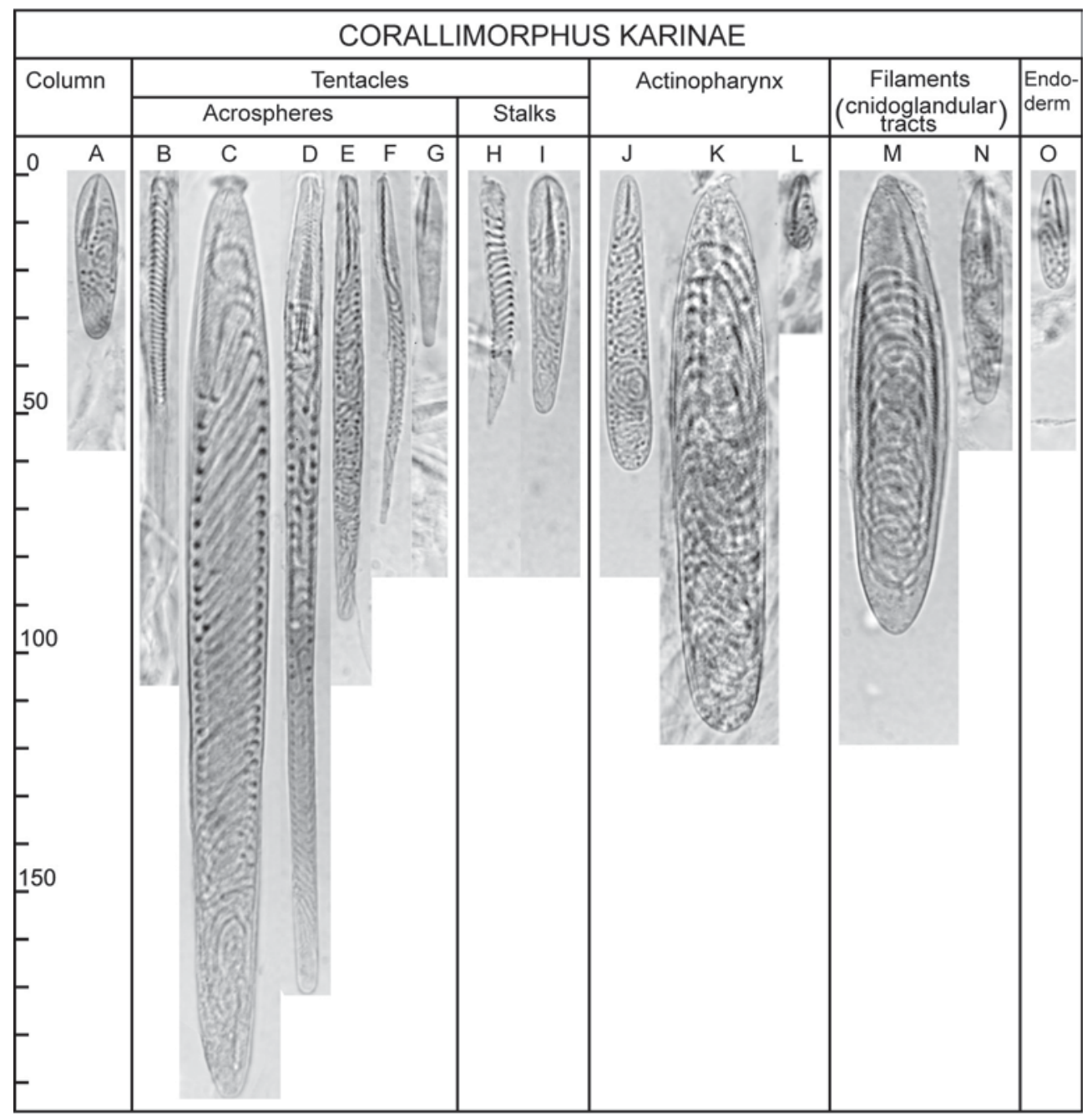

Fig. 30. Corallimorphus karinae sp.n., cnidom (see Table 10 for size ranges).

Рис. 30. Corallimorphus karinae sp.n., книдом (размеры указаны в табл. 10).

Corallimorphus the total absence of discal tentacles is a normal condition and the presence of as much as four discals in one specimen is an exception. Thus, we have no doubt that the present specimen, as well as the specimens described by Riemann-Zürneck, Iken (2003), are not conspecific with $C$. profundus.

Comparison of these specimens with the original description and the type specimens of C. profundus reveals even more profound differences. The original description (Moseley, 1877) is based on one specimen dredged in the South Pacific in $39^{\circ} 4^{\prime} \mathrm{S}, 105^{\circ} 5^{\prime} \mathrm{W}, 2025$ fathoms $(3686 \mathrm{~m})$. In the end of his description
Moseley (1877: 301) briefly noted another "closely similar" specimen from $33^{\circ} 42^{\prime} \mathrm{S}$, $78^{\circ} 18^{\prime} \mathrm{W}, 1375$ fathoms $(2503 \mathrm{~m})$. These two specimens are listed as syntypes by Fautin (2014). Both are larger than the present specimen, but marginal tentacles are less numerous, 48 and 52 (in larger, $7.5 \mathrm{~cm}$ specimen) and the number of discal tentacles is 12. Marginal tentacles in both syntypes are very short and thin, so the whole oral disc, including margin, is exposed (see photographs of syntypes provided by Fautin, 2014), while in C. karinae sp.n. the long and thick tentacles hide the most part of the oral disc in preserved specimens (Fig. 28B; Rie- 


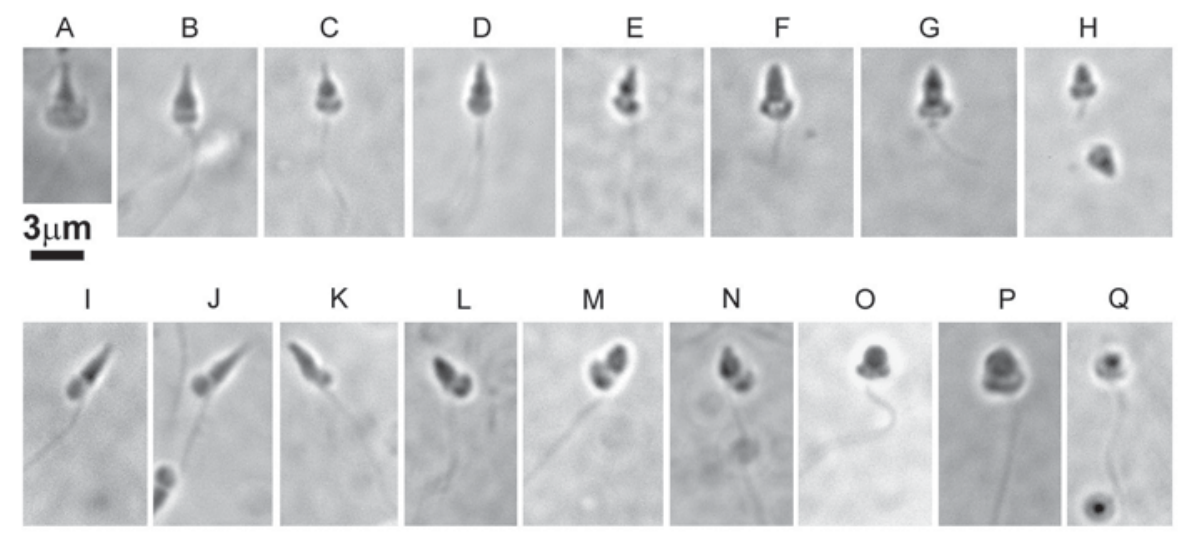

Fig. 31. Spermatozoa of several species of sea anemones. A - Edwardsia inachi; B - Hormosoma scotti; $\mathrm{C}$ - Artemidactis victrix; D - Neohalcampa sheikoi; E - Eltaninactis psammophora; F - Eltaninactis infundibulum; $\mathrm{G}$ - Halcampoides sp.; $\mathrm{H}$ - Hormathia lacunifera $; \mathrm{I}$-Isoparactis fabiani; $\mathrm{J}$ - Isoparactis fionae; $\mathrm{K}$ - Paraisanthus tamarae; L - Armactinia antarctica; M - Glyphoperidium bursa; N Urticina eques; O - Peachia quinquecapitata; P - Corallimorphus karinae; Q - Dactylanthus antarcticus.

Рис. 31. Сперматозоиды некоторых видов морских анемон. А - Edwardsia inachi; В - Hormosoma scotti; C - Artemidactis victrix; D - Neohalcampa sheikoi; E - Eltaninactis psammophora; F Eltaninactis infundibulum; G - Halcampoides sp.; H - Hormathia lacunifera; I — Isoparactis fabiani; $\mathrm{J}$ - Isoparactis fionae; $\mathrm{K}$ - Paraisanthus tamarae; L - Armactinia antarctica; $\mathrm{M}$ - Glyphoperidium bursa; N - Urticina eques; O - Peachia quinquecapitata; P - Corallimorphus karinae; Q Dactylanthus antarcticus.

mann-Zürneck, Iken, 2003, Fig. 2). Figures of a trawled but still living specimen provided by Moseley (1877, Fig.7 and 8) are informative and show a species quite different from living specimens of $C$. karinae sp.n. According to Moseley (1877: 300) the body of C. profundus is "firm and rigid", a condition different from those of C. karinae sp.n. Moseley's specimen is regularly hexamerous with 12 pairs of perfect mesenteries (Moseley, 1877, Fig. 7), while $C$. karinae sp.n. is decamerous with 20 pairs of perfect mesenteries. In general $C$. profundus appears to be more closely related to $C$. rigidus Moseley, 1877 than to $C$. karinae sp.n.

Antarctic specimens identified by Rodríguez, López-González (2013) as C. profundus resemble $C$. karinae sp.n. externally: the tentacles are long, have thick stems and tend to hide oral disc in preserved specimens. In our opinion these specimens cannot be assigned to C. profundus. They differ quite clearly from the type specimens of $C$. profundus (see above) and probably should be better assigned to $C$. antarcticus Carlgren et Stephenson, 1929 (which we consider as a valid species, not identical with
C. profundus, in particular it has much longer and thicker tentacles which length may be longer than the radius of the oral disc, see Carlgren, Stephenson, 1929, while in C. profundus the tentacles are several times shorter than the radius of the oral disc, see above). These specimens differ from $C$. karinae sp.n. by possession of 12-21 discal tentacles. There are also some differences in cnidom. In particular, small bmastigophores, which are present in ectoderm of acrospheres in C. karinae sp.n. not reported in specimens described by Rodríguez, LópezGonzález (2013), however, these small and not numerous nematocysts may be easily overlooked among crowded larger cnidae of other types. In mesenterial filaments Rodríguez, López-González (2013) found structures which they identified as "agarocysts" (originally spelled as "agaricysts" by Pires, 1997). They are not present in C. karinae sp.n. Further, according to Rodríguez, López-González (2013) their specimens have only one cycle of perfect mesenteries (six pairs?). This feature (if correctly reported) would distinguish their specimens from all Corallimorhus species for which the number of cycles perfect 
mesenteries is known: C. profundus, C. rigidus, C. denhartogi Fautin, White et Pearson, 2002 and C. pilatus Fautin, White et Pearson, 2002 have 12 pairs of perfect mesenteries (two cycles) and C. karinae sp.n. has 20 pairs (also two cycles) (Moseley, 1877; Fautin et al., 2002).

Type specimen of $C$. antarcticus has 17 discal tentacles (see Carlgren, Stephenson, 1929), the specimen of $C$. antarcticus reported by Grebelnyi (1975) has 16 discal tentacles.

Riemann-Zürneck, Iken (2003: 372 and 380, Fig. 4) discuss the presence of "villous gastroderm presumably releasing vesicles $3-8 \mu \mathrm{m}$ in diameter into the gastrocoel" and suggest their "role in the support of brooded developmental stages". We found similar structures in the present specimen which is male and has no brooded stages.

Currently Corallimorphus karinae n.sp, is known only from shallow depths from King George Island (the present record) and from Palmer Station, Antarctic Peninsula (RiemannZürneck, Iken, 2003). The only other record of the genus on diver accessible depths is a record of C. antarcticus from 30-42 $\mathrm{m}$ from Davis Sea, i.e. from the opposite side of Antarctica reported by Grebelnyi (1975).

\section{Acknowledgments}

We are grateful to the Scientific Diving Groups of the Universidad Austral de Chile and the University of Rostock, Germany, for participation and assistance in the field expeditions. We also grateful to Dr. E. Rodríguez for loaning the specimens of Eltaninactis infundibulum, to the University Museum of Bergen and to Dr. J. Kongsrud for loaning type specimens of Cactosoma abyssorum and Phellia crassa and Dr. N. Budanova who helped to receive these specimens. Dr. M. Daly and Dr. E. Rodríguez provide useful comments on the first version of this manuscript. We are grateful to three anonymous reviewers for valuable comments and corrections. Dr. A. Martynov identified gastropod shell to which Isosicyonis alba was attached.

This work was financed by the Chilean Antarctic Institute, INACh (project \#T-21-09).

\section{References}

Andres A. 1883. Le attinie. Contenente Bibliografia, Introduzione e Specigrafia. Leipzig: Verlag von Wilhelm Engelmann. 459 p.
Bozhenova O.V. 1988. [Current views on the classification of the nematocysts of Cnidaria] // O.A. Scarlato (ed.). [Porifera and Cnidaria. Modern and perspective investigations.] Leningrad: Zoological Institute. P.5771 [in Russian].

Cappola V.A., Fautin D.G. 2000. All three species of Ptychodactiaria belong to order Actiniaria (Cnidaria: Anthozoa) // Journal of the Marine Biological Association of the United Kingdom. Vol.80. P.995-1005.

Carlgren O. 1899. Zoantharien // Ergebnisse der Hamburger Magalhaensische Sammelreise. Bd.4. Hf.1. S.1-48.

Carlgren O. 1902. Actiniaria der Olga-Expedition // Wissenschaftliche Meeresuntersuchungen, Kommission zur wissenschaftlichen Untersuchung der deutschen Meere in Kiel, Biologischen Anstalt auf Helgoland. Bd.5. Hf.1. S.33-57.

Carlgren O. 1911. Über Dactylanthus (Cystiactis) antarcticus (Clubb) zugleich ein Beitrag zur Phylogenie der Actiniarien // Wissenschaftliche Ergebnisse der Schwedischen Südpolarexpedition, 1901-1903. Bd.6. Nr.5. S.1-31.

Carlgren O. 1921. Actiniaria. Part $1 / /$ The Danish IngolfExpedition. Vol.5. No.1. P.1-241.

Carlgren O. 1924. Actiniaria from New Zealand and its Subantarctic Islands // Papers from Dr. Th. Mortensen's Expedition 1914-16. Videnskabelige Meddelelser fra dansk naturhistoric Forenig. Vol.77. P.179-261.

Carlgren O. 1927. Actiniaria and Zoantharia // Further Zoological Results of the Swedish Antarctic Expedition 1901-1903. Vol.2. No.3. P.1-102.

Carlgren O. 1928. Actiniaria der Deutschen Tiefsee-Expedition // Wissenschaftliche Ergebnisse der Deutschen Tiefsee-Expedition. Bd.22. Hf.4. S.123-266.

Carlgren O. 1931. Zur Kenntnis der Actiniaria Abasilaria // Arkiv för zoologi. Bd.23A. Hf.3. S.1-47.

Carlgren O. 1939. Actiniaria and Zoantharia of the Scottish National Antarctic Expedition 1902-1904// Transactions of the Royal Society of Edinburgh. Vol.49. No.3. P.791-803.

Carlgren O. 1940. A contribution to the knowledge of the structure and distribution of the cnidae in the Anthozoa // Lunds Universitets Arsskrift. N.F. Adv.2. Bd.36. Nr.3. S.1-62.

Carlgren O. 1945. Further contributions to the knowledge of the cnidom in the Anthozoa especially in the Actiniaria // Lunds Universitets Arsskrift. N.F. Adv.2. Bd.41. Nr.9. S.1-24.

Carlgren O. 1949. A survey of the Ptychodactiaria, Corallimorpharia and Actiniaria // Kungliga Svenska Vetenskapsakadamiens Handlingar. Vol.1. P.1-121.

Carlgren O. 1959. Corallimorpharia and Actiniaria with description of a new genus and species from Peru // Reports of the Lund University Chile Expedition 1848-49, 38. Lunds Universitets Arsskrift. N.F. Adv.2. Vol.56. No.6. P.1-39.

Carlgren O., Stephenson T.A. 1929. Actiniaria // E.A. Briggs (ed.). Australasian Antarctic Expedition 191114 under the leadership of Sir Douglas Mawson, O.B.E., D.Sc., B.E., F.R.S. Scientific Reports. Series C.-Zoology and Botany. Sidney: Government Printer. Vol.9. No.2. P.5-34. 
Clubb J.A. 1908. Coelenterata. 4. Actiniae // National Antarctic Expedition 1901-1904. Natural History. Zoology. Vol.4. P.1-12.

Danielssen D.C. 1890. Actinida // The Norwegian NorthAtlantic expedition 1876-1878. Zoology. Vol.19. P.1-184.

Dayton P.K., England K.W., Robson E.A. 1997. An unusual sea anemone, Dactylanthus antarcticus (Clubb, 1908) (Order Ptychodactiaria), on gorgonarians in Chilean fjords // Proceedings of the 6th International Conference on Coelenterate Biology. 1995. P.135142.

Dunn D.F. 1983. Some Antarctic and sub-antarctic sea anemones (Coelenterata: Ptychodactiaria and Actiniaria) // Biology of the Antarctic Seas 14. Antarctic Research Series. Vol.39. P.1-67.

England K.W. 1987. Certain Actiniaria (Cnidaria, Anthozoa) from the Red Sea and tropical Indo-Pacific Ocean // Bulletin of the British Museum (Natural History) (Zoology). Vol.53. No.4. P.205-292.

England K.W. 1991. Nematocysts of sea anemones (Actiniaria, Ceriantharia and Corallimorpharia: Cnidaria): nomenclature // Hydrobiologia. Vol.216/217. P.691-697.

England K.W., Robson E.A., 1984. A new sea anemone from South Africa (Anthozoa, Ptychodactiaria) // Annals of the South African Museum. Vol.94. Pt.5. P.305-329.

Farquhar H. 1898. Preliminary account of some NewZealand Actiniaria // Journal of Linnean Society. Zoology. Vol.26. P.527-536.

Fautin D.G. 1984. More Antarctic and Subantarctic sea anemones (Coelenterata: Corallimorpharia and Actiniaria) // Biology of the Antarctic Seas 16. Antarctic Research Series. Vol.41. P.1-42.

Fautin D.G. 2014. Hexacorallians of the World. Available from: http://geoportal.kgs.ku.edu/hexacoral/anemone2/index.cfm

Fautin D.G., White T.R., Pearson E. 2002. Two new species of deep-water Corallimorpharia (Cnidaria: Anthozoa) from the Northeast Pacific, Corallimorphus denhartogi and C. pilatus // Pacific Science. Vol.56. No.2. P.113-124.

Grebelnyi S.D. 1975. [On the fauna of Actiniaria and Corallimorpharia of the Eastern Antarctic coastal waters] // Biologia Morya. Vol.5. P.3-14 [in Russian].

Hand C. 1954. The sea anemones of Central California, part 1. The Corallimorpharian and Athenarian anemones // Wasmann Journal of Biology. Vol.12. P.345-375.

Hartog J.C. den. 1977. Notes on the little known sea anemone Cataphellia brodricii and on the closely allied Hormathia coronata and Paraphellia expansa (Actiniaria, Hormathiidae) // Netherlands Journal of Zoology. Vol.27. No.3. S.237-244.

Hartog J.C. den, Ocaña O., Brito A. 1993. Corallimorpharia collected during the CANCAP expeditions (1976-1986) in the south-eastern part of the North Atlantic // Zoologische Verhandelingen Leiden. Vol.282. P.1-76.

Lauretta D., Haussermann V., Brugler M.R., Rodriguez E. 2013. Isoparactis fionae sp. nov. (Cnidaria: Anthozoa: Actiniaria) from Southern Patagonia with a discussion of the family Isanthidae // Organisms Diversity \& Evolution, DOI 10.1007/s13127-013-0149-z
Manuel R.L. 1988. British Anthozoa // Synopses of the British Fauna (N.S.). London: Academic Press. No.18. $241 \mathrm{p}$.

Mariscal R.N. 1974. Nematocysts // L. Muscatine, H.M. Lenoff (eds.). Coelenterate Biology. New York: Academic Press. P.129-178.

McMurrich J.P. 1893. Report on the Actiniae collected by the United States Fish Commission Steamer Albatross during the winter of 1887-1888// Proceedings of the United States National Museum. Vol.16. P.119-216.

McMurrich J.P. 1904. The Actiniae of the Plate Collection // Zoologische Jahrbücher. Vol.6. No.2. P.215-306.

Moseley A.N. 1877. On new forms of Actiniaria dredged in the Deep-Sea; with a description of certain pelagic surface-swimming species // Transactions of Linnean Society. Ser.2. Zoology. Vol.1. P.295-306.

Östman C., Kultima J.R. Roat C., Rundblom K. 2010. Acontia and mesentery nematocysts of the sea anemone Metridium senile (Linnaeus, 1761) (Cnidaria: Anthozoa) // Scientia Marina. Vol.74. No.3. P.483-497.

Pax F. 1922. Diagnosen neuer Actiniarien aus der Ausbeute der Deutschen (1901-1903) und der Französischen (1908-1910) Südpolar-Expedition // Zoologisher Anzeiger. Bd.54. S.74-92.

Pires D.O. 1997. Cnidae of Scleractinia // Proceedings of the Biological Society of Washington. Vol.110. P.167-185.

Riemann-Zürneck K. 1978. Tiefsee-Actinien der Familie Actinoscyphiidae aus dem Nordatlantik (Actiniaria, Mesomyaria) // Zoologica Scripta Bd.7. S.145-153.

Riemann-Zürneck K. 1979. Two disc-shaped deep-sea Anthozoa from the Gulf of Biscay, with a survey of adaptation types in the Actiniaria // Zoomorphologie. Vol.93. P.227-243.

Riemann-Zürneck K. 1980. Actiniaria des Sudwestatlantik. 5. Bolocera, Isotealia, Isosicyonis (Actiniidae) // Mitteilungen aus dem Naturhistorischen Museum in Hamburg. Bd.77. S.19-33.

Riemann-Zürneck K. 1991. The abyssal sea anemone Kadosactis sulcata Carlgren 1934 (Cnidaria, Actiniaria: Kadosactidae nov. fam.) // Senckenbergiana maritima. Vol.21. P.191-204.

Riemann-Zürneck K., Iken K. 2003. Corallimorphus profundus in shallow Antarctic habitats: Bionomics, histology, and systematics (Cnidaria: Hexacorallia) // Zoologische Mededelingen, Leiden. Vol.345. P.367386.

Rodríguez E., López-González P.J. 2008. The gastropodsymbiotic sea anemone genus Isosicyonis Carlgren, 1927 (Actiniaria: Actiniidae): a new species from the Weddell Sea (Antarctica) that clarifies the taxonomic position of the genus // Scientia Marina. Vol.72. No.1. P.73-86.

Rodríguez E., López-González P.J. 2013. New records of Antarctic and Sub-Antarctic sea anemones (Cnidaria, Anthozoa, Actiniaria and Corallimorpharia) from the Weddell Sea, Antarctic Peninsula, and Scotia Arc // Zootaxa. Vol.3624. No.1. P.1-100.

Roule L. 1909. Hexactinides. Expedition Antarctic française 1903-1905 commandée par le Dr. Jean Charcot. Paris: Masson Editeurs. P.1-19.

Sanamyan N. 2001. New and poorly known Actiniaria from the NW Pacific // Zoosystematica Rossica. Vol.9 (for 2000). No.1. P.1-10. 
Sanamyan N., Sanamyan K. 2012. Edwardsia sojabio sp. n. (Cnidaria: Anthozoa: Actiniaria: Edwardsiidae), a new abyssal sea anemone from the Sea of Japan // Deep-SeaResearch II. Vol.86-87. P.225-230.

Sanamyan N., Sanamyan K., Tabachnick K. 2012. The first species of Actiniaria, Spongiactis japonica gen.n., sp.n. (Cnidaria: Anthozoa) an obligate symbiont of a glass sponge // Invertebrate Zoology. Vol.9. No.2. P.127-141.

Sanamyan N., Sanamyan K., McDaniel N. 2013. Two new shallow water sea anemones of the family Actiniidae (Cnidaria: Anthozoa: Actiniaria) from British Columbia (NE Pacific) // Invertebrate Zoology. Vol.10. No.2. P.199-216.

Schmidt H. 1969. Die Nesselkapseln der Aktinien und ihre differentialdiagnostische Bedeutung // Helgoländer wissenschaftliche Meeresuntersuchungen. Bd.19. S.284-317.

Schmidt H. 1972a. Prodromus zu einer Monographie der mediterranean Aktinien // Zoologica. Bd.121. S.1-146.

Schmidt H. 1972b. Die Nesselkapseln der Anthozoen und ihre Bedeutung für die phylogenetische Systematik // Helgoländer wissenschaftliche Meeresuntersuchungen. Bd.23. S.422-458.

Schmidt H. 1974. On evolution in the Anthozoa // Proceedings of the Second International Coral Reef Symposium 1. Brisbane: Great Barrier Reef Committee. P.533-560.

Schories D., Niedzwiedz G. 2012. Precision, accuracy and application of diver towed underwater GPS receivers
//Environmental Monitoring and Assessment. Vol.184. No.4. P.2359-2372.

Stephenson T.A. 1918. Coelenterata Pt.1 Actiniaria // Natural History Report of British Antarctic ('Terra Nova') Expedition, 1910. Zology. Vol.5. No.1. P.168.

Stephenson T.A. 1920. On the classification of Actiniaria 1.- Forms with acontia and forms with a mesogloeal sphincter // Quarterly Journal of Microscopical Science. Vol.64. No.4. P.425-574.

Stephenson T.A. 1928. The British sea anemones. London: Ray Society. Vol.1. P.1-148.

Studer T. 1879. Zweite Abtheilung der Anthozoa polyactinia, welche während der Reise S.M.S. Corvette Gazelle um die Erde gesammelt wurden // Monatsberichte der Königlichen Preussischen Akademie der Wissenschaften zu Berlin. Bd.25. S.524-550.

Torrey H.B. 1902. Papers from the Harriman Alaska Expedition. XXX. Anemones, with discussion of variation in Metridium // Proceedings of the Washington Academy of Sciences. Vol.4. P.373-410.

Verrill A.E. 1922. Alcyonaria and Actiniaria // Report of the Canadian Arctic Expedition, 1913-1918. Vol.8. Part G. P.1-165.

Williams R.B. 1981. A sea anemone Edwardsia meridionalis sp.n., from Antarctica and a preliminary revision of the genus Edwardsia de Quatrefages, 1841 (Coelenterata: Actiniaria) // Records of the Australian Museum. Vol.33. P.325-360.

Responsible editor E.N. Temereva 